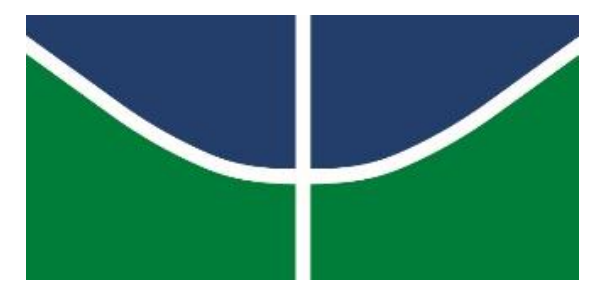

UNIVERSIDADE DE BRASÍLIA (UNB)

INSTITUTO DE QUÍMICA (IQ)

PROGRAMA DE PÓS-GRADUAÇÃO EM QUÍMICA (PPGQ)

LABORATÓRIO DE MATERIAIS E COMBUSTÍVEIS (LMC)

DISSERTAÇÃO DE MESTRADO

\title{
NITRATOS ORGÂNICOS GRAXOS: SÍNTESE E AVALIAÇÃO PARA APLICAÇÃO COMO ADITIVO MULTIFUNCIONAL PARA BIODIESEL
}

\section{Thayana Felipe Lelis dos Santos}

Orientador: Prof. Dr. Paulo Anelmo Ziani Suarez

Coorientador: Prof. Dr. Wender Alves da Silva 
Thayana Felipe Lelis dos Santos

\section{NITRATOS ORGÂNICOS GRAXOS: SÍNTESE E AVALIAÇÃO PARA APLICAÇÃO COMO ADITIVO MULTIFUNCIONAL PARA BIODIESEL.}

Dissertação de Mestrado, apresentada ao Programa de Pós Graduação em Química da Universidade de Brasília (UnB), como um dos requisitos legais para obtenção do Grau de Mestra em Química.

Orientador: Prof. Dr. Paulo Anselmo Z. Suarez.

Co-orientador: Prof. Dr. Wender Alves da Silva.

Brasília, 15 de dezembro de 2016 


\section{FOLHA DE APROVAÇÃO}

Comunicamos a aprovação da Defesa de Dissertação de Mestrado do (a) aluno (a) Thayana Felipe Lelis dos Santos, matrícula no 14/0199217, intitulada "Nitratos Orgânicos Graxos: Síntese e Avaliação para Aplicação como Aditivo Multifuncional para Biodiesel", apresentada no (a) Auditório Prof. Lauro Morhy do Instituto de Química (IQ) da Universidade de Brasília (UnB) em 15 de dezembro de 2016.

Prof. Dr. Paulo Anselmo Ziani Suarez Presidente de Banca (IQ/UnB)

Prof.a Dra. Vanda Maria de Oliveira Membro Titular (UCB)

Prof. Dr. Angelo Henrique de Lira Machado Membro Titular (IQ/UnB)

Prof. Dr. Fábio Moreira da Silva Membro Suplente (IQ/UnB)

Em 15 de dezembro de 2016. 
"A chance de dar tudo errado era tudo que eu tinha em mim, mas olha o que Ele fez comigo..."

Thalles Roberto 
A José Carlos e Cleonice Lelis, com todo amor, gratidão $e$ reconhecimento, pois eles me fizeram ser quem sou hoje, com muito amor, esforço e dedicação. 


\section{AGRADECIMENTOS}

Ao Senhor Deus por me dar a oportunidade de realizar meus sonhos, pelo dom de celebrar a vida, por fazer o sol brilhar todas as manhãs só pra me dar uma nova oportunidade a cada dia e por sempre me renovar as forças, mesmo quando não as mereço!

A meus pais José Carlos e Cleonice Lelis pelo amor, dedicação e apoio incondicional, mesmo quando não concordavam, nem tampouco entendiam meus motivos, sonhos e

objetivos. À tia Ana Leles pela amizade, companheirismo e cumplicidade. A meu irmão Thamerson Felipe Lelis por sempre acreditar em mim e ao sobrinho Carlos Emanuel Lelis pelo amor mais puro e inocente que já conheci e por se tornar um importante motivo para prosseguir sempre!

Aos amigos Renato Santana, Ingryd Medeiros, Francisco Cleudio e Karolyne Vilela que tornaram a rotina infinitamente mais divertida e gratificante, através da amizade, companheirismo e cumplicidade. Ao Fernando Rocha, em especial, cuja parceria me foi imposta, entretanto, se tornou muito mais que um grande amigo, um irmão!

Ao professor Paulo Suarez por acreditar em mim e me dar uma oportunidade sem ao menos conhecer-me. Ao professor Wender Silva pela co-orientação. Aos professores Fábio Silva, Ângelo Machado e Vanda Oliveira por aceitarem compor a banca e pelas valiosas contribuições.

Aos meus alunos por serem importantes motivos e incentivos para buscar melhor qualificação.

Aos colegas do Laboratório de Materiais e Combustíveis (LMC) pelos diversos momentos de cooperação, discussões e descontração. Especialmente ao David Mark, Yuri Falcão e ao Marcelo Rodrigues pela ajuda constante no desenvolvimento do trabalho.

À Dra. Ellen Rangel pela realização dos inúmeros ensaios microbiológicos além do contagiante bom humor de sempre, e claro, à sua amizade direcionada a mim. Ao Luiz Felipe e à ANP pela realização dos testes de número de cetano derivado. Ao Eduardo Ulisses pela realização dos espectros de Ressonância Magnética Nuclear de Carbono e Hidrogênio. 


\section{LISTA DE TABELAS}

Tabela 1: Produtos e intermediários esperados. Onde R corresponde ao restante de átomos de carbono para completar uma cadeia com 18 carbonos, contando a partir da carbonila. FONTE: Próprio autor.

Tabela 2: Taxa de conversão do biodiesel metílico de oliva, canola, mamona e soja, respectivamente. FONTE: Próprio autor.

Tabela 3:Conversão dos produtos epóxidados. FONTE: Próprio autor. 54

Tabela 4: Deslocamento químico dos hidrogênios, obtidos por meio dos espectros de ${ }^{1} \mathrm{HRMN}$. FONTE: Próprio autor. 62

Tabela 5: Deslocamento químico dos carbonos, obtidos por meio dos espectros de ${ }^{13} \mathrm{CRMN}$. FONTE: Próprio autor. 65

Tabela 6: Número de cetano de nitroderivados.. FONTE: Próprio autor. 66

Tabela 7: Resultados dos ensaios microbiológicos frente à fungos e bactérias. FONTE: Próprio autor. 68

Tabela 8: Tempo de oxidação de alguns dos nitrocompostos na concentração de $100 \%$. FONTE: Próprio autor 70

Tabela 9: Resultado dos testes físico-químicos. FONTE: Próprio autor. 76 


\section{LISTA DE FIGURAS}

Figura 1: Obtenção de combustíveis, planejados a partir de triacilglicerídeos pelas reações de (a) Craqueamento e (b) Transesterificação. Equações não balanceadas. (Suarez, et. al, 2007 -

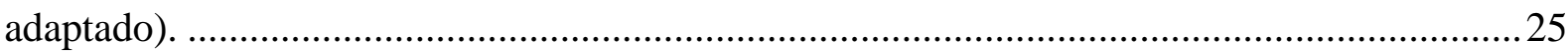

Figura 2: Fotografias de produto formado a partir da oxidação, auto-oxidação e contaminação microbiológica do biodiesel. FONTE: Posto Ipiranga e Petrobrás (2010); Zimmeret. al. 2011

Figura 5: Fotografia das placas de ensaio. A, B e C frente ao fungo. D, E e F frente a bactéria. FONTE: Próprio autor. 


\section{LISTA DE ESQUEMAS}

Esquema 1: Transesterificação de triacilglicerídeos. (Oliveira, 2013).

Esquema 2: Representação genérica da reação de epoxidação. FONTE: (Pedrozo, et. al. 2009adaptado) Erro! Indicador não definido.

Esquema 3: Representação genérica da reação de hidrólise e solvólise. FONTE: (Biggs,1971) Erro! Indicador não definido.

Esquema 4:Reação genérica de esterificação. FONTE: Prórpio autor 37

Esquema 5: Reação genérica de otenção dos primeiros nitro-derivados alvo. FONTE: Próprio autor.

Esquema 6: Reação genérica de obtenção dos epóxidos de éster metílico. FONTE: Próprio autor.

Esquema 7: Reação genérica de obtenção dos compostos hidroxilados. FONTE: Próprio autor.

Esquema 8: Reação genérica de obtenção dos compostos metoxilados. FONTE: Próprio autor.

Esquema 9: Reações genéricas para a obtenção dos nitratos advindos de produtos hidroxilados ou metoxilados. FONTE: Próprio autor.

Esquema 10:Esquema genérico de prováveis produtos obtidos pela reação de hidrólise. FONTE: Próprio autor.

Esquema 11: Esquema genérico de prováveis produtos obtidos pela reação de solvólise. FONTE: Próprio autor. 56

Esquema 12: Esquema genérico de prováveis produtos obtidos pela reação de nitração de intermediários derivados dos respectivos ésteres metílicos. FONTE: Próprio autor. 57

Esquema 13: Estrutura geral para análise das Tabelas de deslocamento químico. FONTE: Próprio autor. 58 


\section{LISTA DE ANEXOS}

Anexo 1: Espectros de Infra-vermeho de alguns derivados do azeite de oliva, são eles os compostos: $1,7,9,33$ e 35 .

Anexo 2: Espectros de Infra-vermeho de alguns derivados do azeite de oliva, são eles os compostos: 5, 17, 21, 25, 29 e 31. FONTE: Próprio autor.

Anexo 3: Espectros de Infra-vermeho de alguns derivados do óleo de canola, são eles os compostos: 2, 8, 10, 34 e 36. FONTE: Próprio autor.

Anexo 4: Espectros de Infra-vermeho de alguns derivados do óleo de canola, são eles os compostos: 6, 18, 22, 26, 30 e 32. FONTE: Próprio autor.

Anexo 5: Espectros de Infra-vermeho de alguns derivados do óleo de mamona, são eles os compostos: 3, 12, 13, 40 e 41. FONTE: Próprio autor.

Anexo 6: Espectros de Infra-vermeho de alguns derivados do óleo de mamona, são eles os compostos: 11, 19, 23, 27, 38, 37 e 39. FONTE: Próprio autor.

Anexo 7: Espectros de Infra-vermeho de alguns derivados do óleo de soja, são eles os compostos: 4, 15, 16, 44 e 45. FONTE: Próprio autor.

Anexo 8: Espectros de Infra-vermeho de alguns derivados do óleo de soja, são eles os compostos: 14, 20, 24, 28, 42 e 43. FONTE: Próprio autor.

Anexo 9: Espectro de ressonância magnética nuclear de hidrogênio ( ${ }^{1} \mathrm{H}$ RMN) do composto número 6. FONTE: Próprio autor.

Anexo 10: Espectro de ressonância magnética nuclear de carbono $\left({ }^{13} \mathrm{C} \mathrm{RMN}\right)$ do composto número 6. FONTE: Próprio autor.

Anexo 11: Espectro de ressonância magnética nuclear de hidrogênio ( ${ }^{1} \mathrm{H}$ RMN) do composto número 7. FONTE: Próprio autor.

Anexo 12: Espectro de ressonância magnética nuclear de carbono $\left({ }^{13} \mathrm{C} \mathrm{RMN}\right)$ do composto número 7. FONTE: Próprio autor.

Anexo 13: Espectro de ressonância magnética nuclear de hidrogênio $\left({ }^{1} \mathrm{H}\right.$ RMN) do composto número 9. FONTE: Próprio autor.

Anexo 14: Espectro de ressonância magnética nuclear de carbono $\left({ }^{13} \mathrm{C} \mathrm{RMN}\right)$ do composto número 9. FONTE: Próprio autor. 100

Anexo 15: Espectro de ressonância magnética nuclear de hidrogênio ( ${ }^{1} \mathrm{H}$ RMN) do composto número 11. FONTE: Próprio autor. 
Anexo 16: Espectro de ressonância magnética nuclear de carbono $\left({ }^{13} \mathrm{C} \mathrm{RMN}\right)$ do composto número 11. FONTE: Próprio autor.

Anexo 17: Espectro de ressonância magnética nuclear de hidrogênio (1H RMN) do composto número 12. FONTE: Próprio autor.

Anexo 18: Espectro de ressonância magnética nuclear de carbono $\left({ }^{13} \mathrm{C} \mathrm{RMN}\right)$ do composto número 12. FONTE: Próprio autor. 104

Anexo 19: Espectro de ressonância magnética nuclear de hidrogênio ( $\left.{ }^{1} \mathrm{H} \mathrm{RMN}\right)$ do composto número 13. FONTE: Próprio autor. 105

Anexo 20: Espectro de ressonância magnética nuclear de hidrogênio $\left({ }^{1} \mathrm{H} \mathrm{RMN}\right)$ do composto número 14. FONTE: Próprio autor. 106

Anexo 21: Espectro de ressonância magnética nuclear de carbono $\left({ }^{13} \mathrm{C} \mathrm{RMN}\right)$ do composto número 14. FONTE: Próprio autor. 107

Anexo 22: Espectro de ressonância magnética nuclear de hidrogênio $\left({ }^{1} \mathrm{H}\right.$ RMN) do composto número 16. FONTE: Próprio autor. 108

Anexo 23: Espectro de ressonância magnética nuclear de carbono $\left({ }^{13} \mathrm{C} \mathrm{RMN}\right)$ do composto número 16. FONTE: Próprio autor.

Anexo 24: Espectro de ressonância magnética nuclear de hidrogênio ( $\left({ }^{1} \mathrm{H} \mathrm{RMN}\right)$ do composto número 17. FONTE: Próprio autor.

Anexo 25: Espectro de ressonância magnética nuclear de carbono $\left({ }^{13} \mathrm{C} \mathrm{RMN}\right)$ do composto número 17. FONTE: Próprio autor.

Anexo 26: Espectro de ressonância magnética nuclear de hidrogênio ( ${ }^{1} \mathrm{H}$ RMN) do composto número 18. FONTE: Próprio autor.

Anexo 27: Espectro de ressonância magnética nuclear de carbono $\left({ }^{13} \mathrm{C} \mathrm{RMN}\right)$ do composto número 18. FONTE: Próprio autor. 113

Anexo 28: Espectro de ressonância magnética nuclear de hidrogênio $\left({ }^{1} \mathrm{H} \mathrm{RMN}\right)$ do composto número 19. FONTE: Próprio autor. 114

Anexo 29: Espectro de ressonância magnética nuclear de carbono $\left({ }^{13} \mathrm{C} \mathrm{RMN}\right)$ do composto número 19. FONTE: Próprio autor. 115

Anexo 30: Espectro de ressonância magnética nuclear de hidrogênio $\left({ }^{1} \mathrm{H} \mathrm{RMN}\right)$ do composto número 20. FONTE: Próprio autor. 116

Anexo 31: Espectro de ressonância magnética nuclear de carbono $\left({ }^{13} \mathrm{C} \mathrm{RMN}\right)$ do composto número 20. FONTE: Próprio autor. 
Anexo 32: Espectro de ressonância magnética nuclear de hidrogênio $\left({ }^{1} \mathrm{H} \mathrm{RMN}\right)$ do composto número 22. FONTE: Próprio autor.

Anexo 33: Espectro de ressonância magnética nuclear de carbono $\left({ }^{13} \mathrm{C} \mathrm{RMN}\right)$ do composto número 22. FONTE: Próprio autor.

Anexo 34: Espectro de ressonância magnética nuclear de hidrogênio ( $\left.{ }^{1} \mathrm{H} \mathrm{RMN}\right)$ do composto número 23. FONTE: Próprio autor.

Anexo 35: Espectro de ressonância magnética nuclear de hidrogênio ( $\left.{ }^{1} \mathrm{H} \mathrm{RMN}\right)$ do composto número 25. FONTE: Próprio autor.

Anexo 36: Espectro de ressonância magnética nuclear de carbono $\left({ }^{13} \mathrm{C} \mathrm{RMN}\right)$ do composto número 25. FONTE: Próprio autor.

Anexo 37: Espectro de ressonância magnética nuclear de hidrogênio ( ${ }^{1} \mathrm{H}$ RMN) do composto número 26. FONTE: Próprio autor.

Anexo 38: Espectro de ressonância magnética nuclear de carbono $\left({ }^{13} \mathrm{C} \mathrm{RMN}\right)$ do composto número 26. FONTE: Próprio autor.

Anexo 39: Espectro de ressonância magnética nuclear de hidrogênio ( ${ }^{1} \mathrm{H}$ RMN) do composto número 42. FONTE: Próprio autor.

Anexo 40: Espectro de ressonância magnética nuclear de carbono $\left({ }^{13} \mathrm{C} \mathrm{RMN}\right)$ do composto número 42. FONTE: Próprio autor.

Anexo 41: Espectro de ressonância magnética nuclear de hidrogênio $\left({ }^{1} \mathrm{H} \mathrm{RMN}\right)$ do composto número 43. FONTE: Próprio autor.

Anexo 42: Espectro de ressonância magnética nuclear de carbono $\left({ }^{13} \mathrm{C} \mathrm{RMN}\right)$ do composto número 43. FONTE: Próprio autor.

Anexo 43:Espectro de ressonância magnética nuclear de hidrogênio ( $\left.{ }^{1} \mathrm{H} \mathrm{RMN}\right)$ do composto número 44. FONTE: Próprio autor.

Anexo 44: Espectro de ressonância magnética nuclear de carbono $\left({ }^{13} \mathrm{C} \mathrm{RMN}\right)$ do composto número 44. FONTE: Próprio autor. 130

Anexo 45: Espectro de ressonância magnética nuclear de hidrogênio ( ${ }^{1} \mathrm{H}$ RMN) do composto número 45. FONTE: Próprio autor.

Anexo 46: Espectro de ressonância magnética nuclear de carbono $\left({ }^{13} \mathrm{C} \mathrm{RMN}\right)$ do composto número 45. FONTE: Próprio autor. 


\section{RESUMO}

O aumento da demanda energética vem provocando ao longo do tempo a ampliação da utilização de combustíveis de origem fóssil e, consequentemente, o incremento dos problemas de cunho ambiental. Neste sentido, nitratos orgânicos constituem uma alternativa interessante do ponto de vista econômico, social e ambiental. Tais insumos foram planejados a partir de fontes de origem renovável (biomassa), não comprometendo, portanto, o selo de combustível verde do biodiesel. São obtidos em geral, de maneira eficiente com baixos custos agregados, visando à aplicação como aditivos multifuncionais para biodieselcumprindo, inclusive as exigências físico-químicas estabelecidas pela Agência Nacional de Petróleo (ANP). No geral, os nitrocompostos mostraram-se excelentes melhoradores do índice de cetano, de modo que $60 \%$ dos produtos testados revelaram significativa melhora. Dispondo-se dos ensaios microbiológicos, frente a fungos e bactérias, alguns dos produtos alvo deste trabalho revelaram potencial fungicida, exibindo halos de inibição que variaram de 10 a $25 \mathrm{~mm}$.

Palavras Chave: Biodiesel, Nitrocompostos, Aditivos multifuncionais, Melhoradores de cetano, Antioxidantes, Antimicrobianos. 


\begin{abstract}
The increasing world energy demand has led to a massive use of fossil fuels and, consequently, bringing environmental problems and high energy prices. In this sense, organic nitrates products constitute an interesting economic, social and environmental alternative to this fuels. These inputs were planned from renewable sources (biomass), thus not compromising the biodiesel green fuel seal. They are generally obtained efficiently with low aggregate costs, aiming at the application as multifunctional additives for biodiesel fulfilling, including the physico-chemical requirements established by the National Petroleum Agency (ANP). In general, the nitrocomposites proved to be excellent cetane index improvers, so that $60 \%$ of the tested products showed significant improvement. In microbiological assays, against fungi and bacteria, some of the target products of this work revealed fungicidal potential, exhibiting inhibition halos on plate ranging from 10 to $25 \mathrm{~mm}$.
\end{abstract}

Keyword: Biodiesel, Nitrocompounds, Multifunctionals additive, Cetane improvers, Antioxidant, Antimicrobials. 


\section{SUMÁRIO}

1. INTRODUÇÃO GERAL 19

2. OBJETIVOS 22

3. REVISÃO BIBLIOGRÁFICA 24

3.1 A Biomassa Brasileira: Alternativa Para Substituir Combustíveis De Origem Petroquímica 24

3.2 Biodiesel 25

3.2.1 Utilização de óleos e gorduras na produção de biodiesel

3.2.2 O Programa de Nacional de Produção e Uso de Biodiesel (PNPB) 26

3.2.3 Algumas oleaginosas 27

3.2.4 Problematização $\quad 28$

3.2.4.1 Instabilidade Oxidativa 29

3.2.4.2 Suscetibilidade à Contaminação Microbiana

3.2.4.3 Número de Cetano 30

3.3 Utilização De Nitrocompostos Graxos Em Biodiesel 30

4. METODOLOGIA SINTÉTICA Erro! Indicador não definido.

4.1 Reação de Transesterificação Erro! Indicador não definido.

4.2 Reação de Epoxidação Erro! Indicador não definido.

4.3 Reação de Solvólise e Hidrólise Erro! Indicador não definido.

4.4 Reação de nitração $\quad$ Erro! Indicador não definido.

5. PARTE EXPERIMENTAL 33

5.1. METODOLOGIAS SINTÉTICAS 35 
5.1.1. Transesterificação do óleo vegetal, para a obtenção do biodiesel. 35

5.1.1.1. Transesterificação do óleo vegetal, para a obtenção do biodiesel metílico.

5.1.1.2 Transesterificação do óleo vegetal, para a obtenção do biodiesel derivado do etilenoglicol e glicerina. $\quad 38$

5.1.2 Nitração do biodiesel derivado do etilenoglicol e glicerina, para obtenção dos primeiros nitro-derivados. $\quad 38$

5.1.3 Epoxidação de biodiesel. $\quad 40$

5.1.4 Abertura do epóxido: Hidrólise. $\quad 42$

5.1.5 Abertura do epóxido: Solvólise $\quad 43$

5.1.6 Nitração dos produtos hidroxilados e metoxilados. $\quad 44$

5.2. Metodologia Dos Testes Biológicos 44

5.2.1 Preparação do meio de superfície com ágar $\quad 45$

5.2.2 Preparação do meio de cultura 45

5.2.3 Preparação das placas de ensaio $\quad 45$

5.3 Caracterização Dos Produtos E Intermediários 46

5.4 Estabilidade Oxidativa 47

5.5 Viscosidade e Densidade 47

5.6 Número De Cetano Derivado 47

6. RESULTADOS E DISCUSSÃO 49

6.1 Aspectos Visuais Gerais 49

6.2 Caracterização De Biodiesel 49

6.2.1 Cromatografia Líquida de Alto Desempenho (HPLC) 49

6.2.2 Espectroscopia na região do Infra-vermelho (IV) 50 
6.2.3 Espectroscopia de Ressonância Magnética (RMN) 52

6.2.3.1 Caracterização dos ésteres de partida $\quad 52$

6.2.3.2 Caracterização dos intermediários epoxidados 53

6.2.3.3 Caracterização dos intermediários hidrolisados 54

6.2.3.4 Caracterização dos intermediários solvolisados 55

6.2.3.5 Caracterização dos produtos alvo 56

6.4 Avaliações de Número de Cetano Derivado 66

6.5 Avaliações Microbiológicas 67

6.6 Testes de Estabilidade à Oxidação 69

6.7 Caracterização Físico-Química70

7- CONCLUSÕES E PERSPECTIVAS 78

8.REFERENCIAL BIBLIOGRÁFICO 80

9. ANEXOS 85 


\section{INTRODUÇÃO GERAL}




\section{INTRODUÇÃO GERAL}

Em um mundo globalizado, onde predomina essencialmente o modelo capitalista de desenvolvimento econômico-financeiro, implantado em âmbito nacional e mundial, evidencia-se cada vez mais o avanço de novas e poderosas tecnologias. (Pinto, et. al. 2015). Conseqüentemente, com a capacidade de aquisição de bens e serviços, aumenta-se a procura por fontes energéticas, supridas basicamente por substâncias formadas de carbono e hidrogênio. No geral, tais fontes de energia advém de recursos naturais não-renováveis cuja queima provoca a liberação de dióxido de carbono, um gás altamente poluente que causa danos ao ser humano, como problemas respiratórios.

Nesse contexto, a busca por fontes energéticas de origem renovável e menos poluentes tem se tornado cada vez mais necessária, sendo assim, a utilização de biodiesel tem ganhado um merecido destaque nesse cenário. O biodiesel é um combustível biodegradável oriundo de óleos vegetais, tendo este demonstrado importantíssima contribuição para a melhoria da qualidade ambiental, respeitando inclusive as exigências do Protocolo de Kyoto e às emissões de Gases de Efeito Estufa (GEE). A produção deste biocombustível possibilita ainda a inserção de novos mercados, além de agregar valores a matérias-primas diminuindo assim os custos com importação de óleos vegetais e óleo diesel refinado, além de gerar empregos no setor industrial e agrícola. (Genovesei, et. al. 2006; Faria,et. al. 2010)

Por se tratar do maior país em extensão territorial de todo o Hemisfério Sul e América Latina, o Brasil apresenta grande diferencial em relação a outros países, no quesito biodiversidade. Assim, as incontáveis espécies vegetais contidas em território nacional podem ser usadas como matéria prima para suprir a demanda energética. Podem ainda ser usadas para o desenvolvimento e a otimização de novos combustíveis "verdes". Tais obtenções se dão de maneira eficiente, com baixo custo agregado, além de serem considerados ecologicamente corretos, por se tratar de uma fonte de energia de origem renovável. (Genovesei, et. al. 2006; Pacheco et. al. 2006).

Assim, o Governo Federal instituiu em 2004 o Programa Nacional de Produção e uso do Biodiesel (PNPB), objetivando a introdução do biodiesel na matriz energética do Brasil. Tal proposta consiste em uma parceria público-privado que objetiva o incentivo para a produção e uso de biodiesel. Atualmente, a legislação vigente estabelecida pela Agência 
Nacional de Petróleo prevê que todo diesel comercializado em território nacional seja misturado com $7 \%$ de biodiesel, e, em longo prazo prevê que o combustível de origem fóssil seja substituído em até 20\%. (Ministério de Minas e Energia e Agência Nacional de Petróleo, 2015).

Apesar das inúmeras vantagens que oferece, o biodiesel enfrenta uma problemática relacionada à instabilidade oxidativa. A reatividade da molécula de biodiesel pode conduzi-lo a modificações moleculares indesejáveis. Tais modificações podem levar a uma diminuição do ponto de fulgor e aumento da acidez, respectivamente, conduzindo o produto a desrespeitar as especificações estabelecidas pelo órgão competente, tornando-o inutilizado para seu devido fim, já que os produtos de oxidação podem causar uma serie de problemas ao motor e à vida útil do veículo. (Nunes, 2015; Dunn e Knothe, 2003).

Outra problemática associada ao uso de biodiesel é a sua alta sensibilidade à contaminação microbiana, que compromete a qualidade do combustível, diminuindo assim o período de armazenamento e o prazo de validade do mesmo. O crescimento microbiano pode levar ainda, ao bloqueio de gasodutos e filtros, gerando portanto, uma preocupação para produtores, fornecedores e consumidores. (Maria, at. al. 2009; Ndana, et. al. 2012; Bento, et. al. 2004).

A fim de solucionar esses problemas, tem-se visto um aumento no emprego de aditivos antimicrobianos e antioxidantes na composição do biodiesel. Entretanto, apesar de apresentar bons resultados quanto a ações antioxidante e antimicrobianas, o emprego de tais aditivos em sua grande maioria comprometem o "selo de combustível verde" do biocombustível, além de provocar um aumento do custo agregado do mesmo. Sendo assim é de extrema importância estudos que visem à obtenção de aditivos que atuem de maneira eficiente sem comprometer a qualidade do biocombustível.

Neste sentido, o presente trabalho visa à produção e caracterização de nitratos orgânicos planejados a partir de óleos vegetais, almejando a obtenção de aditivos multifuncionais que atuem de maneira eficiente como anti-microbianos, antioxidantes e melhoradores de número de cetano. A obtenção destes por meio de uma fonte renovável foi pensada com a finalidade de que os mesmo não comprometam as definições de combustível verde do biodiesel, com garantia de qualidade e baixíssimo custo agregado à sua produção. 
OBJETIVOS 


\section{OBJETIVOS}

O presente trabalho tem como principal objetivo as modificações químicas de óleos vegetais, visando a produção de nitratos orgânicos graxos, por meio da funcionalização das insaturações e grupamentos terminais reativos. A fim de obter-se produtos com propriedades melhoradoras de número de cetano, anti-microbiológicas e anti-oxidantes, contemplados em um mesmo composto.

Como objetivos específicos foram estabelecidos os seguintes:

1. Estabelecer uma rota sintética eficiente para obtenção de nitrocompostos orgânicos derivados de ésteres de ácidos graxos;

2. Caracterizar a estrutura química dos produtos finais e intermediários;

3. Avaliar as propriedades físico-químicas dos nitrocompostos;

4. Delimitar a potencial atividade biológica das blendas de nitrocompostos e biodiesel;

5. Aferir a estabilidade oxidativa das blendas de nitrocompostos e biodiesel;

6. Avaliar o número de cetano de blendas de nitrocompostos e biodiesel. 
REVISÃO BIBLIOGRÁFICA 


\section{REVISÃO BIBLIOGRÁFICA}

\subsection{A Biomassa Brasileira: Alternativa Para Substituir Combustíveis De Origem Petroquímica}

As fontes energéticas podem ser classificadas como não-renováveis (temporárias) e renováveis (permanentes). O petróleo, principal representante dos combustíveis líquidos temporários apresenta uma taxa de formação muito inferior em relação à sua utilização, fazendo com que o custo deste produto se eleve cada vez mais, podendo, ainda, um dia chegar ao esgotamento. Já os combustíveis líquidos de fontes renováveis utilizam como matériaprima a biomassa, que são consideradas inesgotáveis, tendo em vista que podem ser replantados. (Leite, et. al. 2013).

O Brasil, por ser o maior país em extensão territorial de todo o Hemisfério Sul e da América Latina, apresenta grande diferencial em relação a outros países no quesito biodiversidade, permitindo a geração de fontes de energia renováveis, bem como o desenvolvimento e a busca pela otimização de novos combustíveis "verdes" oriundos da biomassa, que supram ainda a demanda interna do país, em caso de escassez de combustíveis fósseis.(Genovesei, et. al. 2006; Pacheco, et. al. 2005)

O uso de óleos oriundos da biomassa como combustível começou a ser explorado por Rudolph Diesel no fim do século XIX, quando realizou testes com combustíveis distintos em motor a combustão interna. Entretanto, seus estudos não receberam grande atenção, já que na época havia abundancia e baixíssimo custo agregado ao petróleo. Apenas nas décadas de 1970 e1990, durante as crises mundiais na indústria petrolífera, aliada ao aumento da demanda energética e a preocupação ambiental, que surgiu a necessidade da produção de alternativas renováveis para a produção de combustíveis, como por exemplo, o biodiesel. (Suarez, et. al. 2005; Oliveira, et. al. 2008). 


\subsection{Biodiesel}

\subsubsection{Utilização de óleos e gorduras na produção de biodiesel}

Os óleos e gorduras vegetais ou animais são constituídos por moléculas conhecidas como ácidos graxos, usualmente esterificados com glicerol. Dependendo da proporção em que o glicerol encontra-se esterificado, podem estar presentes mono, di ou triacilglicerídeos, além de pequenas quantidades de ácidos graxos livres. No geral, os ácidos graxos possuem de 4 a 24 átomos de carbono e até 3 insaturações em sua estrutura, o que irá determinar a reatividade química e as propriedades físico-químicas desses compostos. (Martins, et. al. 2013)

Durante o período da Segunda Guerra Mundial, dois processos foram estudados a fim de transformar óleos e gorduras em combustíveis líquidos: o craqueamento e a transesterificação. O primeiro ocorre em altas temperaturas, na presença ou não de catalisador. Esta transformação provoca o rompimento das moléculas de triacilgicerídeos, levando à formação de uma mistura de hidrocarbonetos e compostos oxigenados, além de monóxido de carbono e água, como é possível observar na reação a representada na Figura 1.

Já a transesterificação, envolve a reação do triacilglicerídeo com álcoois de cadeias curtas, na presença de um catalisador ácido ou básico, fornecendo, como produto desta reação, monoésteres de ácidos graxos. A reação b, observada na Figura 1, foi realizada com etanol e metanol.(Suarez, et. al. 2007).

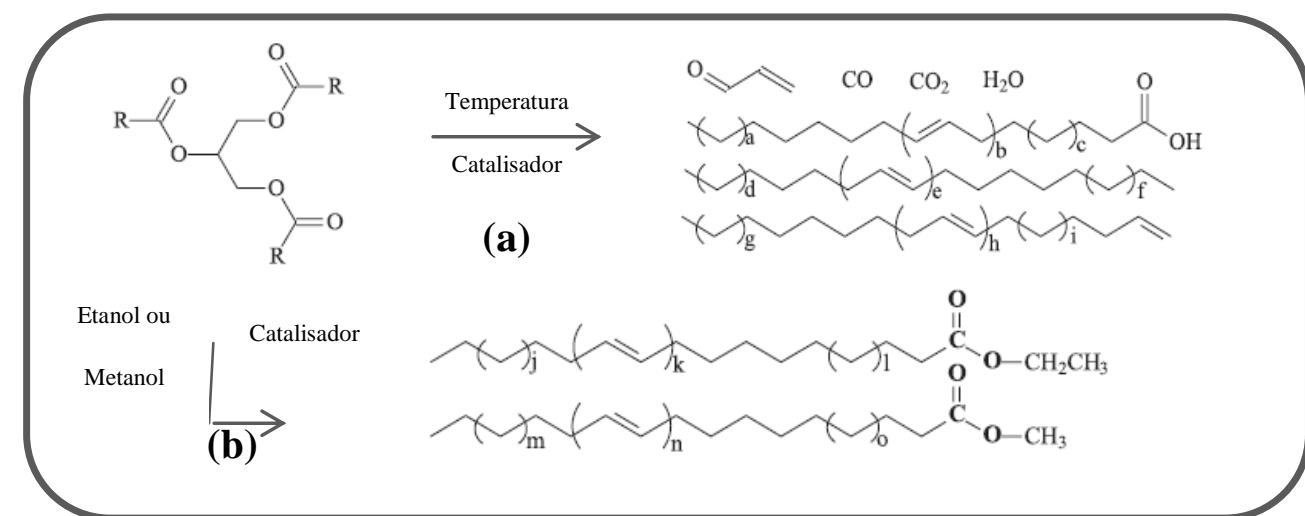

Figura 1: Obtenção de combustíveis, planejados a partir de triacilglicerídeos pelas reações de (a) Craqueamento e (b) Transesterificação. Equações não balanceadas. (Suarez, et. al, 2007 - adaptado). 
Assim, a Lei $\mathrm{n}^{\circ} 1197$ de 13 de janeiro de 2005 define que biodiesel é um combustível derivado de biomassa para uso em motores a combustão interna com ignição por compressão, que possibilita substituir parcial ou totalmente o óleo diesel de origem fóssil. A Agencia Nacional de Petróleo (ANP) define como, combustível composto de alquil ésteres de ácidos carboxílicos de cadeia longa, produzido a partir da transesterificação e/ou esterificação de material graxo, de origem animal ou vegetal, que atenda a legislação vigente. (ANP, 2014).

\subsubsection{O Programa de Nacional de Produção e Uso de Biodiesel (PNPB)}

O Programa Nacional de Produção e uso do Biodiesel (PNPB) foi lançado pelo Governo Federal em dezembro de 2004, objetivando a introdução do biodiesel na matriz energética do Brasil. A iniciativa consiste na parceria público-privada, aportando-se recursos e investimentos na distribuição, pesquisa e produção de matérias-primas, através da definição de metas para as mesmas. (Min. Minas e Energ. 2015 e ANP, 2015).

O Governo Federal determinou que a partir de 2008 todo óleo diesel comercializado em território nacional constituísse um acréscimo de biodiesel (B100). Entre janeiro e junho de 2008 esta mistura foi de $2 \%$ de biodiesel (v/v), esta percentagem foi aumentando gradativamente ao longo do tempo, de modo que atualmente (desde novembro de 2014) passou a ser de 7\% (v/v), conforme Lei 13.033/2014. Em longo prazo prevê-se que o combustível fóssil deva ser substituído em até $20 \%$ pelo biocombustível.

O desenvolvimento da produção de biodiesel tem se mostrado significativo, levandose em consideração que, segundo a ANP, até o mês de julho de 2016 o Brasil produziu 2.140.689 $\mathrm{m}^{3}$ do referido biocombustível (B100), cerca de 3,1\% a menos em comparação com o mesmo período do ano de 2015. (ANP, 2015). Tal demanda contribui de diversas maneiras para o crescimento econômico e social do país, entre elas: aumento da geração de empregos no campo e indústria, melhora da qualidade do ar, diminuindo assim o índice de problemas respiratórios e diminuição dos gastos com saúde pública, bem como os benefícios com a diminuição de importação de diesel e possível exportação do biocombustível. 


\subsubsection{Algumas oleaginosas}

Pelo fato de o Brasil ser um país com ampla biodiversidade, pode-se encontrar em território nacional, incontáveis espécies vegetais que podem servir como matérias-primas para a produção de biodiesel.(Suarez, et. al. 2005; Martins, et. al. 2013; Faria, 2010). Dentre as matérias primas disponíveis tem-se destacado oleaginosas como a soja, o algodão, girassol, entre outras.

A soja (Glycinemax (L.) Merrill) é uma das plantas mais antigas cultivadas no mundo e, segundo o Ministério da Agricultura, Pecuária e Abastecimento (MAPA) constitui a cultura brasileira que mais cresceu nas última três décadas, correspondendo a $49 \%$ de toda a área de grãos plantada no país. Tal recurso tem impulsionando inclusive a balança comercial brasileira uma vez que o grão é o principal gerador de divisas cambiais do Brasil, gerando negociações anuais que ultrapassam 20 bilhões de dólares. A produção nacional do óleo extraído da soja por ano é cerca de 5,8 milhões de toneladas, produzidos para fins alimentícios, além de possibilitar sua utilização como biocombustível, que substituindo combustíveis fósseis reduz em até 78\% a emissão de gases poluentes. (Ministério de Minas e Energia, 2015). Quimicamente, o óleo extraído deste grão é constituído por uma mistura de ácidos graxos, são eles: ácido linoleico (Tabela 1, composto (4) (18:2), oleico (18:1), palmítico (16:0), linoleico (18:3) e esteárico (18:0), nas proporções de 56\%, 20\%, 13\%, 7,5\% e $3,2 \%$, respectivamente. (Suppes, 2003)

Segundo o Banco Nacional do Desenvolvimento - BNDS, a produção de mamona vem crescendo no mundo, entretanto, no Brasil foi registrada uma diminuição nos últimos anos, mas mesmo assim, o país ocupa a quarta posição no ranking mundial, produzindo entre 100 e 120 mil toneladas de mamona por ano. A produção do óleo extraído da mamona não apresenta forte potencial na exportação, presume-se que a produção seja suficiente apenas para suprir a demanda nacional. (ANP, 2015). Este óleo é constituído principalmente por ácido ricinoleico (85\%), linoleico (5\%), oleico (3\%), esteárico (1,5\%) e palmítico (1\%). Seu principal constituinte (3) contém uma hidroxila e uma instauração cis na cadeia carbônica. (Suppes, 2003)

O Departamento de Estudos Sócio-Econômicos Rurais (DESER) prevê que o óleo de canola é o terceiro mais consumido no mundo, ficando atrás apenas do óleo de palma e óleo 
de soja, respectivamente. Já no Brasil, o óleo de oliva é o sexto mais consumido para fins alimentícios, não sendo aplicado na indústria (MAPA, 2015). Estes óleos apresentam em comum o principal constituinte, o ácido oleico $(1,2)$, variando apenas a concentração, $75 \%$ e 64,6\%, respectivamente. Em suas composições há ainda os ácidos palmítico, esteárico e linolênico, variando apenas as concentrações.(Suppes, 2003)

\subsubsection{Problematização}

Apesar das inúmeras vantagens oferecidas pelo emprego do biodiesel na matriz energética brasileira e mundial, há registros de problemas relacionados ao seu uso, tais quais as instabilidades oxidativa e microbiana. Tais problemáticas podem levar ao aumento da viscosidade do biodiesel, bem como a diminuição do ponto de fulgor, aumento da acidez, além da corrosão do motor, podendo conduzir o veículo ao entupimento das bombas de injeção e filtros, diminuindo, por sua vez a vida útil do veículo. As imagens contidas na Figura 2 a seguir, disponibilizadas pelo Posto Ipiranga, Petrobrás e Zimmeret. al (2011) mostram o filme formado pelos produtos de oxidação, auto-oxidação e contaminação microbiológica, que são favorecidos pelo contato do biodiesel com o oxigênio atmosférico, migração de partículas de poeira, umidade nos tanques de abastecimento, favorecidos pelo excesso de calor nos recipientes de armazenagem.

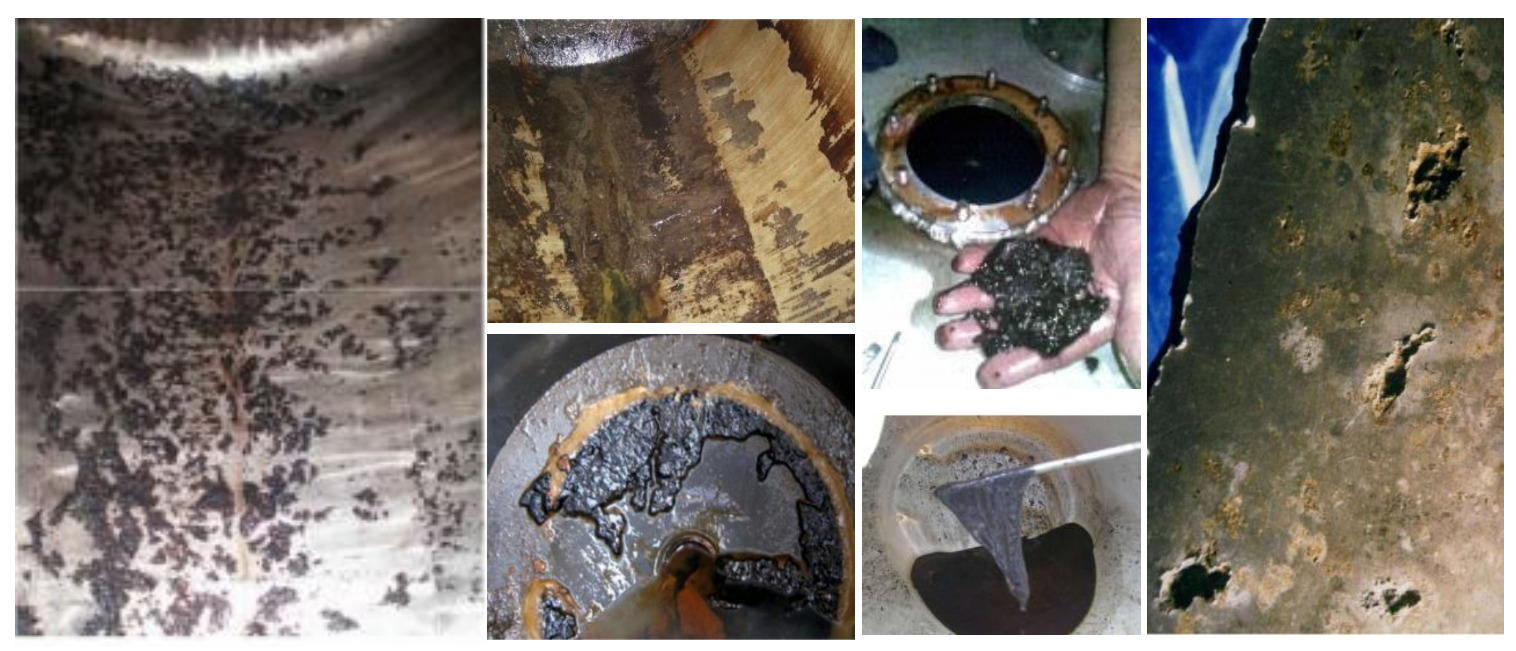

Figura 2: Fotografias de produto formado a partir da oxidação, auto-oxidação e contaminação microbiológica do biodiesel. FONTE: Posto Ipiranga e Petrobrás (2010); Zimmeret. al. 2011 


\subsubsection{Instabilidade Oxidativa}

Apesar das vantagens que oferece, o biodiesel enfrenta uma problemática relacionada à instabilidade oxidativa. Dunn e Knothe relatam que, devido à sua estrutura química apresentar insaturações e o grupo funcional éster, o biodiesel está propenso a ser oxidado e hidrolisado a álcool e ácido carboxílico. Estas reações indesejáveis podem levar a uma diminuição do ponto de fulgor e aumento da acidez, respectivamente, conduzindo o produto a desrespeitar as especificações, tornando-o inutilizado para seu devido fim.

Segundo Maria et. al. os produtos de oxidação aumentam a viscosidade do biocombustível, além de serem corrosivos, o que pode danificar o motor, podendo levar ao entupimento das bombas de injeção e filtros.(Nunes, 2015). Ndana et. al. prevê que a oxidação e auto-oxidaçãosão causadas por três fatores externos, são eles: o contato com o oxigênio do ar, o excesso de calor e, por fim, a formação de compostos hidrolisados devido o contato com umidade em tanques de abastecimento.(Maria, et. al. 2009)

\subsubsection{Suscetibilidade à Contaminação Microbiana}

Além da suscetibilidade do biodiesel à oxidação, há a sensibilidade à contaminação microbiana, comprometendo a qualidade do combustível, diminuindo assim o período de armazenamento e o prazo de validade do mesmo, não sendo recomendado fazer o uso deste quando ultrapassar duas semanas nos postos de abastecimento. Para Bento e Gaylarde, muitos fatores podem contribuir para a contaminação microbiana de biocombustível, tais como a presença de água no fundo dos tanques de armazenamento e a migração de partículas de poeira contaminadas com fungos e bactérias, considerando-se que a matéria orgânica contida nos tanques pode ser alimento para os microorganismos. $\mathrm{O}$ crescimento microbiano pode levar ao bloqueio de gasodutos e filtros, afetando a qualidade do combustível, gerando, portanto, uma preocupação para produtores, fornecedores e consumidores.(Maria, et. al. 2009; Ndana et. al. 2012; Bento, et. al. 2004). 


\subsubsection{Número de Cetano}

O numero de cetano (NC) é uma grandeza relacionada à qualidade da ignição do combustível, de modo que quanto menor for o atraso da ignição, maior será a qualidade do mesmo. (Saldana, et. al. 2011).

O tempo de atraso da ignição (IQT) é medida pela diferença entre o tempo de injeção da amostra e o tempo gasto para a explosão dentro da câmara. A equação 1 remete-se à forma como o equipamento fornece o resultado do teste, de acordo com a norma ASTM D 6890.

$$
D C N=4,460+\frac{186,6}{I D}
$$

Equação 1: Calculo para obtenção do número de cetano, onde, DCN = Número de cetano derivado(Derived Cetane Number) e ID = Demora de ignição (Ignition Delay).

Não constitui necessariamente um problema relacionado ao emprego de biodiesel, entretanto, pode ser otimizada com aditivos químicos. A resolução ${ }^{\circ} 30$ de 23 de junho de 2016 da ANP regulamenta que o limite de NC deve ser igual ou superior a 48 para combustíveis utilizados em motores movidos a diesel S10 (ANP, 2016).

\subsection{Utilização De Nitrocompostos Graxos Em Biodiesel}

Os principais produtos obtidos a partir da reação de nitração são empregados como propelentes e explosivos. Há ainda relatos da utilização destes compostos como aditivos para biocombustível, que no geral são empregados para melhorar a queima do mesmo (Von Holleben, et. al. 1996).

A capacidade de nitroderivados em aperfeiçoar a combustão é conhecida desde 1846, quando Ascanio Sobrero obteve pela primeira vez a trinitroglicerina, explosivo amplamente 
utilizado até os dias atuais. No ano seguinte, o mesmo pesquisador anunciou ainda a descoberta de mais dois explosivos à base de nitroderivados, são eles, nitromanita e nitrolactase. (Valença, 2001)

Há relatos do emprego de nitroderivados de origem petroquímica, como o octilo nitrato. Entretanto, o 2-etil-hexil-nitrato (EHN) domina o mercado de melhoradores de cetano. Ambos utilizados como aditivos ao óleo diesel convencional. Tal mistura pode aumentar o numero de cetano em até cinco pontos. (Canoira et al. 2007).

A combinação de uma estrutura contendo uma cadeia longa e um grupamento nitro satisfaz as propriedades fundamentais de um potencial melhorador de cetano. Além disso, há relatos da utilização de compostos anfifílicos (uma face polar e outra apolar contemplados em uma única molécula) aumenta a lubricidade, gerando assim uma dupla funcionalidade, tornando assim, compostos com essas características muito interessantes, do ponto de vista econômico e ambiental. (Suppes e Mohanprasad, 2003).

Não há por sua vez registros na literatura envolvendo o emprego de nitratos graxos visando à utilização como aditivos para combustível ou biocombustível, aproveitados como inibidor de contaminação microbiana ou melhoradores da estabilidade oxidativa. 
PARTE EXPERIMENTAL 


\section{PARTE EXPERIMENTAL}

Considerando-se a importância da modificação molecular de óleos vegetais para fins de produção de aditivos para biocombustível, algumas reações tornaram-se comuns em grupos de pesquisa de todo o mundo. Já que, fica claro que as resoluções destes problemas não se contentam em ficar, apenas no domínio ambiental, mas extrapola-se para o âmbito social, agrário, industrial e econômico, já que capacitaria o Brasil para a exportação (Masiero, et. al. 2008).

Neste sentido, conforme destacado anteriormente, o presente trabalho propõe a síntese e a caracterização de compostos planejados a partir de óleos vegetais, que apresentem similaridade física e química com o biodiesel. Que apresentem ainda multifuncionalidade, revelando, possivelmente atividades antioxidantes, biocidas e melhoradoras de cetano e poder calorífico, tudo contemplado em uma mesma substância, permitindo um aumento do tempo de estocagem com garantia de manutenção da qualidade do biocombustível, que também deve aumentar a vida útil do veículo.

A proposta inclui a síntese de nitratos orgânicos, conforme esquematizados na Tabela 1, juntamente com seus respectivos intermediários, onde todos os compostos foram planejados a partir de óleo oriundo de biomassa, gerando assim uma fonte de energia renovável. A rota sintética empregada para a obtenção dos aditivos nitrados abrangem etapas e reagentes de baixo custo, e, além disso, a aditivação deve ser realizada em quantidades vestigiais.

A primeira etapa do planejamento sintético consiste na preparação do biodiesel, partindo de quatro óleos vegetais, são eles: óleo de oliva (1), canola (2), mamona (3) e soja (4). Os álcoois escolhidos como substratos da transesterificação foram: metanol $\left(\mathrm{CH}_{3} \mathrm{OH}\right)$, etilenoglicol $\left(\mathrm{C}_{2} \mathrm{H}_{6} \mathrm{O}_{2}\right)$ e glicerina $\left(\mathrm{C}_{3} \mathrm{H}_{8} \mathrm{O}_{3}\right)$, fornecendo os produtos enumerados de (5) à (16), a metodologia empregada nesse processo foi descrita por Schuchardt e colaboradores.

A segunda etapa foi descrita por Suppes e colaboradores a fim de obter os epóxidos $(17,18,19,20)$. A terceira etapa consiste na solvólise ácida de uma alíquota dos respectivos epóxidos, funcionalizados com uma hidroxila alcoólica e uma metoxila $(21,22,23,24)$. A quarta etapa consiste o rompimento do anel oxiurânico, levando à formação de produtos poli- 
hidroxilados. A última etapa sintética, também descrita Suppes et. al. leva à formação dos derivados alvo (29) à (45), onde a reação de nitração ocorre na presença de ácido nítrico. 


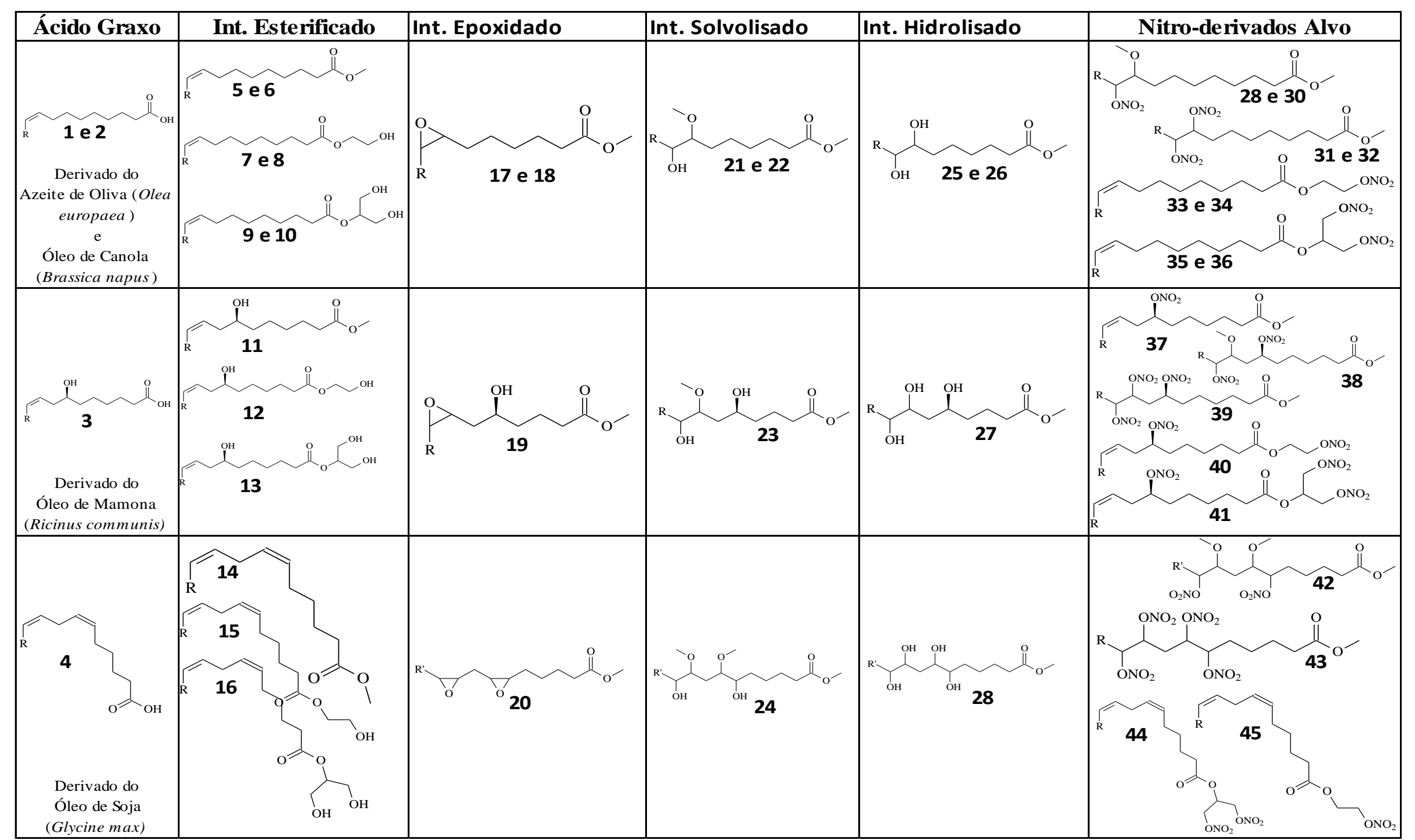

Tabela 1: Produtos e intermediários esperados. Onde $\mathrm{R}$ corresponde ao restante de átomos de carbono para completar uma cadeia com 18 carbonos, contando a partir da carbonila. FONTE: Próprio autor. 


\subsection{METODOLOGIAS SINTÉTICAS}

\subsubsection{Transesterificação do óleo vegetal, para a obtenção do biodiesel.}

\subsubsection{Transesterificação do óleo vegetal, para a obtenção do biodiesel metílico.}

A transesterificação ocorre entre um triacilglicerídeo e um álcool de cadeia curta, na presença de um catalisador ácido ou básico, resultando na formação de monoésteres oriundos de ácidos graxos. (Suarez, et. al. 2007).

Nesta reação há a formação do íon metóxido $\left(\mathrm{CCCH}_{3}\right)$, que é o catalisador ativo. No caso da catálise básica o íon é formado através da abstração do hidrogênio ácido do álcool pelo catalisador. Esta unidade química atua como nucleófilo, atacando assim as moléculas de triacilglicerídeos, resultando na formação de ésteres metílicos, como esquematizado no Esquema 1 a seguir. (Suarez, et. al. 2004).

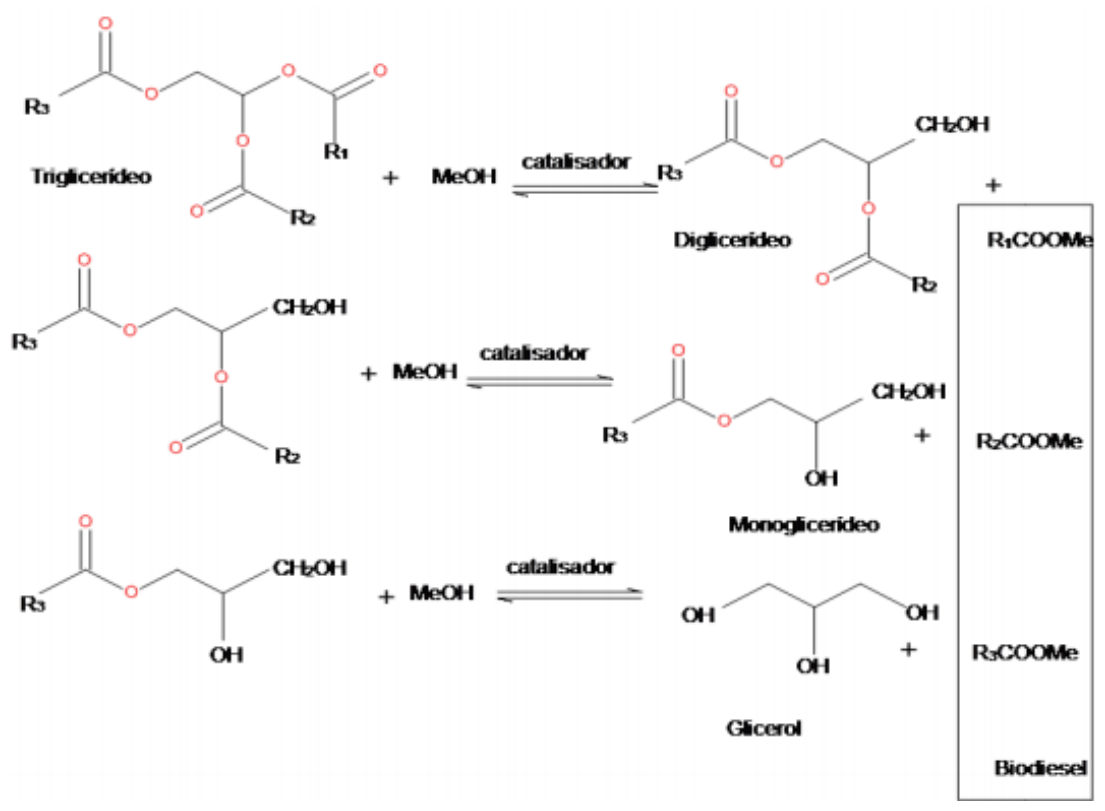

Esquema 1: Transesterificação de triacilglicerídeos. (Oliveira, 2013). 
O Esquema 2, representado a seguir, representa, de maneira geral, a reação de transesterificação, cujas metodologias estão descritas nos próximos dois tópicos.

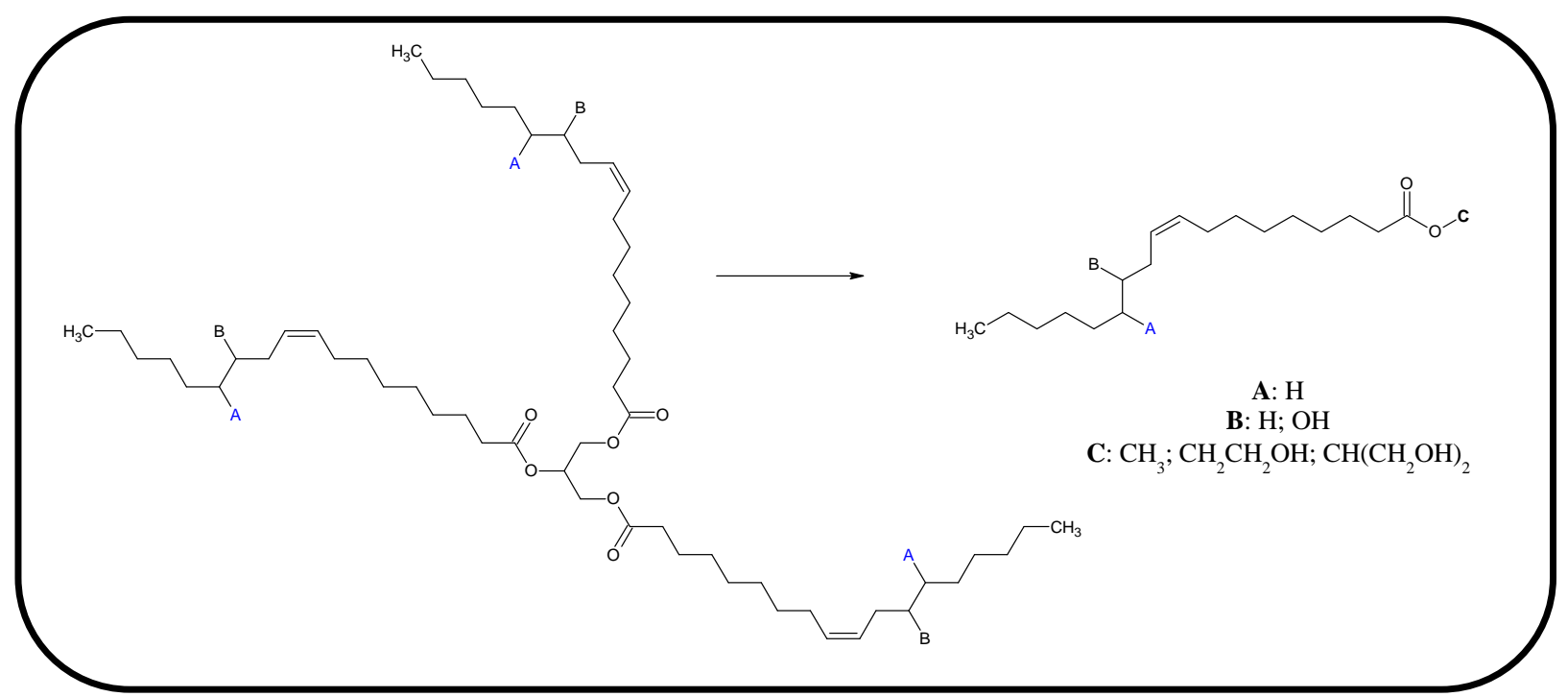

Esquema 2:Reação genérica de esterificação. FONTE: Prórpio autor

O biodiesel metílico foi obtido por intermédio da reação de transesterificação, fazendo-se o uso de hidróxido de potássio como catalisador básico, que foi dissolvido em metanol na proporção de massa/massa 1:40, respectivamente. O concernente ácido graxo foi previamente seco em um balão do tipo Schlenk por cerca de $20 \mathrm{~min}$. Em seguida, o produto da dissolução do catalisador foi adicionado ao óleo. A mistura reacional foi então submetida à agitação magnética por $2 \mathrm{~h}$ sob banho à $60^{\circ} \mathrm{C}$.

Ao final da reação foi possível observar a formação de duas fases, a superior contendo o produto desejado, e a inferior contendo principalmente glicerina e o excesso de metanol. A segunda fase foi descartada, com o auxílio de um funil de decantação e a primeira lavada, no mesmo recipiente, com água destilada em abundancia. A fim de economizar água neste processo, fez-se o uso de solução de ácido fosfórico na concentração de $10 \%$ volume/volume. O material bruto obtido foi filtrado em funil de placa sinterizada contendo terra de infusórios, e novamente seco à pressão reduzida com auxílio de bomba.

Realizou-se, em seguida uma análise no equipamento de HPLC, a fim de verificar a taxa de conversão da reação. A depender do resultado obtido, a síntese deve ser refeita até se obter no 
mínimo 96,5\% de biodiesel, conforme norma estabelecida pela ANP (Resolução 45 de 25/08/2014). Esta etapa sintética foi realizada quatro vezes, partindo de óleos diferentes, são eles: óleo de soja, canola, oliva e mamona, que justifica a variação na estrutura química, representado pelas letras A, B e C no esquema acima. Por fim, o material obtido, líquido amarelo foi armazenado em freezer, de modo a evitar degradação e oxidação do mesmo.

\subsubsection{Transesterificação do óleo vegetal, para a obtenção do biodiesel derivado do etilenoglicol e glicerina.}

Em um reator do tipo PARR adicionou-se o óleo vegetal previamente seco e o catalisador óxido de dibutilestanho IV na proporção massa/massa de 100:1. Para obter-se um éster com substituinte derivado do etilenoglicol, adicionava-se este álcool com o excesso de 3 equivalentes em quantidade de matéria. Já, para a obtenção de um éster derivado na glicerina, o excesso foi de 2 equivalentes em mol. Esta reação foi realizada oito vezes, partindo dos quatro óleos e os dois álcoois. O material esbranquiçado obtido foi armazenado em freezer, a fim de evitar degradação ou oxidação do mesmo.

\subsubsection{Nitração do biodiesel derivado do etilenoglicol e glicerina, para obtenção dos primeiros nitro-derivados.}

A nitração é uma das reações de substituição diretas mais utilizadas devido à facilidade de separação dos produtos e aplicações dos mesmos. Tal reação consiste na introdução irreversível de um ou mais grupos nitro $\left(-\mathrm{NO}_{2}\right)$ em uma molécula orgânica. A execução desta reação exige uma demanda energética muito baixa, necessitando, portanto de baixas temperaturas, que também garante segurança em sua efetivação. A formação de nitratos orgânicos pode portanto, ser obtida através da reação direta entre álcoois alifáticos e um agente de nitração, conforme demonstrado a seguir (Poirieret. al. 1995)

$$
\mathrm{R}-\mathrm{OH}+{ }^{+} \mathrm{NO}_{3} \longrightarrow \mathrm{R}-\mathrm{O}-\mathrm{NO}_{2}+\mathrm{H}_{2} \mathrm{O}
$$


O ácido nítrico puro pode ser utilizado sozinho como agente nitrante, entretanto, deste modo trata-se de um agente fraco para muitas aplicações. Assim, a utilização de um co-ácido é uma alternativa viável, já que este agente químico tem um importante papel. O co-ácido facilita a ionização do agente nitrante, facilitando assim a produção de $\mathrm{NO}_{2}{ }^{+}$. A mistura arrefecida dos ácidos é conhecida na literatura por "ácido misto", tal mistura apresenta os benefícios de baixo custo e alto potencial nitrante. A reação 2 sugere a utilização do ácido sulfúrico como co-ácido. (Olah et. al. 1989).

$$
\mathrm{HNO}_{3}+\mathrm{H}_{2} \mathrm{SO}_{4} \rightleftharpoons \mathrm{NO}_{2}^{+}+\mathrm{HSO}_{4}^{-}+\mathrm{H}_{3} \mathrm{O}^{+}
$$

Há relatos na literatura da utilização de diversos ácidos como co-ácido, como o fosfórico, fluorídrico, cloridrico e ácético, entretanto todos apresentam limitações. Assim, o anidrido acético misturado com ácido nítrico fornece o nitrato de acetilo que vem mostrando ser um potente agente nitrante, menos propenso a promover hidrólise ou oxidação do substrato ou produto. Os equilíbrios representados abaixo representam os equilíbrios decritos. (Suppes e Mohanprasad, 2003)

$$
\begin{array}{r}
\mathrm{HNO}_{3}+\left(\mathrm{CH}_{3} \mathrm{CO}\right)_{2} \mathrm{O} \rightleftharpoons \mathrm{CH}_{3} \mathrm{COONO}_{2}+\mathrm{CH}_{3} \mathrm{COOH} \\
\mathrm{CH}_{3} \mathrm{COONO}_{2}+\mathrm{HNO}_{3} \rightleftharpoons \mathrm{CH}_{3} \mathrm{COOH}+\mathrm{N}_{2} \mathrm{O}_{5} \\
\mathrm{~N}_{2} \mathrm{O}_{5}+\left(\mathrm{CH}_{3} \mathrm{CO}\right)_{2} \mathrm{O} \rightleftharpoons \mathrm{CH}_{3} \mathrm{COONO}_{2}
\end{array}
$$

O Esquema 3, representa, de maneira geral, a reação de nitração, cuja metodologia encontra-se descrita a seguir. 


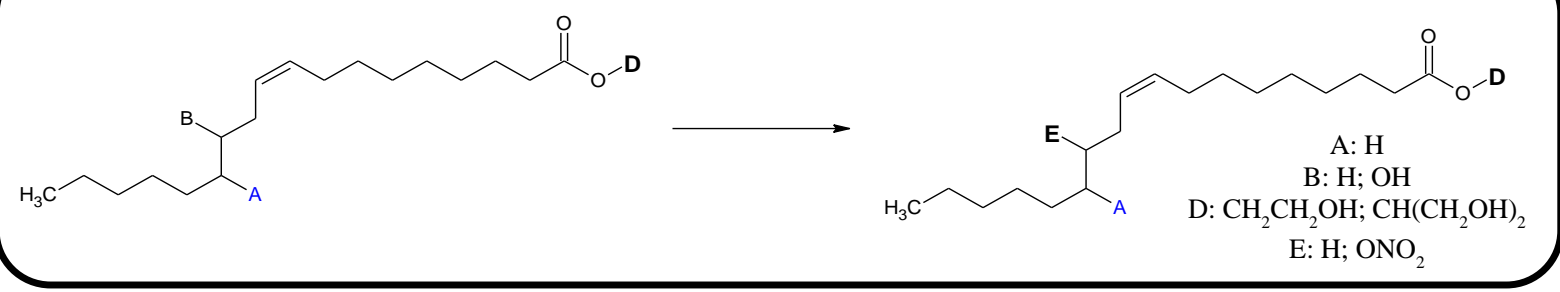

Esquema 3: Reação genérica de otenção dos primeiros nitro-derivados alvo. FONTE: Próprio autor.

A fim de obter-se derivados conforme representados acima, adicionou-se em um erlenmeyer o biodiesel e diclorometano para tornar o substrato menos viscoso e reservou-se a mistura. Em um béquer submerso em um banho de gelo a $5{ }^{\circ} \mathrm{C}$ adicionou-se lentamente ácido nítrico (2,5 equivalentes em quantidade de matéria, para cada hidrogênio ácido que será substituído, em relação ao biodiesel) ao anidrido acético (2,9 equivalentes, para cada hidrogênio ácido que será substituído). Esta etapa da reação foi realizada com muito cuidado, já que é bastante perigosa, considerando-se o risco de explosão, bem como a liberação de gás $\mathrm{NO}_{2}$ que é altamente tóxico ao ser humano.

Ao erlenmeyer contendo o biodiesel dissolvido adicionou-se a mistura de ácidos, fechou-se o sistema com um septo e submeteu-se a mistura à reação sob agitação magnética vigorosa por $2 \mathrm{~h}$ em um banho de gelo a $10{ }^{\circ} \mathrm{C}$. O produto bruto, obtido ao final foi transferido para um funil de decantação onde foi lavado abundantemente com solução supersaturada de bicarbonato de sódio visando neutralizar o excesso de ácido presente no sistema. Cada produto castanho obtido foi seco à pressão reduzida de modo a garantir que não haja água no composto.

Os primeiros compostos alvos alcançados foram então submetidos a alguns testes químicos, físico-químicos e biológicos.

\subsubsection{Epoxidação de biodiesel}

A reação de epoxidação é uma das mais comuns na modificação de produtos naturais, inclusive de bioóleos e biodiesel, tendo em vista que o pequeno anel que constitui este grupo funcional apresenta uma considerável reatividade química, tornando-se suscetível a reações com diversos nucleófilos e eletrófilos. Justificada pela grande tensão angular do anel de três membros, 
fornecendo produtos com até dois carbonos quirais.A reação é produzida a partir da adição de um perácido orgânico com óleo vegetal insaturado. Uma reação genérica está representada no Esquema 4 a seguir (Ouad, et.al. 2001 e Pedrozo et. al. 2009)
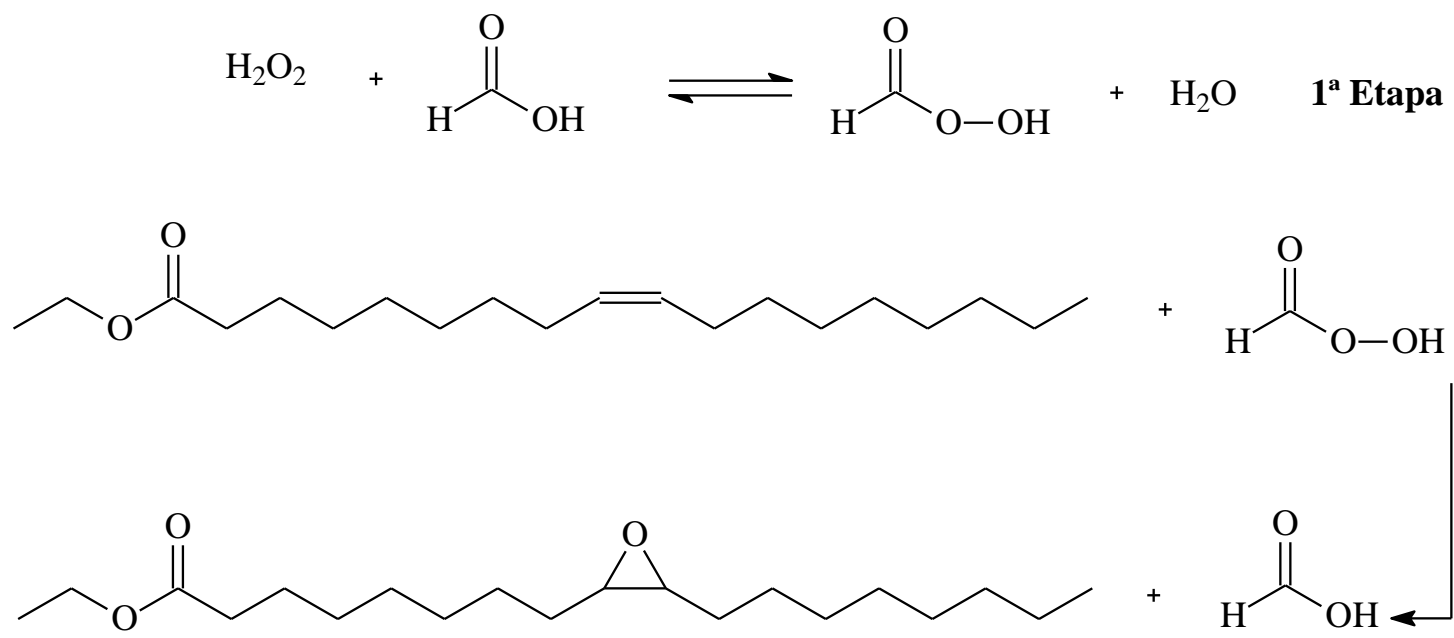

$2^{\text {a }}$ Etapa

Esquema 4: Representação genérica da reação de epoxidação. FONTE: (Pedrozo, et. al. 2009- adaptado)

O Esquema 5, representa, de maneira geral, a reação de epoxidação cuja metodologia encontra-se descrita a seguir.

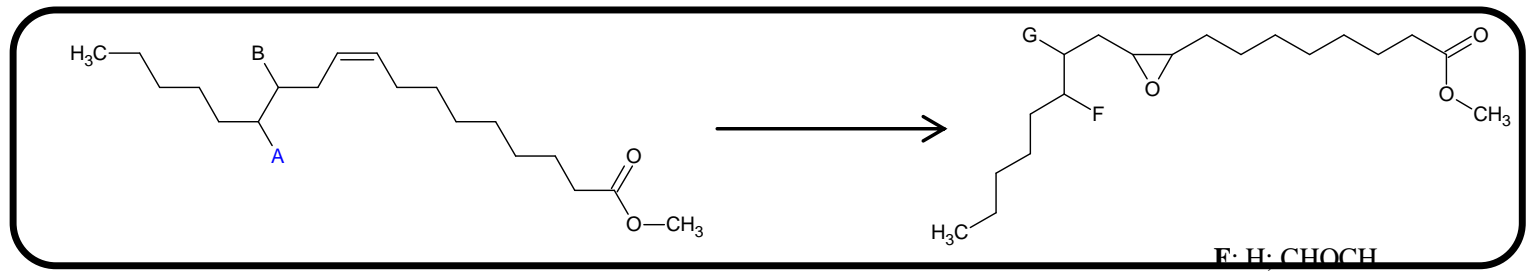

Esquema 5: Reação genérica de obtenção dos epóxidos de éster metílico. FONTE: Próprio autor.

A reação de epoxidação foi realizada partindo-se apenas dos ésteres metoxilados, derivados dos ácidos graxos, obtidos conforme a metodologia descrita anteriormente. Os demais ésteres não foram submetidos a esta reação devido a grande dificuldade em tratá-los.

Cada biodiesel foi colocado em um balão de fundo redondo e a este, adicionou-se ácido fórmico e peróxido de hidrogênio. A proporção molar seguida foi de 1:1:4 respectivamente. A mistura reacional foi então submetida à agitação magnética vigorosa a $45^{\circ} \mathrm{C}$ por $6 \mathrm{~h}$. Findado este 
período foi possível observar a formação de duas fases, a orgânica contendo o biodiesel epoxidado e a aquosa contendo o excesso de ácido carboxílico, peróxido de hidrogênio e água. Objetivandose a neutralização destes compostos, transferiu-se o conteúdo do balão para um funil de decantação, descartou-se a fase aquosa e lavou-se o produto epoxidado com abundancia de solução supersaturada de bicarbonato de sódio $\left(\mathrm{NaHCO}_{3}\right)$. Ao fim do processo, o material obtido, liquido, esbranquiçado, foi seco à pressão reduzida e armazenado em freezer a baixas temperaturas.

\subsubsection{Abertura do anel epóxido}

É sabido que, em meio ácido, o oxigênio do epóxido é protonado, fornecendo assim um íon de carga positiva, suscetível ao ataque de nucleófilos como a água e o metanol, através da interação dipolo permanente- íon. Geralmente, em casos de epóxidos assimétricos a quebra do anel oxiurânico ocorre preferencialmente por meio de um ataque ao carbono mais substituído, devido a uma maior estabilização da carga sobre o carbono. Uma reação genérica está representada a seguir (Biggs, et. al. 1971).

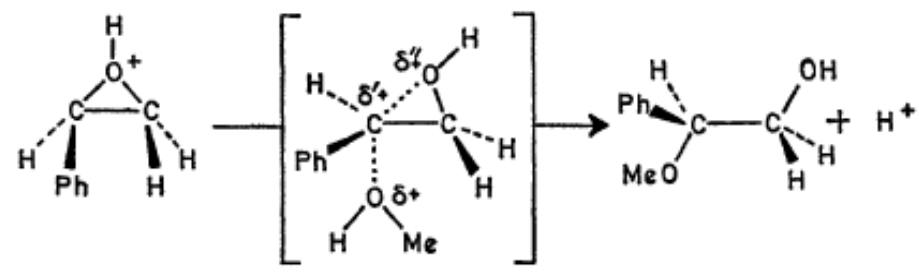

Esquema 6: Representação genérica da reação de hidrólise e solvólise. FONTE: (Biggs,1971)

\subsubsection{Abertura do epóxido: Hidrólise.}

O Esquema 7, representa, de maneira geral, a reação de abertura do anel oxiurânico, visando a obtenção de produtos di ou poli-hidroxilado, cuja metodologia encontra-se descrita a seguir. 


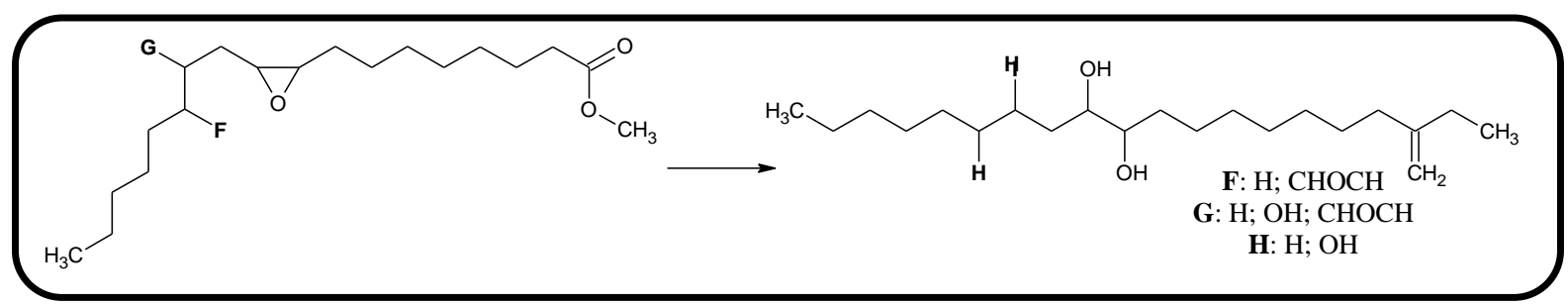

Esquema 7: Reação genérica de obtenção dos compostos hidroxilados. FONTE: Próprio autor.

A primeira reação de abertura do epóxido foi preparada em um balão de fundo redondo, onde adicionou-se a metade de todo o conteúdo do composto epoxidado, separando-se a outra metade para a etapa subsequente. Adicionou-se em seguida um excesso significativo de água destilada (para cada $1 \mathrm{~g}$ de epóxido, adicionou-se $2 \mathrm{~mL}$ do solvente), por ultimo, adicionou-se em quantidade catalítica o ácido $p$-toluenossulfônico ${ }^{1}$ (2,5\% em relação à quantidade de matéria de epóxido). A mistura reacional foi submetida à agitação vigorosa por $24 \mathrm{~h}$ à temperatura ambiente. Ao fim, observou-se a formação de duas fases, colocou-se então o material bruto em um funil de decantação para descartar o excesso de água e lavou-se, a fim de retirar um possível excesso de catalisador. Posteriormente, o resíduo de água que possa ter ficado no produto foi retirado à pressão reduzida. O produto amarelado foi armazenado em freezer até a realização da próxima etapa sintética.

\subsubsection{Abertura do epóxido: Solvólise}

A reação de solvólise do biodiesel epoxidado descrita no Esquema 8 deu-se pela metodologia semelhantemente à da etapa anterior, variando-se apenas o solvente, enquanto na hidrólise usou-se água, na solvólise utilizou-se metanol nas mesmas proporções. Ao fim, o material bruto obtido foi colocado em evaporador rotativo a fim de retirar o excesso de metanol à

\footnotetext{
${ }^{1} \mathrm{Na}$ maioria das vezes, o referido catalisador necessitou de tratamento prévio, já que por intermédio da coloração (rósea) do mesmo foi possível observar nitidamente a presença de impurezas. Este tratamento deu-se através da rápida filtração do composto com acetato de etila gelado. A filtração foi realizada em funil de Büchner usando-se papel de filtro e o auxílio de uma bomba a vácuo.
} 
pressão reduzida, antes da lavagem para retirada do possível excesso de catalisador. O produto amarelado foi armazenado em freezer até a realização da próxima etapa sintética

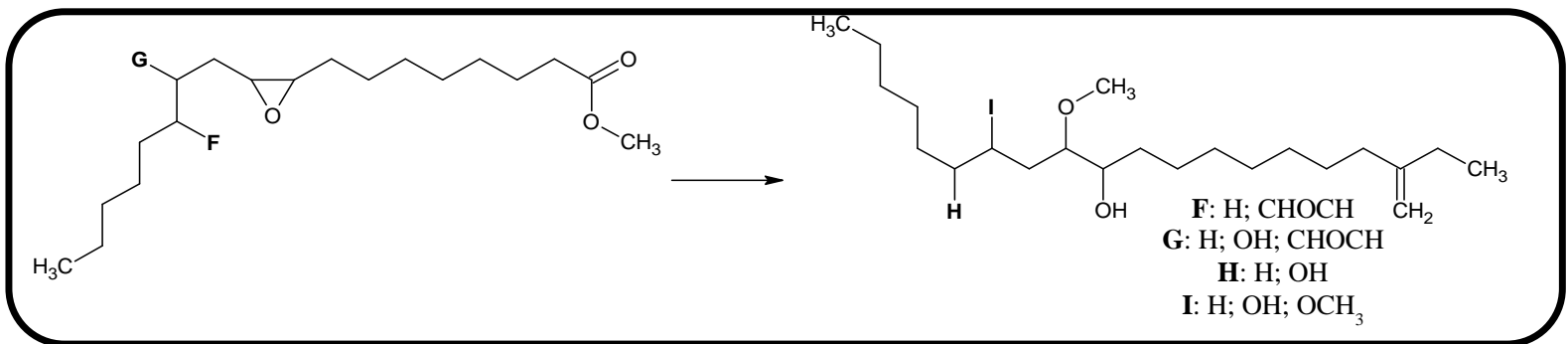

Esquema 8: Reação genérica de obtenção dos compostos metoxilados. FONTE: Próprio autor.

\subsubsection{Nitração dos produtos hidroxilados e metoxilados.}

As reações de nitração ilustradas no Esquema 9 foram realizadas partindo-se da mesma metodologia descrita no item 5.1.2 diferindo-se apenas os substratos de partida, que hora fora o produto de hidrólise, hora o produto de solvólise. Fornecendo, assim os segundos e terceiros lotes de produtos nitrados.

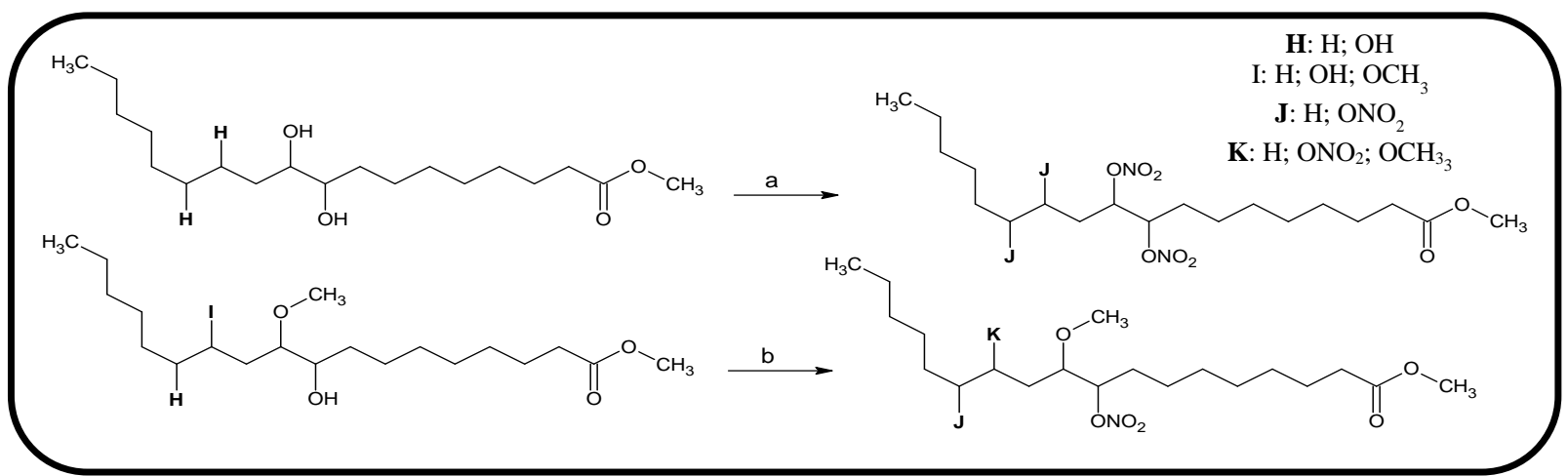

Esquema 9: Reações genéricas para a obtenção dos nitratos advindos de produtos hidroxilados ou metoxilados. FONTE: Próprio autor.

\subsection{Metodologia Dos Testes Biológicos}

Após a caracterização, os produtos foram submetidos a testes biológicos frente a fungos e bactérias, a fim de testar o potencial biocida ou bioestáticos. Os microorganismos testados foram os fungos A. nigere A. funigattue as bactérias Bacillussubtillise Acinetobacter sp. Tais escolhas 
foram realizadas devido a presença, em abundância destes microorganismos no ar, além de serem dos principais contaminantes de biodiesel.

\subsubsection{Preparação do meio de superfície com ágar}

O meio de inoculação do microorganismo foi preparado a partir da adição do Ágar Sabouraud e Ágar Nutriente, seguido da adição de excesso de água destilada. A mistura foi submetida a aquecimento até dissolução completa. Após, a mesma foi colocada na autoclave por cerca de $1 \mathrm{~h}$, de modo a garantir que não haja contaminação biológica neste meio. Após esterilização foram adicionados cerca de $20 \mathrm{~mL}$ do meio nas placas de Petri previamente esterilizadas. O processo de transferência do meio para as placas foi realizado em ambiente esterilizado com lâmpada ultravioleta e etanol $96 \%$, as quais foram armazenadas em geladeira por 36 h.

\subsubsection{Preparação do meio de cultura}

O meio de cultura de fungos filamentosos foi preparado a partir do micélio derivados de culturas cultivadas em bata dextrose por 5 dias a $35^{\circ} \mathrm{C}$. A suspensão foi preparada com os esporos dos fungos filamentosos e solução salina previamente esterilizada $(0,85 \%)$. A densidade celular fora medida em espectrofotômetro para uma transmitância de $85 \%$ em comprimento de onda de $530 \mathrm{~nm}$.

O inóculo bacteriano foi preparado a partir de colônias de bactérias cultivadas em caldo nutritivo por $24 \mathrm{~h}$ a $35^{\circ} \mathrm{C}$. Em seguida, selecionou-se colônias isoladas, transferindo-as para um tubo contendo solução salina com concentração de $0,85 \%$. A suspensão bacteriana obtida foi então comparada com o padrão 0,5 da escala McFarland.

\subsubsection{Preparação das placas de ensaio}


O inóculo microbiano contendo as referidas bactérias e fungos foi individualmente aplicado nas placascontendo o meio de superfície, pela técnica de espalhamento em superfície com o auxílio de swabs estéreis. O inoculo foi semeado sobre toda a superfície do ágar, de modo a se obter um crescimento uniforme. A técnica consiste na formação de um orifício com aproximadamente $6 \mathrm{~mm}$ de diâmetro realizada no meio de superfície após a incubação. Há a possibilidade de realizar vários destes orifícios em uma única placa, a depender do tamanho da mesma e do halo de inibição do composto a ser testado, caso haja. Durante a incubação, as substâncias difundem-se dos orifícios para o meio de cultura. As cepas bacterianas e fúngicas utilizadas foram padronizadas segundo a ATCC (American TypeCultureCollection).

O controle negativo foi realizado através da adição diesel S-10 em um dos orifícios realizados no meio de cultura. Seguido da adição dos compostos a ser testados em outros buracos devidamente identificados e localizados estrategicamente na placa de ensaio. Os testes foram realizados em triplicata para cada microorganismo testado. As placas prontas foram então armazenadas em um recipiente à temperatura ambiente por uma semana. Após este período de incubação os resultados foram notificados, considerando-se com atividade aqueles produtos que inibiram o crescimento microbiano, produzindo uma média de halos de inibição iguais ou superiores a $10 \mathrm{~mm}$. Os halos de inibição foram medidos, incluindo-se o diâmetro da perfuração, com o auxílio de projetor ótico, régua milimetrada ou paquímetro.

\subsection{Caracterização dos Produtos e Intermediários}

A avaliação dos grupos funcionais dos compostos foi feita por espectroscopia na região do infravermelho (IV), obtidos através de um espectrômetro FT-IR, modelo IR Prestige da Shimadzu, usando a célula de ATR, modelo ATR Miracle, abrangendo a região de 650 a $4000 \mathrm{~cm}^{-1}$.

Os produtos de síntese foram caracterizados em espectro de Ressonância Magnética Nuclear $(\mathrm{RMN})$ de hidrogênio $\left({ }^{1} \mathrm{H}\right)$ e carbono $\left({ }^{13} \mathrm{C}\right)$, obtidos em equipamento VarianGemini 300 MHz e $600 \mathrm{MHz}$, cujos deslocamentos químicos foram obtidos em partes por milhão (ppm) e referenciados pelo sinal do TMS. A multiplicidade dos sinais expressos nos espectros de RMN de ${ }^{1} \mathrm{H}$ foi indicada com a nomenclatura a seguir: s (simpleto), $\mathrm{d}$ (dupleto), $\mathrm{t}$ (tripleto), dd (duplo dupleto), q (quarteto), qt (quinteto) e m (multipleto). 


\subsection{Estabilidade Oxidativa}

A estabilidade oxidativa foi realizada seguindo a norma EN14112, por intermédio do equipamento 873 Biodiesel Rancimat da Metrohm Pensalab. A análise foi obtida pela medida do tempo gasto para que $3 \mathrm{~g}$ de amostra fossem oxidadas, expondo-a a uma temperatura de $110^{\circ} \mathrm{C}$ e fluxo de ar de $10 \mathrm{~L} / \mathrm{h}$. Tal método é descrito nas especificações da ANP para teses de oxidação acelerada.

\subsection{Viscosidade e Densidade}

A viscosidade e densidade foram obtidas através de equipamento digital Stabinger Viscometer, da Anton Paar, modelo SVM 3000. As análises foram realizadas através da injeção da amostra em local apropriado do equipamento, onde foram obtidas a viscosidade e densidade em 20 e em $40{ }^{\circ} \mathrm{C}$. Entretanto, o resultado considerado para os devidos fins foi apenas os obtidos a 40 ${ }^{\circ} \mathrm{C}$ por uma questão de especificação da ANP (Resolução no 45 de 25 de agosto de 2014).

\subsection{Número De Cetano Derivado}

Os valores de numero de cetano derivado foram obtidos por intermédio de um equipamento do tipo IgnitionQualityTester LM (AdvancedEngineTecnhnologu LTDA). Tal técnica fora determinada segundo a norma ASTM d 6890.

Para a realização dos testes foi necessária a filtração prévia da amostra, tal procedimento é necessário para garantir que não haja partículas que venham a entupir o bico injetor do equipamento. Tal equipamento provoca a completa combustão da blenda de combustível sob condições de pressão e temperatura controladas.O resultado do teste é então obtido pela média de 32 varreduras. 
RESULTADOS E DISCUSSSÃO 


\section{RESULTADOS E DISCUSSÃO}

\subsection{Aspectos Visuais Gerais}

A ocorrência da reação de transesterificação pôde ser observada por intermédio da perceptível diminuição da viscosidade do produto em relação ao reagente. A reação de epoxidação é visualmente constatada pela mudança da coloração, que passa de amarelo para branco. Já nas reações de hidrólise e solvólise não é possível identificar, de maneira visual o acontecimento reacional. De toda a rota sintética proposta neste trabalho a nitração é a mais facilmente percebida visualmente, de modo que ocorre uma mudança na coloração, passando de amarelada para castanho, variando-se o tom destes compostos, onde, de modo geral, quanto mais grupamento nitro na estrutura, mais escuro o produto final.

\subsection{Caracterização De Biodiesel}

\subsubsection{Cromatografia Líquida de Alto Desempenho (HPLC)}

Os oleatos de metila foram obtidos em boas taxas de conversão como pode ser observado na Tabela 2. Para obterem-se tais resultados, foram realizadas análises em aparelho de Cromatografia Líquida de Alto Desempenho (HPLC), onde um cromatograma foi plotado seguindo o exemplo do biodiesel de soja que está representado na Figura 6. Na Figura 3 tem-se o cromatograma do óleo de soja (material de partida da reação). Os dados de conversão foram obtidos através da determinação dos teores de cada componente do óleo que não tenham sido convertidos em biodiesel. Onde a presença dos triacilglicerídeos (TAG) é caracterizada pelo aparecimento de picos após 12,50 min, o diacilglicerídeo (DAG) é caracterizado por picos entre 7,80 e 12,50 min, o monoacilglicerídeo (MAG) e o ácido graxo (AG) apresentam sinais em até 5,79 min, por fim, o biodiesel é caracterizado pelos picos em 5,79 e 7,80 min. A Figura 4, representa um exemplo desta conversão, para biodiesel de soja. 


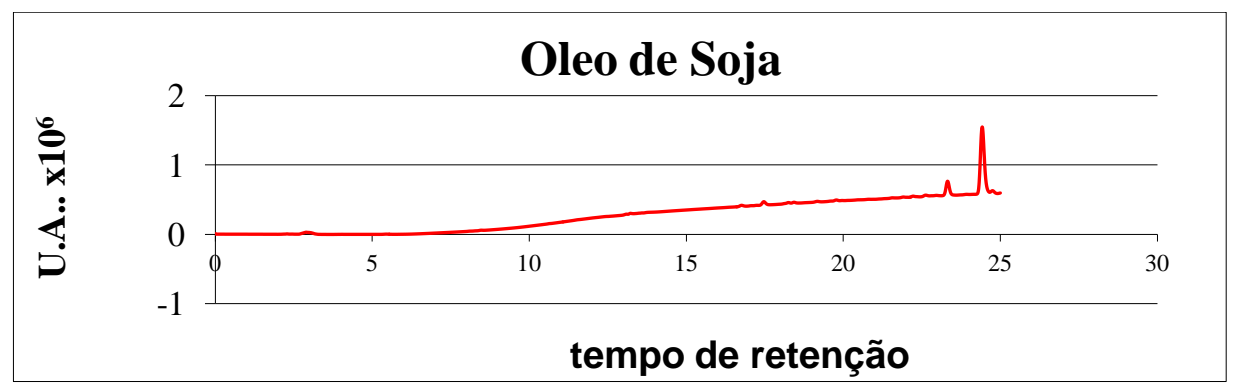

Figura 4: Cromatograma do óleo de soja, obtido em HPLC. FONTE: Próprio autor.

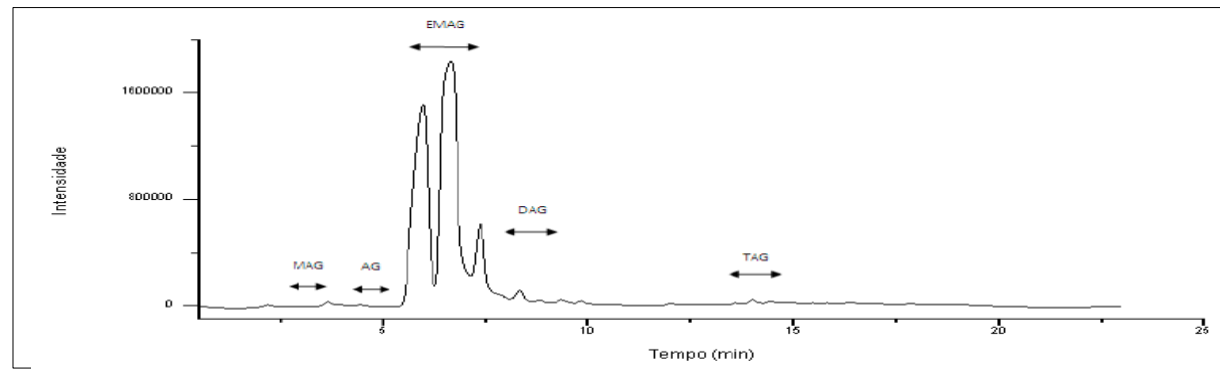

Figura 5: Cromatograma do biodiesel de soja, obtido em HPLC. FONTE: Próprio autor.

\begin{tabular}{l|l}
\hline Biodiesel & Rendimento \% \\
\hline 5 & 82 \\
\hline 6 & 100 \\
\hline 11 & 49,29 \\
\hline 14 & 99,93 \\
\hline
\end{tabular}

Tabela 2: Taxa de conversão do biodiesel metílico de oliva, canola, mamona e soja, respectivamente. FONTE: Próprio autor.

\subsubsection{Espectroscopia na região do Infra-vermelho (IV)}

Os compostos alvo e intermediários foram caracterizados por espectroscopia na região do infravermelho (IV). Para fins comparativos, os espectros de IV foram organizados de modo sobrepostos nos anexos de 1 a 8, onde os ímpares correspondem aos ácidos graxos, seguido dos ésteres derivados do etilenoglicol e da glicerina, além dos nitratos advindos destes mesmos 
ésteres, respectivamente. Os anexos pares referem-se aos respectivos ésteres metílicos, seguidos dos epóxidos, solvolisados, hidroxilados e seus respectivos nitratos.

Em todos os espectros de IV observa-se as vibrações características da carboxila de éster reveladas pela banda de absorção em torno de $1743 \mathrm{~cm}^{-1}$. A banda de intensidade média em aproximadamente $1183 \mathrm{~cm}^{-1}$ refere-se às vibrações correspondentes ao estiramento da ligação C-O do éster. As bandas de absorção em $3015 \mathrm{~cm}^{-1}$ satisfazem à(s) ligação(ões) de grupo(s) olefínico(s) que em $723 \mathrm{~cm}^{-1}$ é caracterizado como insaturação cis. No caso dos ácidos graxos (1, 2, 3 e 4) a banda referente a ligações $\mathrm{O}-\mathrm{H}$ de ácido aparecem sobrepostas às absorções referentes às ligações C-H, em $2920 \mathrm{~cm}^{-1}$, impossibilitando assim sua identificação, que é caracterizada pela presença de outras ligações.

A formação do éster metílico $(5,6,11$ e 14) não pode ser afirmada com propriedade partindo-se apenas dos espectros de IV, já que com a reação de transesterificação o grupo funcional não foi alterado nem a(s) olefina(s) sofreram modificação, havendo assim a necessidade dos espectros de RMN para a caracterização destes compostos, que serão discutidos posteriormente.

Os produtos de esterificação obtidos pelo uso de etilenoglicol (7, 8, 12 e 15) e glicerina (9, 10, 13 e 16) como substratos não tiveram a taxa de conversão estimada pelo intermédio do cromatograma gerado pelo HPLC. A conversão do biodiesel derivado do etilenoglicol e da glicerina foi caracterizada emitindo sinal de absorção referente ao estiramento da ligação $\mathrm{OH}$ de álcool primário em aproximadamente $3380 \mathrm{~cm}^{-1}$, evidenciando, assim, a formação dos produtos esperados.

O espectro de IV dos produtos de epoxidação $(\mathbf{1 7}, \mathbf{1 8}, 19$ e $\mathbf{2 0})$ evidencia a formação dos produtos através do desaparecimento, ou diminuição da intensidade, da banda referente ao estiramento da ligação do alceno $(C=C)$, na região de aproximadamente em $3015 \mathrm{~cm}^{-1}$, bem como $\mathrm{o}$ aparecimento de uma banda pouco evidente em torno de $852 \mathrm{~cm}^{-1}$ que correspondem às vibrações da deformação do pequeno anel do epóxido. Observa-se ainda a diminuição da intensidade da banda referente à ligação $\mathrm{C}=\mathrm{C}$ substituídos na posição cis .

A formação de poli-álcoois no decorrer da cadeia carbônica $(\mathbf{2 5}, \mathbf{2 6}, 27$ e 28) é evidenciada pelo aparecimento de uma banda larga no espectro de IV na região de $3406 \mathrm{~cm}^{-1}$. Já a funcionalização da dupla ligação com mono ou di-éter $(21,22,23$ e 24) é caracterizada pelo 
aparecimento da banda em torno de $1097 \mathrm{~cm}^{-1}$ referente à ligação C-O de éter, além de manter o mesmo o sinal da ligação O-H de álcool.

A instauração dos nitro-derivados $(29$ - 45) foi comprovada pela diminuição da intensidade da banda referente à ligação $\mathrm{O}-\mathrm{H}$ de álcool em aproximadamente $3406 \mathrm{~cm}^{-1}$ no espectro de IV. Além da formação de banda referente ao estiramento antissimétrico forte em aproximadamente $1634 \mathrm{~cm}^{-1}$ e um simétrico de intensidade média em torno de $1275 \mathrm{~cm}^{-1}$. As bandas dos compostos nitrados revelaram certo deslocamento, quando comparado com a banda característica de grupamento nitro, que pode ser justificado pela presença da carbonila, que aumenta o efeito de hiperconjugação do sistema.

\subsubsection{Espectroscopia de Ressonância Magnética (RMN)}

Os espectros de Ressonância Magnética Nuclear de Hidrogênio $\left({ }^{1} \mathrm{H}\right.$ RMN) e de Carbono $\left({ }^{13} \mathrm{C}\right.$ RMN) foram simplificados nas Tabelas 4 e 5 , respectivamente, onde os deslocamentos químico de cada átomo encontra-se representado em partes por milhão (ppm). A fim de tornar esta discussão mais didática, os deslocamentos discutidos nos próximos tópicos serão referentes a um dos compostos, escolhidos aleatoriamente, já que há pelo menos quatro espectros muito parecidos entre si.

As Tabelas estão organizadas partindo de uma estrutura geral, cujos átomos de carbono encontram-se enumerados e os respectivos deslocamentos químicos respeitam tal numeração. A coloração identifica a sequiência metodológica, de modo que as colunas verdes trata-se dos intermediários e produtos advindos dos óleos de oliva e canola, respectivamente. As colunas em vermelho referem-se aos produtos e intermediários derivados do óleo de mamona e as azuis do óleo de soja. As colunas preenchidas com X referem-se a espectros que por algum motivo não foram obtidos, já as colunas marcadas com * tratam-se de compostos cuja determinação estrutural foi inconclusivo, devido a presença de possíveis misturas de compostos.

\subsubsection{Caracterização dos ésteres de partida}


Os oleatos de metila $(\mathbf{5}, \mathbf{6}, \mathbf{1 1}$ e 14) tiveram a calibragem das integrais na área correspondente ao singleto em aproximadamente $3,63 \mathrm{ppm}$, referente ao deslocamento dos hidrogênios do grupo metila ligado ao oxigênio do éster. Os espectros de hidrogênio e carbono dos biodieseis metílicos estão representados nos anexos 9, 10, 15, 16, 20 e 21.

No caso dos ésteres advindos do etilenoglicol (7, 8, 12 e 15), quando comparado com os espectros dos ésteres metílicos, observa-se o surgimento dos sinais entre 4,09 e 4,12 ppm nos espectros de ${ }^{1} \mathrm{H}$ RMN, referentes ao deslocamento químico de dois hidrogênios ligados a carbonos $\mathrm{sp}^{3}$. Pelos deslocamentos pode-se afirmar que há nas proximidades destes átomos grupo(s) retiradores de elétrons, confirmando assim a presença de dois $\mathrm{CH}_{2}$ ligados entre si e localizados entre o oxigênio de éster e de álcool. O espectro de ${ }^{13} \mathrm{C}$ RMN também confirma a formação deste produto, por meio do aparecimento dos picos em aproximadamente 62,1 e 68,9 ppm, referente aos mesmos carbonos. Esses espectros encontram-se nos anexos 11, 12, 17, 18.

Igualmente, os intermediários esterificados, derivados da glicerina $(9,10,13$ e 16) podem ter sua obtenção confirmada por meio do surgimentos de picos muito deslocados na região de aproximadamente $3,63-3,65 ; 3,54-3,67$ e 4,08 - 4,15 ppm. Tais deslocamentos referem-se aos três carbonos advindos da glicerina, onde o mais deslocado encontra-se ligado ao oxigênio do éster e os demais ligados ao oxigênio da hidroxila. Tais carbonos tem ainda sua existência confirmada pelo espectro de ${ }^{13} \mathrm{C}$ RMN por meio do aparecimento dos picos em cerca de 65,$1 ; 73,4$ e 70,3, onde, os dois primeiros estão ligados à hidroxila e o ultimo ao oxigênio do éster. Esses espectros encontram-se nos anexos 13, 14, 19, 22 e 23.

\subsubsection{Caracterização dos intermediários epoxidados}

A formação dos produtos epoxidados $(\mathbf{1 7}, \mathbf{1 8}, \mathbf{1 9}, \mathbf{2 0})$ é evidenciada também pelo aparecimento de um multipleto característico de acoplamento envolvendo os hidrogênios cis desblindados na faixa de 2.88 a 2.84 ppm nos espectros de ${ }^{1} \mathrm{H}$ RMN e 57,4 a 54,4 ppm nos espectros de ${ }^{13} \mathrm{C}$ RMN . Tais espectros encontram-se nos anexos 24, 25, 26, 27, 28, 29, 30 e 31.

A taxa de conversão das reações de epoxidação foi estimado a partir da conversão da (s) insaturação (ões), observada a partir do espectro de RMN de ${ }^{1} \mathrm{H}$. O cálculo foi realizado de acordo com a Equação 1, descrita a seguir, onde divide-se a relação da quantidade de hidrogênios (obtido 
pela subtração da integral dos hidrogênios desblindados da ligação $\mathrm{C}=\mathrm{C}$ nos produtos de partida pelos hidrogênios desblindados devido a presença do grupo epóxido) pela quantidade inicial dos mesmos. O valor obtido foi então multiplicado por 100, fornecendo assim o rendimento da reação. Abaixo a equação. A tabela 3 representa os rendimentos em \% dos derivados epoxidados caracterizados até o momento.

$$
\text { Convers } \tilde{a} \boldsymbol{o}=\frac{(\text { Hinicial })-(\text { Hfinal })}{(\text { Hinicial })} \times 100
$$

Equação 2: Fórmula para a obtenção da taxa de conversão.

\begin{tabular}{l|l}
\hline Epóxido & Conversão (\%) \\
\hline 17 & $\begin{array}{l}\text { Não pode ser calculado devido à falta de } \\
\text { caracterização }\end{array}$ \\
\hline 18 & 83,3 \\
\hline 19 & 28 \\
\hline 20 & 33 \\
\hline
\end{tabular}

Tabela 3:Conversão dos produtos epóxidados. FONTE: Próprio autor.

\subsubsection{Caracterização dos intermediários hidrolisados}

Há indícios para crer que os ésteres metílicos cuja(s) instauração(ões) foram funcionalizadas com pelo menos duas hidroxilas $(\mathbf{2 5}, \mathbf{2 6}, \mathbf{2 7}$ e 28) tenham sido obtidos em proporções muito pequenas. Supõe-se que tal fato tenha sido ocorrido pela ineficiência do ácido $p$ toluenossulfônico em protonar o oxigênio do anel oxiurânico. Neste sentido, acredita-se que pode haver uma mistura de compostos, conforme esquematizado no Esquema 10. 


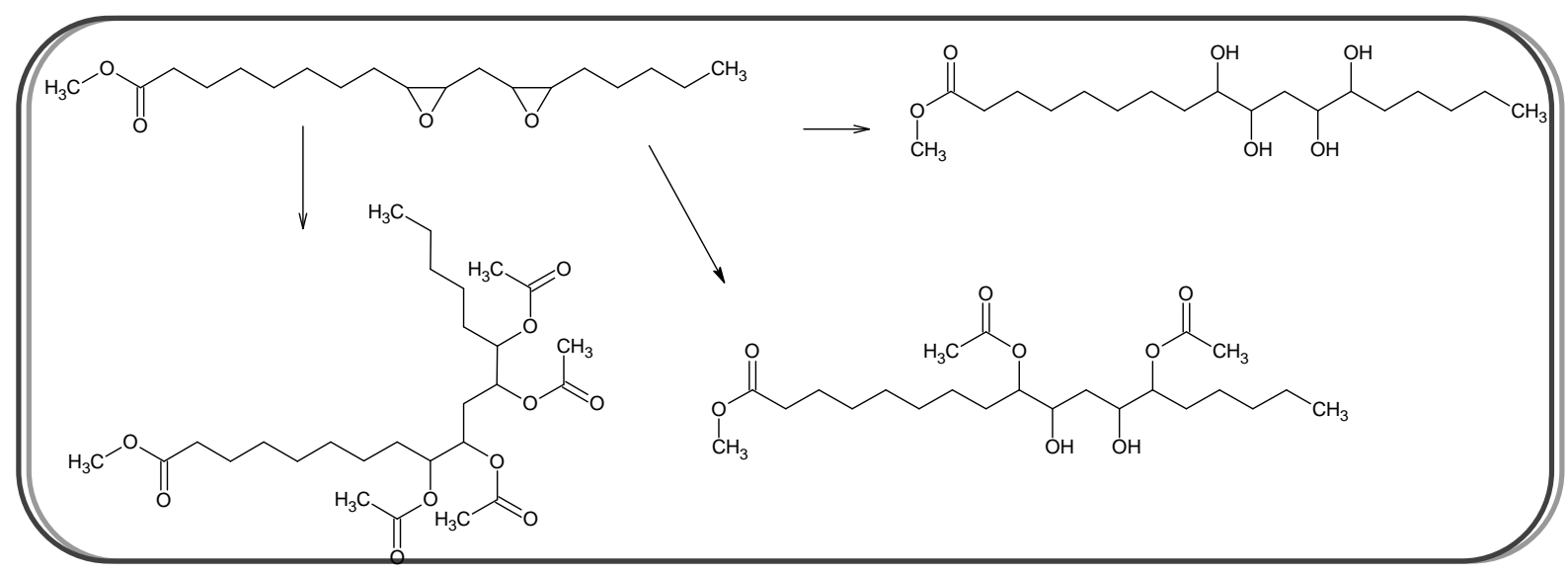

Esquema 2:Esquema genérico de prováveis produtos obtidos pela reação de hidrólise. FONTE: Próprio autor.

Tal suposição se dá pelos espectros de RMN, já que o deslocamento químico referente aos hidrogênios cujos carbonos estão ligados as hidroxilas deveriam estar evidentes na região de aproximadamente 3,53 um quarteto, nesta região aparece apenas alguns picos pouco perceptíveis como pode-se observar nos anexos 35, 36, 37 e 38 .

\subsubsection{Caracterização dos intermediários solvolisados}

Os intermediários solvolisados $(\mathbf{2 1}, \mathbf{2 2}, \mathbf{2 3}$ e 24) tiveram sua formação caracterizada pelo aparecimento de um singleto na região de 3,43 ppm no ${ }^{1} \mathrm{H}$ RMN e 58,09 ppm no ${ }^{13} \mathrm{C}$ RMN, que referem-se ao éter que funcionalizou a olefina. É considerado ainda o aumento do deslocamento dos hidrogênios ligados ao carbono funcionalizado com o álcool, que gira em torno de 3,37 ppm no ${ }^{1} \mathrm{H}$ RMN e aproximadamente $77,0 \mathrm{ppm}$ no ${ }^{13} \mathrm{C}$ RMN. Há ainda o surgimento de um singleto na região de 3,41 ppm referente ao hidrogênio do álcool.Os espectros destes compostos encontram-se nos anexos 32,33 e 34 .

Igualmente aos intermediários hidrolisados há indícios de mistura de compostos, como sugere o Esquema 11. 


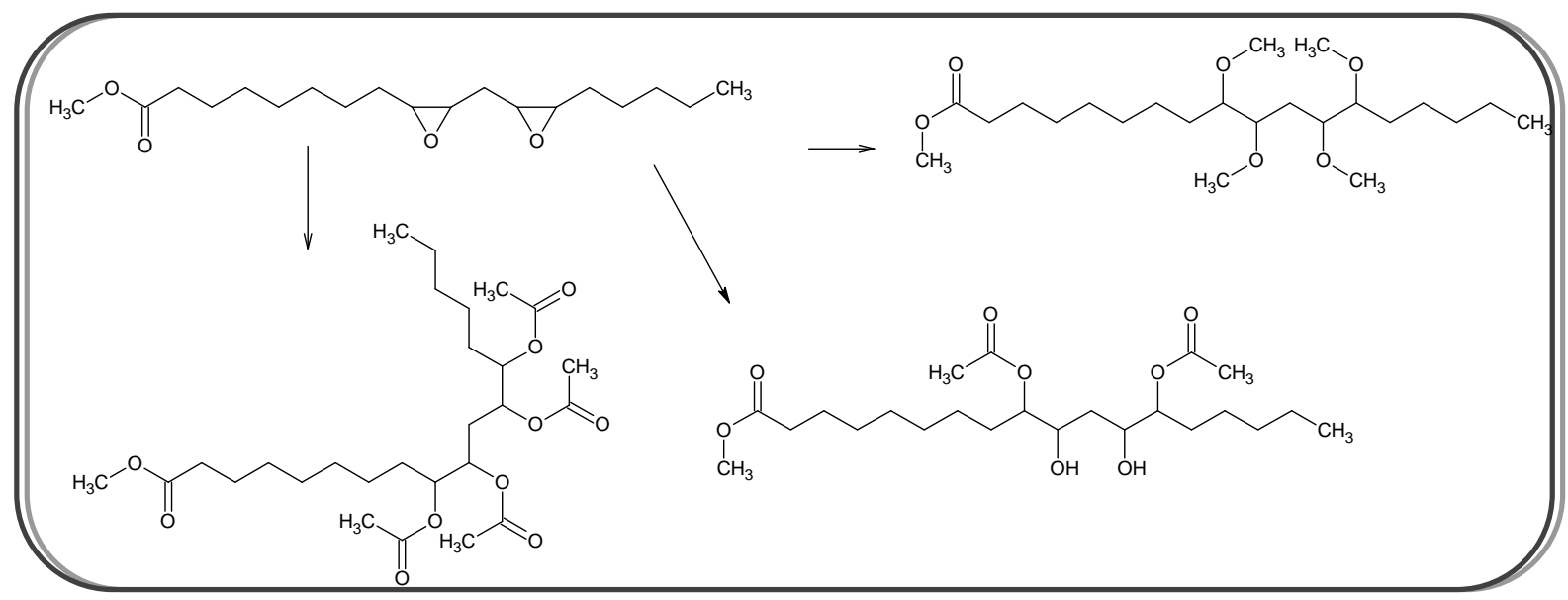

Esquema 11: Esquema genérico de prováveis produtos obtidos pela reação de solvólise. FONTE: Próprio autor.

\subsubsection{Caracterização dos produtos alvo}

Foram realizados espectros de ressonância magnética nuclear de hidrogênio e carbono para alguns dos nitrocompostos. E, por seu intermédio, é possível interpretar sua formação pelo deslocamento dos hidrogênios vizinhos ao grupo $\mathrm{ONO}_{2}$.

A formação dos nitro-compostos planejados com o etilenoglicol (7, 8, 12 e 15) é evidenciada através do aparecimento de dois multipletos em torno de $4 \mathrm{ppm}$ nos ${ }^{1} \mathrm{H}$ RMN e 65 ppm nos ${ }^{13} \mathrm{C}$ RMN, que referem-se, cada um, ao acoplamento de um par de hidrogênios localizados entre o grupo nitro e a carbonila. A proximidade com estes grupos retiradores de elétrons é a responsável pelo grande deslocamento dos picos. Entretanto, a presença do grupo funcional álcool no produto de partida também constitui um grupo que deslocaria os picos referentes ao grupo etileno localizado entre a carbonila e o grupo nitro. Logo, o deslocamento de tais hidrogênios cairia muito próximos, de modo que se os espectros estiverem representando o produto de partida (se não tiver ocorrido a reação) ou o nitro-derivado alvo não seria possível identificar com exatidão o produto concebido. Entretanto, estes espectros comprovam a formação do éster de partida, já que a negativa em torno da formação resultaria em picos não tão deslocados, já que não teriam a hidroxila. Tais espectros podem ser observados nos anexos 11, 12, 17 e 18 .

A formação dos nitroderivados planejados partindo-se da glicerina $(9,10,13$ e 16) foram evidenciados pelo aparecimento de dois multipletos, em torno de 3,7 e 3,8 ppm no espectro de ${ }^{1} \mathrm{H}$ $\mathrm{RMN}$, referentes ao acoplamento dos hidrogênios ligados aos carbonos $\mathrm{sp}^{3}$ localizados entre os respectivos nitros e o oxigênio do éster. Tais picos apresentaram um pequeno deslocamento em 
relação aos mesmos hidrogênios do material de partida (diferença de aproximadamente 1 ppm), comprovando assim a formação do produto. Tais espectros podem ser observados nos Anexos14, 19 e 22. Os espectros de ${ }^{13} \mathrm{C}$ RMN demonstraram-se inconclusivos para comprovar a formação do produto nitrado, já que não há diferença de deslocamento de picos, como observados nos Anexos 13 e 23.

A formação dos intermediários hidrolisados e solvolisados, planejados a partir dos respectivos ésteres metílicos, deu-se de maneira ineficiente, de modo a obter uma provável mistura de compostos, como descrito anteriormente, acredita-se que tais produtos finais também tenham sido obtidos na forma de mistura, conforme esquematizado a seguir. Portanto, os espectros de RMN de carbono e hidrogênio de tais compostos foram dados como inconclusivos, já que não é possível determinar uma estrutura exata.

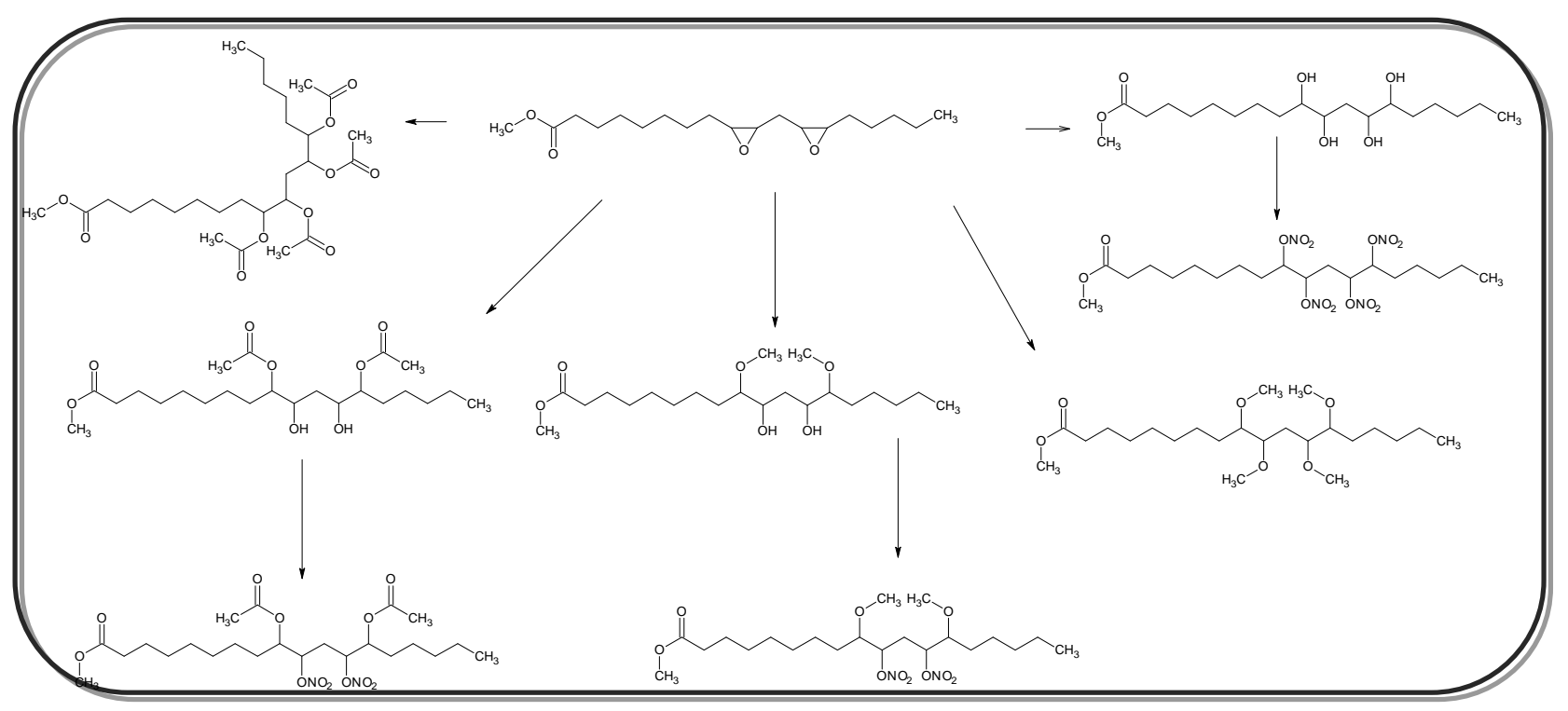

Esquema 12: Esquema genérico de prováveis produtos obtidos pela reação de nitração de intermediários derivados dos respectivos ésteres metílicos. FONTE: Próprio autor.

As Tabelas 4 e 5 utilizam a numeração apresentada no Esquema 13. 


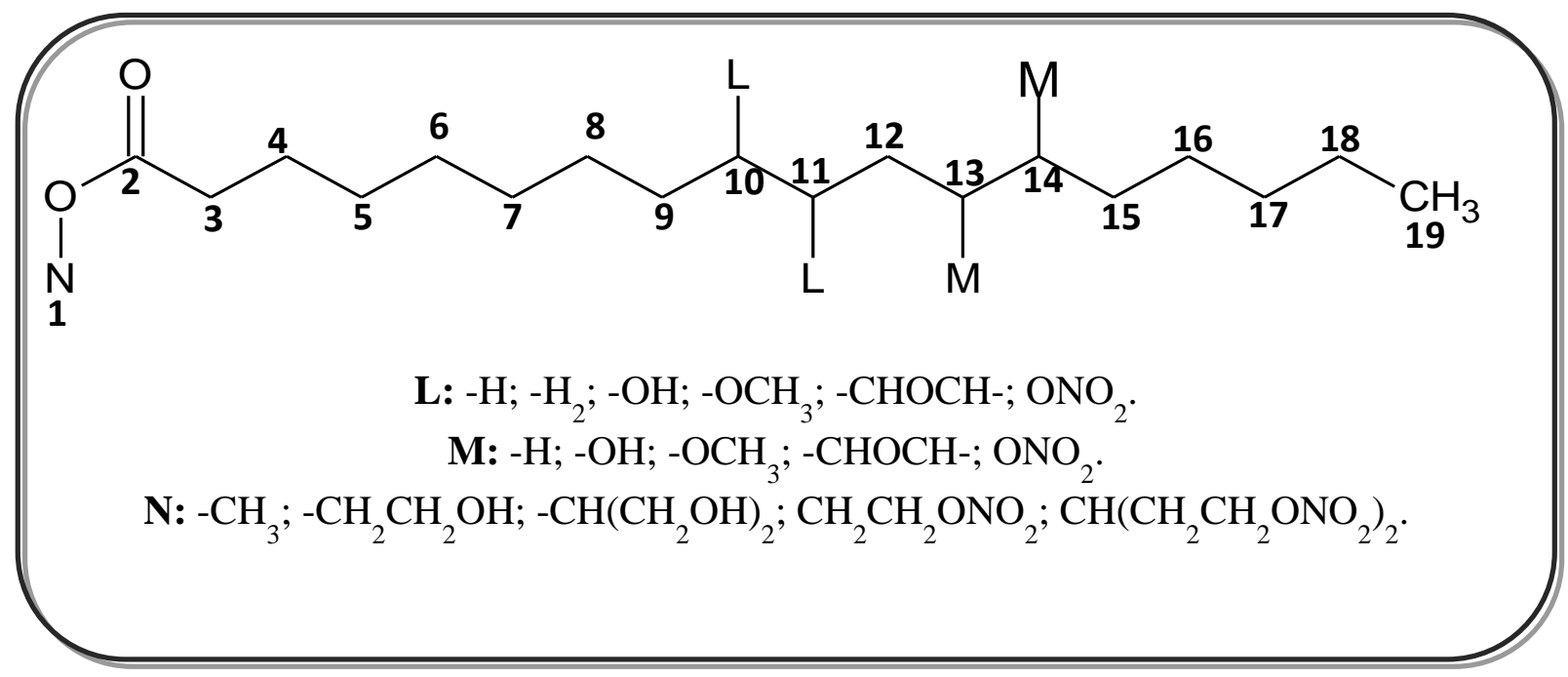

Esquema 13: Estrutura geral para análise das Tabelas de deslocamento químico. FONTE: Próprio autor. 


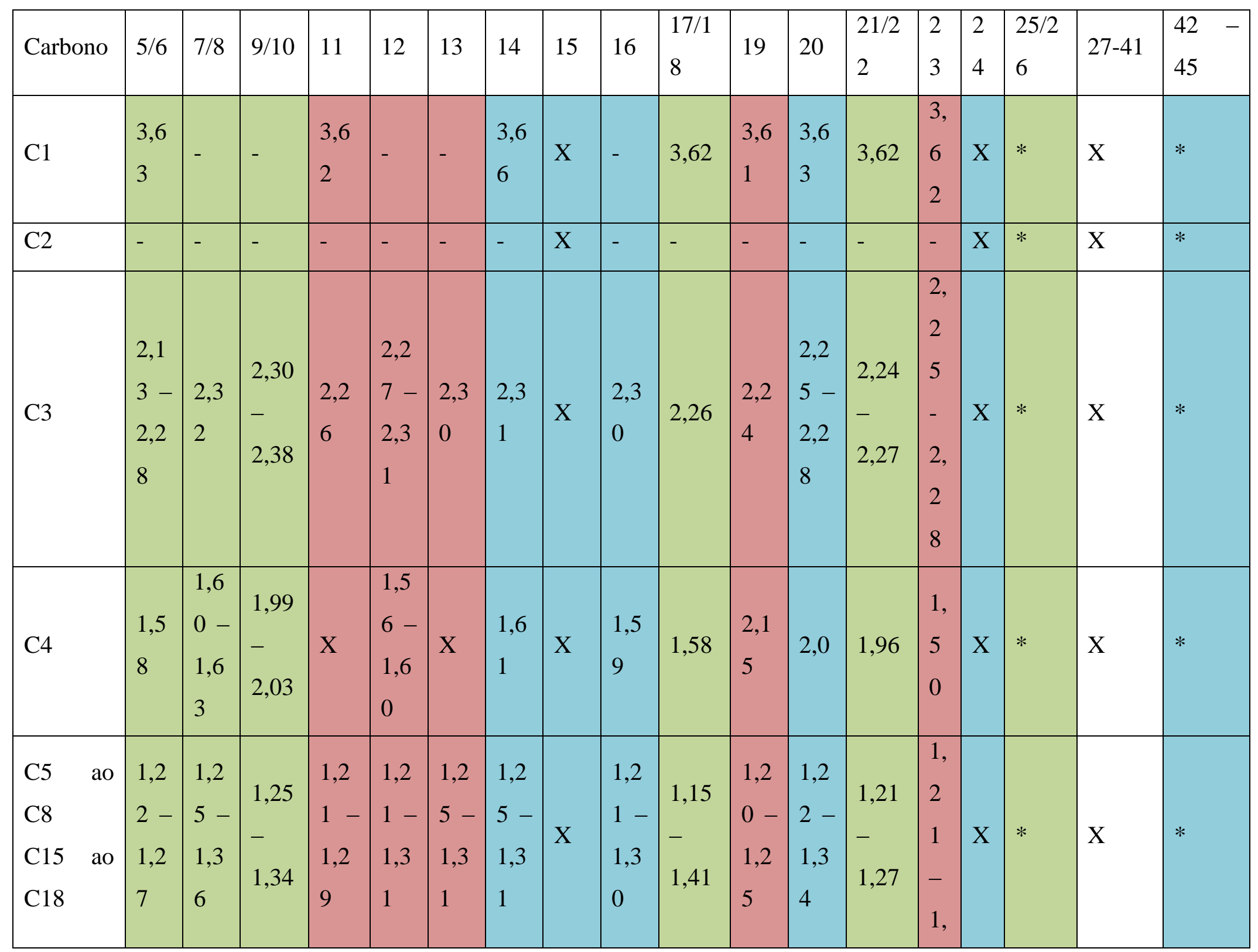




\begin{tabular}{|c|c|c|c|c|c|c|c|c|c|c|c|c|c|c|c|c|c|c|}
\hline & & & & & & & & & & & & & & $\begin{array}{l}2 \\
7\end{array}$ & & & & \\
\hline C9 & $\begin{array}{l}1,9 \\
7\end{array}$ & $\begin{array}{l}2,0 \\
- \\
2, \\
07\end{array}$ & $\begin{array}{l}1,60 \\
- \\
1,64\end{array}$ & $\begin{array}{l}5,3 \\
6\end{array}$ & $\begin{array}{l}2,1 \\
6\end{array}$ & $\begin{array}{l}2,1 \\
6\end{array}$ & $\begin{array}{l}2,0 \\
4\end{array}$ & $X$ & $\begin{array}{l}2,0 \\
0\end{array}$ & $\begin{array}{l}1,42 \\
- \\
1,48\end{array}$ & $\begin{array}{l}1,3 \\
9- \\
1,4 \\
2\end{array}$ & $\begin{array}{l}1,3 \\
6- \\
1,5 \\
2\end{array}$ & 1,57 & $\begin{array}{l}1, \\
5 \\
6\end{array}$ & $X$ & $*$ & $\mathrm{X}$ & $*$ \\
\hline $\mathrm{C} 10$ & $\begin{array}{l}5,3 \\
0\end{array}$ & $\begin{array}{l}5,3 \\
3- \\
5,5 \\
8\end{array}$ & $\begin{array}{l}5,31 \\
- \\
5,37\end{array}$ & $\begin{array}{l}5,5 \\
0- \\
5,5 \\
1\end{array}$ & $\begin{array}{l}5,3 \\
3- \\
5,3 \\
8\end{array}$ & $\begin{array}{l}5,5 \\
1\end{array}$ & $\begin{array}{l}5,3 \\
4- \\
5,3 \\
7\end{array}$ & $X$ & $\begin{array}{l}5,3 \\
0- \\
5,3 \\
3\end{array}$ & $\begin{array}{l}2,84 \\
- \\
3,09\end{array}$ & $\begin{array}{l}2,2 \\
6\end{array}$ & $\begin{array}{l}2,7 \\
2- \\
3,0 \\
9\end{array}$ & 3,37 & $\begin{array}{l}3, \\
3 \\
7\end{array}$ & $X$ & $*$ & $\mathrm{X}$ & $*$ \\
\hline C11 & $\begin{array}{l}5,3 \\
1\end{array}$ & $\begin{array}{l}5,3 \\
3- \\
5,3 \\
8\end{array}$ & $\begin{array}{l}5,31 \\
- \\
5,37\end{array}$ & $\begin{array}{l}2,0 \\
1\end{array}$ & $\begin{array}{l}5,4 \\
8- \\
5,5 \\
1\end{array}$ & $\begin{array}{l}5,3 \\
6\end{array}$ & $\begin{array}{l}5,3 \\
4- \\
5,3 \\
7\end{array}$ & $\mathrm{X}$ & $\begin{array}{l}5,3 \\
0- \\
5,3 \\
3\end{array}$ & $\begin{array}{l}2,84 \\
- \\
3,09\end{array}$ & $\begin{array}{l}2,2 \\
6\end{array}$ & $\begin{array}{l}2,7 \\
2- \\
3,0 \\
9\end{array}$ & 2,95 & $\begin{array}{l}3, \\
0 \\
7\end{array}$ & $X$ & $*$ & $\mathrm{X}$ & $*$ \\
\hline $\mathrm{C} 12$ & $\begin{array}{l}1,9 \\
7\end{array}$ & $\begin{array}{l}2,0 \\
- \\
2,0 \\
7\end{array}$ & $\begin{array}{l}1,99 \\
- \\
2,03\end{array}$ & $\begin{array}{l}3,2 \\
5\end{array}$ & $\begin{array}{l}1,9 \\
8- \\
2,0 \\
1\end{array}$ & $\begin{array}{l}2,0 \\
1\end{array}$ & $\begin{array}{l}2,3 \\
1\end{array}$ & $X$ & $\begin{array}{l}2,7 \\
3\end{array}$ & $\begin{array}{l}1,42 \\
- \\
1,48\end{array}$ & $\begin{array}{l}1,3 \\
9- \\
1,4 \\
2\end{array}$ & $\begin{array}{l}1,5 \\
7- \\
1,6 \\
1\end{array}$ & 1,57 & $\begin{array}{l}1, \\
5 \\
7\end{array}$ & $X$ & $*$ & $X$ & $*$ \\
\hline $\mathrm{C} 13$ & $\begin{array}{l}1,2 \\
2- \\
1,2 \\
7\end{array}$ & $\begin{array}{l}1,2 \\
5- \\
1,3 \\
6\end{array}$ & $\begin{array}{l}1,25 \\
- \\
1,34\end{array}$ & $\begin{array}{l}1,4 \\
3\end{array}$ & $\begin{array}{l}3,5 \\
7\end{array}$ & $\begin{array}{l}3,8 \\
8\end{array}$ & $\begin{array}{l}5,3 \\
4- \\
5,3 \\
7\end{array}$ & $X$ & $\begin{array}{l}5,3 \\
0- \\
5,3 \\
3\end{array}$ & $\begin{array}{l}1,15 \\
- \\
1,41\end{array}$ & $\begin{array}{l}3,3 \\
3\end{array}$ & $\begin{array}{l}1,1 \\
5- \\
1,4 \\
1\end{array}$ & $\begin{array}{l}1,21 \\
- \\
1,27\end{array}$ & $\begin{array}{l}3, \\
3 \\
7\end{array}$ & $X$ & $*$ & $X$ & $*$ \\
\hline
\end{tabular}




\begin{tabular}{|c|c|c|c|c|c|c|c|c|c|c|c|c|c|c|c|c|c|c|}
\hline C14 & $\begin{array}{l}1,2 \\
2- \\
1,2 \\
7\end{array}$ & $\begin{array}{l}1,2 \\
5- \\
1,3 \\
6\end{array}$ & $\begin{array}{l}1,25 \\
- \\
1,34\end{array}$ & $\begin{array}{l}1,2 \\
5\end{array}$ & $\begin{array}{l}4,2 \\
2\end{array}$ & $\begin{array}{l}1,5 \\
8\end{array}$ & $\begin{array}{l}5,3 \\
4- \\
5,3 \\
7\end{array}$ & $X$ & $\begin{array}{l}5,3 \\
0- \\
5,3 \\
3\end{array}$ & $\begin{array}{l}1,15 \\
- \\
1,41\end{array}$ & $\begin{array}{l}1,9 \\
6- \\
2,0 \\
1\end{array}$ & $\begin{array}{l}1,1 \\
5- \\
1,4 \\
1\end{array}$ & $\begin{array}{l}1,21 \\
- \\
1,27\end{array}$ & $\begin{array}{l}1, \\
5 \\
7\end{array}$ & $\mathrm{X}$ & $*$ & $X$ & $*$ \\
\hline C19 & $\begin{array}{l}0,8 \\
4\end{array}$ & $\begin{array}{l}0,8 \\
7- \\
0,9 \\
1\end{array}$ & $\begin{array}{l}0,87 \\
- \\
0,89\end{array}$ & $\begin{array}{l}0,8 \\
4\end{array}$ & $\begin{array}{l}0,8 \\
4\end{array}$ & $\begin{array}{l}0,8 \\
4\end{array}$ & $\begin{array}{l}0,8 \\
8\end{array}$ & $X$ & $\begin{array}{l}0,8 \\
5\end{array}$ & 0,85 & $\begin{array}{l}0,8 \\
3\end{array}$ & $\begin{array}{l}0,8 \\
9\end{array}$ & 0,83 & $\begin{array}{l}0, \\
8 \\
3\end{array}$ & $\mathrm{X}$ & $*$ & $X$ & $*$ \\
\hline $\begin{array}{l}\mathrm{COOC} \underline{\mathrm{H}} \\
{ }_{2} \mathrm{CH}_{2} \mathrm{OH}\end{array}$ & - & $\begin{array}{l}4,1 \\
4- \\
4,3 \\
0\end{array}$ & - & & $\begin{array}{l}4,1 \\
6\end{array}$ & - & - & $X$ & - & - & - & - & - & - & $\mathrm{X}$ & $*$ & $X$ & $*$ \\
\hline $\begin{array}{l}\mathrm{COOCH} \\
{ }_{2} \mathrm{C}_{2} \mathrm{OH}\end{array}$ & & $\begin{array}{l}4,1 \\
4- \\
4,3 \\
0\end{array}$ & & & $\begin{array}{l}3,7 \\
7\end{array}$ & & - & $X$ & - & - & & - & - & - & $\mathrm{X}$ & $*$ & $X$ & $*$ \\
\hline $\begin{array}{l}\mathrm{COOC} \underline{\mathrm{H}} \\
\left(\mathrm{CH}_{2} \mathrm{OH}\right. \\
)_{2}\end{array}$ & & - & $\begin{array}{l}4,1 \\
- \\
4,2\end{array}$ & & - & $\begin{array}{l}4,1 \\
0\end{array}$ & - & $X$ & $\begin{array}{l}4,1 \\
3\end{array}$ & - & - & - & - & - & $\mathrm{X}$ & $*$ & $X$ & $*$ \\
\hline $\begin{array}{l}\mathrm{COOCH} \\
\left(\mathrm{CH}_{2} \mathrm{OH}\right. \\
)_{2}\end{array}$ & - & - & $\begin{array}{l}4,1 \\
- \\
4,2\end{array}$ & & - & $\begin{array}{l}3,6 \\
4\end{array}$ & - & $X$ & $\begin{array}{l}3,5 \\
6- \\
3,6\end{array}$ & - & - & - & - & - & $\mathrm{X}$ & $*$ & $X$ & $*$ \\
\hline
\end{tabular}




\begin{tabular}{|l|l|l|l|l|l|l|l|l|l|l|l|l|l|l|l|l|l|}
\hline & & & & & & & & & 4 & & & & & & & & \\
\hline
\end{tabular}

Tabela 4: Deslocamento químico dos hidrogênios, obtidos por meio dos espectros de ${ }^{1}$ HRMN. FONTE: Próprio autor. 


\begin{tabular}{|c|c|c|c|c|c|c|c|c|c|c|c|c|c|c|c|c|c|c|}
\hline Carbono & $5 / 6$ & $7 / 8$ & $9 / 10$ & 11 & 12 & 13 & 14 & 15 & 16 & $\begin{array}{l}17 / 1 \\
8\end{array}$ & 19 & 20 & $\begin{array}{l}21 / 2 \\
2\end{array}$ & $\begin{array}{l}2 \\
3\end{array}$ & $\begin{array}{l}2 \\
4\end{array}$ & $\begin{array}{l}25 / 2 \\
6\end{array}$ & $\begin{array}{l}27 \\
41\end{array}$ & $\begin{array}{ll}42 & - \\
45 & \end{array}$ \\
\hline $\mathrm{C} 1$ & $\begin{array}{l}51, \\
4\end{array}$ & - & - & $\begin{array}{l}51, \\
4\end{array}$ & - & $X$ & $\begin{array}{l}51, \\
4\end{array}$ & $X$ & - & 51,4 & $\begin{array}{l}51, \\
6\end{array}$ & $\begin{array}{l}51, \\
6\end{array}$ & 51,4 & $X$ & $X$ & $*$ & $X$ & $*$ \\
\hline $\mathrm{C} 2$ & $\begin{array}{l}17 \\
4,3\end{array}$ & $\begin{array}{l}17 \\
3,2\end{array}$ & - & $\begin{array}{l}17 \\
4,3\end{array}$ & $\begin{array}{l}17 \\
4,2\end{array}$ & $X$ & $\begin{array}{l}17 \\
4,3\end{array}$ & $X$ & $\begin{array}{l}17 \\
3,8\end{array}$ & $\begin{array}{l}174, \\
2\end{array}$ & $\begin{array}{l}17 \\
3,1\end{array}$ & $\begin{array}{l}17 \\
4,4\end{array}$ & $\begin{array}{l}174, \\
3\end{array}$ & $X$ & $\mathrm{X}$ & $*$ & $X$ & $*$ \\
\hline $\mathrm{C} 3$ & $\begin{array}{l}13 \\
4,1\end{array}$ & $\begin{array}{l}34, \\
2\end{array}$ & $\begin{array}{l}174, \\
3\end{array}$ & $\begin{array}{l}31, \\
8\end{array}$ & $\begin{array}{l}34, \\
1\end{array}$ & $X$ & $\begin{array}{l}34, \\
1\end{array}$ & $X$ & $\begin{array}{l}34, \\
1\end{array}$ & 34,0 & $\begin{array}{l}37, \\
6\end{array}$ & $\begin{array}{l}34, \\
3\end{array}$ & 34,1 & $X$ & $X$ & $*$ & $X$ & $*$ \\
\hline $\mathrm{C} 4$ & $\begin{array}{l}24, \\
9\end{array}$ & $\begin{array}{l}24, \\
8\end{array}$ & 34,1 & $\begin{array}{l}24, \\
9\end{array}$ & $\begin{array}{l}24, \\
8\end{array}$ & $X$ & $\begin{array}{l}27, \\
2\end{array}$ & $X$ & $\begin{array}{l}24, \\
8\end{array}$ & 24,9 & $\begin{array}{l}29, \\
9- \\
29, \\
7\end{array}$ & $\begin{array}{l}25, \\
2\end{array}$ & $\begin{array}{l}29,1 \\
- \\
29,8\end{array}$ & $X$ & $X$ & $*$ & $X$ & $*$ \\
\hline $\begin{array}{ll}\mathrm{C} 5 & \text { ao } \\
\mathrm{C} 8 & \\
\mathrm{C} 15 & \text { ao } \\
\mathrm{C} 18 & \end{array}$ & $\begin{array}{l}29, \\
2- \\
29, \\
7\end{array}$ & $\begin{array}{l}22, \\
7- \\
31, \\
9\end{array}$ & $\begin{array}{l}29,3 \\
- \\
29,8\end{array}$ & $\begin{array}{l}25, \\
7- \\
29, \\
5\end{array}$ & $\begin{array}{l}22, \\
5- \\
31, \\
8\end{array}$ & $X$ & $\begin{array}{l}29, \\
2- \\
31, \\
5\end{array}$ & $X$ & $\begin{array}{l}24, \\
8- \\
29, \\
3\end{array}$ & $\begin{array}{l}22,6 \\
- \\
24,9\end{array}$ & $\begin{array}{l}29, \\
9- \\
29, \\
7\end{array}$ & $\begin{array}{l}26, \\
8- \\
29 \\
9\end{array}$ & $\begin{array}{l}29,1 \\
- \\
29,8\end{array}$ & $X$ & $\mathrm{X}$ & $*$ & $X$ & $*$ \\
\hline C9 & $\begin{array}{l}27, \\
2\end{array}$ & $\begin{array}{l}34, \\
0\end{array}$ & 27,2 & $\begin{array}{l}34, \\
0\end{array}$ & $\begin{array}{l}33, \\
6\end{array}$ & $X$ & $\begin{array}{l}31, \\
6\end{array}$ & $X$ & $\begin{array}{l}31, \\
8\end{array}$ & 31,9 & $\begin{array}{l}69, \\
3\end{array}$ & $\begin{array}{l}26, \\
8- \\
29, \\
9\end{array}$ & $\begin{array}{l}76,8 \\
- \\
77,3\end{array}$ & $X$ & $X$ & $*$ & $\mathrm{X}$ & $*$ \\
\hline $\mathrm{C} 10$ & $\begin{array}{l}13 \\
0,0\end{array}$ & $\begin{array}{l}13 \\
0,2\end{array}$ & $\begin{array}{l}130, \\
0\end{array}$ & $\begin{array}{l}12 \\
5,2\end{array}$ & $\begin{array}{l}12 \\
5,2\end{array}$ & $X$ & $\begin{array}{l}13 \\
0,2\end{array}$ & $X$ & $\begin{array}{l}13 \\
0,1\end{array}$ & 57,1 & $\begin{array}{l}51, \\
4\end{array}$ & $\begin{array}{l}57, \\
4\end{array}$ & 84,3 & $X$ & $X$ & $*$ & $\mathrm{X}$ & $*$ \\
\hline
\end{tabular}




\begin{tabular}{|c|c|c|c|c|c|c|c|c|c|c|c|c|c|c|c|c|c|c|}
\hline C11 & $\begin{array}{l}12 \\
9,7\end{array}$ & $\begin{array}{l}12 \\
9,7\end{array}$ & $\begin{array}{l}129, \\
7\end{array}$ & $\begin{array}{l}13 \\
3,3\end{array}$ & $\begin{array}{l}13 \\
3,2\end{array}$ & $X$ & $\begin{array}{l}12 \\
8,3\end{array}$ & $X$ & $\begin{array}{l}12 \\
7,8\end{array}$ & 57,2 & $\begin{array}{l}46, \\
3\end{array}$ & $\begin{array}{l}56, \\
7\end{array}$ & 1,6 & $X$ & $X$ & $*$ & $X$ & $*$ \\
\hline $\mathrm{C} 12$ & $\begin{array}{l}27, \\
2\end{array}$ & $\begin{array}{l}22, \\
7- \\
31, \\
9\end{array}$ & 27,2 & $\begin{array}{l}36 \\
8\end{array}$ & $\begin{array}{l}36 \\
8\end{array}$ & $X$ & $\begin{array}{l}22, \\
57\end{array}$ & $X$ & $\begin{array}{l}31, \\
5\end{array}$ & 31,8 & $\begin{array}{l}72, \\
3\end{array}$ & $\begin{array}{l}25, \\
1\end{array}$ & $\begin{array}{l}29,1 \\
- \\
29,8\end{array}$ & $X$ & $X$ & $*$ & $X$ & $*$ \\
\hline $\mathrm{C} 13$ & $\begin{array}{l}29, \\
2\end{array}$ & $\begin{array}{l}22, \\
7- \\
31, \\
9\end{array}$ & $\begin{array}{l}29,3 \\
- \\
29,8\end{array}$ & $\begin{array}{l}71, \\
5\end{array}$ & $\begin{array}{l}71, \\
5\end{array}$ & $X$ & $\begin{array}{l}12 \\
8,3\end{array}$ & $X$ & $\begin{array}{l}13 \\
0,1\end{array}$ & $\begin{array}{l}22,6 \\
- \\
24,9\end{array}$ & $\begin{array}{l}38, \\
2\end{array}$ & $\begin{array}{l}54, \\
4\end{array}$ & $\begin{array}{l}29,1 \\
- \\
29,8\end{array}$ & $X$ & $X$ & $*$ & $X$ & $*$ \\
\hline $\mathrm{C} 14$ & $\begin{array}{l}29, \\
7\end{array}$ & $\begin{array}{l}22, \\
7- \\
31, \\
9\end{array}$ & $\begin{array}{l}29,3 \\
- \\
29,8\end{array}$ & $\begin{array}{l}35, \\
3\end{array}$ & $\begin{array}{l}35, \\
6\end{array}$ & $X$ & $\begin{array}{l}13 \\
0,2\end{array}$ & $X$ & $\begin{array}{l}12 \\
7,8\end{array}$ & $\begin{array}{l}22,6 \\
- \\
24,9\end{array}$ & $\begin{array}{l}29, \\
9- \\
29, \\
7\end{array}$ & $\begin{array}{l}51, \\
6\end{array}$ & $\begin{array}{l}29,1 \\
- \\
29,8\end{array}$ & $X$ & $X$ & $*$ & $X$ & $*$ \\
\hline C19 & $\begin{array}{l}14, \\
09\end{array}$ & $\begin{array}{l}14, \\
1\end{array}$ & 14,1 & $\begin{array}{l}14, \\
0\end{array}$ & $\begin{array}{l}14, \\
0\end{array}$ & $X$ & $\begin{array}{l}14, \\
1\end{array}$ & $X$ & $\begin{array}{l}14, \\
01\end{array}$ & 14,0 & $\begin{array}{l}14, \\
0\end{array}$ & $\begin{array}{l}14, \\
2\end{array}$ & 14,1 & $X$ & $X$ & $*$ & $X$ & $*$ \\
\hline $\begin{array}{l}\mathrm{COOC} \underline{\mathrm{H}} \\
{ }_{2} \mathrm{CH}_{2} \mathrm{OH}\end{array}$ & & $\begin{array}{l}68, \\
9\end{array}$ & - & & $\begin{array}{l}65 \\
8\end{array}$ & $X$ & - & $X$ & - & - & - & - & - & $X$ & $X$ & $*$ & $X$ & $*$ \\
\hline $\begin{array}{l}\mathrm{COOCH} \\
{ }_{2} \mathrm{C}_{2} \mathrm{OH}\end{array}$ & & $\begin{array}{l}62, \\
1\end{array}$ & - & & $\begin{array}{l}63, \\
6\end{array}$ & $X$ & - & $X$ & - & - & - & - & - & $X$ & $X$ & $*$ & $X$ & $*$ \\
\hline $\begin{array}{l}\mathrm{COOC} \underline{\mathrm{H}} \\
\left(\mathrm{CH}_{2} \mathrm{OH}\right.\end{array}$ & & - & 70,3 & & - & $X$ & - & $X$ & $\begin{array}{l}70, \\
2\end{array}$ & - & - & - & - & $X$ & $X$ & $*$ & $X$ & $*$ \\
\hline
\end{tabular}




\begin{tabular}{|c|c|c|c|c|c|c|c|c|c|c|c|c|c|c|c|c|}
\hline$)_{2}$ & & & & & & & & & & & & & & & & \\
\hline $\begin{array}{l}\mathrm{COOCH} \\
\left(\mathrm{C}_{2} \mathrm{OH}\right. \\
)_{2}\end{array}$ & - & $\begin{array}{l}63,4 \\
- \\
65,1\end{array}$ & - & $X$ & - & $X$ & $\begin{array}{l}65 \\
0\end{array}$ & - & - & - & - & $X$ & $\mathrm{X}$ & $*$ & $X$ & $*$ \\
\hline
\end{tabular}

Tabela 5: Deslocamento químico dos carbonos, obtidos por meio dos espectros de ${ }^{13}$ CRMN. FONTE: Próprio autor. 


\subsection{Avaliações de Número de Cetano Derivado}

A influencia dos nitro-compostos sintetizados no número de cetano do diesel pode ser observada através da Tabela 6, onde foi avaliado o diesel B (diesel aditivado com biodiesel). Esta mistura foi preparada respeitando a proporção de 7\% em volume, de acordo com a legislação vigente. Em seguida procedeu-se a aditivação da mesma mistura com diferentes nitroderivados, possibilitando a comparação e análise da influência da quantidade de grupos nitros na cadeia carbônica e em sua extremidade.

\begin{tabular}{l|l}
\hline Produto & Número de Cetano \\
\hline Diesel B & 53.41 \\
\hline 30 & 56.75 \\
\hline 42 & 56.82 \\
\hline 43 & 55.18 \\
\hline 44 & 52.87 \\
\hline 45 & 52.52 \\
\hline Tabela 6: Número de cetano de nitroderivados.. FONTE: Próprio autor.
\end{tabular}

A referência (diesel B) revelou o valor de 53,41. Assim, os compostos 30, 42 e 43 revelaram menor atraso de ignição, portanto, apresentaram significativa melhora no NC, otimizando em 3,34, 3,41 e 1,77 pontos para o NC, respectivamente. Assim as definições estabelecidas pela ANP (Resolução $n^{\circ} 30$ de 23 de junho de 2016) foram respeitadas. Tais documentações regulamentam, por sua vez que o NC deve ser igual ou superior a 48 para motores movidos a diesel S-10, já que um longo atraso de ignição (NC inferior a 48) provoca um acúmulo de combustível não queimado na câmara que, ao passar pela auto ignição tardia, ocasiona aumento brusco de pressão, provocando um ruído chamado de batida diesel. (Brasília, 2016). Entretanto, há relatos na literatura que este valor não deve ultrapassar 60, pois resulta em combustão quase que imediata, podendo gerar danos mecânicos ao veiculo, como a redução de potência e fadiga dos elementos mecânicos. (Szklo; Uller, 2008). 
Dentre todos, os compostos 30 e $\mathbf{4 2}$ demostraram melhores resultados, que podem ser justificados pela presença de metoxila(s) que funcionalizaram as cadeias carbônicas dos ácidos oléico e linoléico, respectivamente, juntamente com o(s) grupo(s) nitro(s). É sabido que a metoxila é um radical retirador de elétrons, devido à presença do oxigênio, que é um átomo muito eletronegativo, assim, ao distorcer a densidade eletrônica ocorre uma maior suscetibilidade da ruptura da ligação carbono-oxigênio, facilitando assim a reação de combustão.

Em contrapartida, os compostos funcionalizados apenas nas extremidades das cadeias $(44 \mathrm{e}$ 45), mostraram diminuição no NC. Tal diminuição pode ser explicada pela ausência de grupos nitros no meio da cadeia e a presença de insaturações, de modo que a ruptura de uma ligação entre carbonos $\mathrm{sp}^{2}$ necessita de maior demanda energética, quando comparada à ligação entre carbonos $\mathrm{sp}^{3}$, dificultando assim a formação de produtos da combustão.

\subsection{Avaliações Microbiológicas}

Foram realizados testes microbiológicos frente a fungos (Aspergillusniger $\mathrm{e}$ Aspergillusfumigattus) e bactérias (Bacillussubtillis e Acinetobactersp). Tais microorganismos foram escolhidos baseados nos trabalhos de Silva, Suarez e Rangel, 2015, que identificaram tais microorganismos em maior evidência em combustíveis comercializados nos postos de combustíveis do Distrito federal. Os ensaios foram realizados plaqueando blendas de nitrocomposto/diesel S-10 na concentração de $1 \%(\mathrm{~m} / \mathrm{m})$. Findado o período de uma semana, as placas de ensaio foram analisadas e por fim, constatados os halos de inibição, de acordo com a Tabela 7. As mesmas placas foram fotografadas e exemplificadas na Figura 5, para fungo e bactéria, respectivamente.

Os microorganismos testados foram escolhidos por serem comuns em contaminação de biodiesel. Por meio destes testes, foi possível comprovar a ineficiência do diesel S-10 frente a fungos e bactérias, podendo então ser utilizado como controle negativo. Observou-se ainda, que nenhuma das blendas apresentou atividade bactericida e/ou bacteriostática, para ambas as bactérias. Algumas blendas apresentaram potencial halo de inibição frente a fungos, considerando que compostos atendidos como biologicamente ativos devem apresentar halos de inibição igual ou superior a $10 \mathrm{~mm}$. Fora ainda observada contaminação de todas as placas de ensaio, plaqueadas com fungos, excetuando-se nas proximidades dos compostos 31, 34, 35, 39, 43, 44 e 45 , 
considerados, por sua vez ativos. Os compostos enumerados na Figura 5 não seguem a mesma sequência numérica, assim, os compostos ativos citados acima correspondem aos halos de inibição $15,2,16,17,5$ e 9 , respectivamente.

\begin{tabular}{|c|c|c|c|c|}
\hline & \multicolumn{2}{|c|}{ Fungos } & \multicolumn{2}{|c|}{ Bactérias } \\
\hline Amostras & $\begin{array}{c}A . \\
\operatorname{niger}(\mathrm{mm})\end{array}$ & $\begin{array}{c}A . \\
\text { fumigattus }(\mathrm{mm})\end{array}$ & Bacillussubtillis(mm) & Acinetobactersp (mm) \\
\hline $\begin{array}{c}\text { Diesel s- } \\
10\end{array}$ & - & - & - & - \\
\hline 29 & - & - & - & - \\
\hline 30 & - & - & - & - \\
\hline 31 & 11,33 & 10,00 & - & - \\
\hline 32 & - & - & - & - \\
\hline 33 & - & - & - & - \\
\hline 34 & 14 & 11,33 & - & - \\
\hline 35 & - & 10,33 & - & - \\
\hline 36 & - & - & - & - \\
\hline 37 & - & - & - & - \\
\hline 38 & - & - & - & - \\
\hline 39 & 16,33 & 14,50 & - & - \\
\hline 40 & - & - & - & - \\
\hline 41 & - & - & - & - \\
\hline 42 & - & - & - & - \\
\hline 43 & 25,00 & 13,66 & - & - \\
\hline 44 & 12,33 & 10,33 & - & - \\
\hline 45 & 21,33 & 12,50 & - & - \\
\hline
\end{tabular}

Tabela 7: Resultados dos ensaios microbiológicos frente à fungos e bactérias. FONTE: Próprio autor. 
A

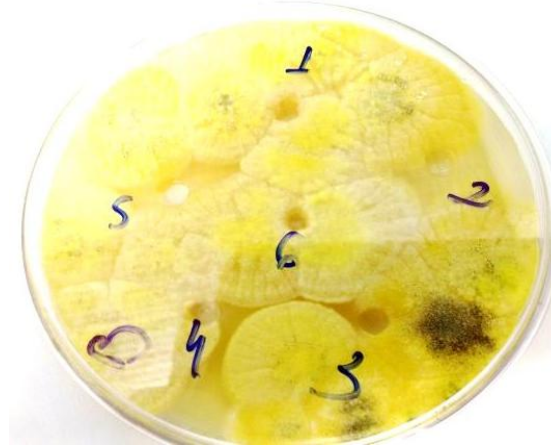

D

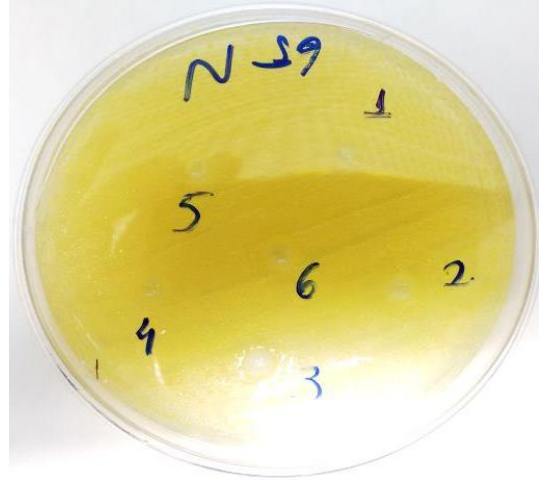

B

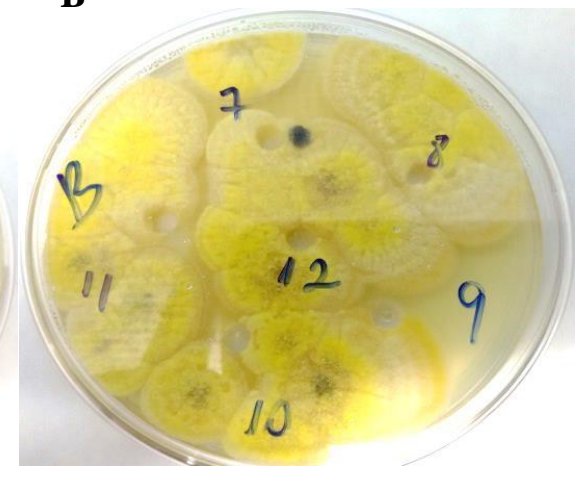

$\mathbf{E}$

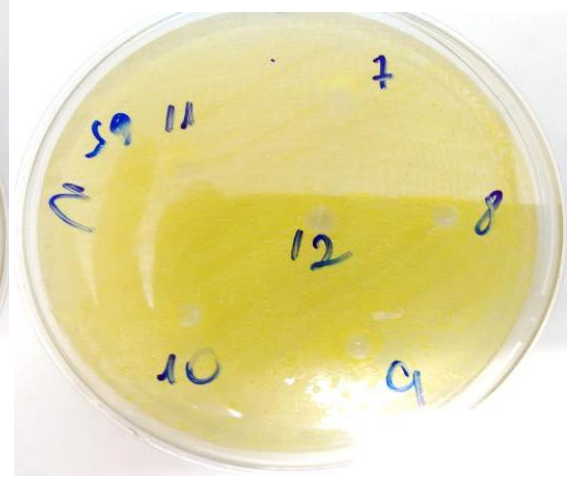

C

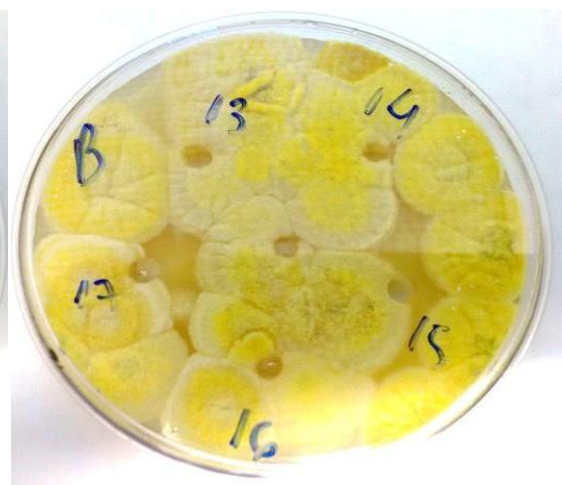

$\mathbf{F}$

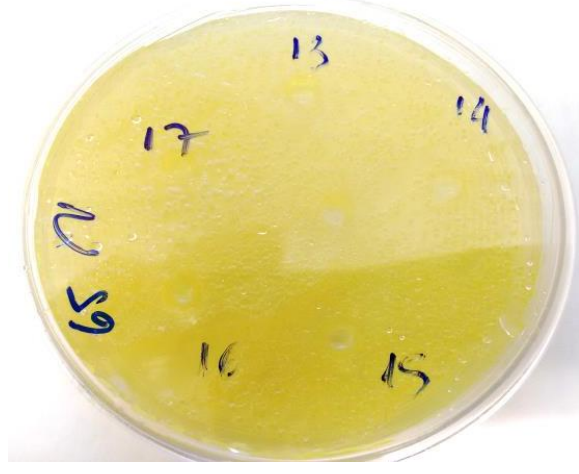

Figura 3: Fotografia das placas de ensaio. A, B e C frente ao fungo. D, E e F frente a bactéria. FONTE: Próprio autor.

\subsection{Testes de Estabilidade à Oxidação}

Os testes de estabilidade à oxidação foram realizados verificando o tempo em horas que o composto examinado oxida sob condições de exposição ao ar e à temperatura $\left(110^{\circ} \mathrm{C}\right)$. De modo que, quanto maior o tempo gasto para atingir $200 \mathrm{~S}$, mais estável o composto é. Portanto, quanto mais instável, provavelmente melhor será o potencial antioxidante, assim, o composto oxida, protegendo assim o biodiesel, de modo que deva aumentar a vida útil do biocombustível. Para certificar-se que a teoria está correta, deve ser realizado testes comparando o tempo de oxidação do biodiesel puro, do antioxidante puro, bem como das blendas em diferentes concentrações, a fim 
de verificar a concentração mínima necessária para que ocorra o retardo na oxidação da mistura. Os testes com as blendas constituem uma das perspectivas deste trabalho.

A tabela a seguir revela que o tempo de indução (TI) dos compostos testados. Onde a referência é o biodiesel metílico de soja, que possui um alto teor de ésteres de ácidos graxos insaturados, que o torna sensível à degradação oxidativa, conduzindo-o a um baixo período de indução, de $0,17 \mathrm{~h}$. Os nitroderivados descritos na tabela foram submetidos a teste de estabilidade oxidativa no Rancimat® na concentração de 100\%. Os compostos 33, 34, 36, 38 e 45 revelaram um tempo de indução superior ao B100, que nos induz a pensar que devam atuar como bons aditivos antioxidantes. Como não foram testados na forma de blenda, os compostos 34, 38 e 55 que apresentaram uma melhora discreta não devem alcançar o TI mínimo de $6 \mathrm{~h}$ estabelecidos pela ANP. Entretanto, os compostos 33 e 36 revelaram uma melhora significativa, de pelo menos 6 horas de TI, assim, é previsto que atuem como excelentes antioxidantes.

\begin{tabular}{c|c}
\hline Amostra & Tempo de indução (h) \\
\hline $\mathbf{1 4}$ & 0,17 \\
\hline $\mathbf{3 3}$ & $>6$ \\
\hline $\mathbf{3 4}$ & 1,21 \\
\hline $\mathbf{3 6}$ & 6,00 \\
\hline $\mathbf{3 8}$ & 0,22 \\
\hline $\mathbf{4 1}$ & 0 \\
\hline $\mathbf{4 2}$ & 0 \\
\hline $\mathbf{4 3}$ & 0 \\
\hline $\mathbf{4 5}$ & 0,30
\end{tabular}

Tabela 8: Tempo de oxidação de alguns dos nitrocompostos na concentração de $100 \%$. FONTE: Próprio autor

\subsection{Caracterização Físico-Química}

A Tabela 9 demonstra que as blendas preparadas com os nirocompostos e diesel S-10 e biodiesel não comprometeram, no geral as determinações estabelecidas pela ANP, que prevê que a 
viscosidade deve estar entre 3,0 e 6,0 $\mathrm{mm}^{2} / \mathrm{s}$ e a densidade entre 875 e $900 \mathrm{~g} / \mathrm{cm}^{3}$ (Resolução $\mathrm{n}^{\circ} 45$ de 25 de agosto de 2014).. 


\begin{tabular}{|c|c|c|c|c|}
\hline Amostra & Solvente & Concentração & $\begin{array}{l}\text { Densidade a } \\
40^{\circ} \mathrm{C} \\
\left(\mathrm{g} / \mathrm{cm}^{3}\right)\end{array}$ & $\begin{array}{l}\text { Viscosidade } \\
\text { Cinemática a } \\
40^{\circ} \mathrm{C}\left(\mathrm{mm}^{2} / \mathrm{s}\right)\end{array}$ \\
\hline \multirow{8}{*}{29} & \multirow{4}{*}{$\begin{array}{l}\text { Diesel S- } \\
10\end{array}$} & $0,25 \%$ & 0,8295 & 3,1911 \\
\hline & & $0,50 \%$ & 0,8296 & 3,2012 \\
\hline & & $0,75 \%$ & 0,8299 & 3,225 \\
\hline & & $1 \%$ & 0,8303 & 3,2115 \\
\hline & \multirow{4}{*}{ Biodiesel } & $0,25 \%$ & 0,8715 & 3,9591 \\
\hline & & $0,50 \%$ & 0,8714 & 3,9771 \\
\hline & & $0,75 \%$ & 0,8717 & 3,9784 \\
\hline & & $1 \%$ & 0,8718 & 4,0131 \\
\hline \multirow{3}{*}{30} & \multirow{3}{*}{$\begin{array}{l}\text { Diesel S- } \\
10\end{array}$} & $0,25 \%$ & 0,8332 & 3,0741 \\
\hline & & $0,50 \%$ & 0,8296 & 3,2079 \\
\hline & & $0,75 \%$ & 0,8299 & 3,2218 \\
\hline
\end{tabular}

\begin{tabular}{|c|c|c|c|c|}
\hline & & $1 \%$ & 0,8303 & 3,2395 \\
\hline & & $0,25 \%$ & & \\
\hline & & $0,50 \%$ & & \\
\hline & & $0,75 \%$ & & \\
\hline & & $1 \%$ & & \\
\hline & & $0,25 \%$ & 2,7215 & 0,8213 \\
\hline & Diesel S- & $0,50 \%$ & 2,7361 & 0,8219 \\
\hline & 10 & $0,75 \%$ & 2,7283 & 0,822 \\
\hline & & $1 \%$ & 2,7427 & 0,8222 \\
\hline & & $0,25 \%$ & 0,8671 & 4,4168 \\
\hline & & $0,50 \%$ & 0,8673 & 4,2466 \\
\hline & & $0,75 \%$ & 0,8669 & 4,2421 \\
\hline & & $1 \%$ & 0,8676 & 4,2818 \\
\hline 32 & Diesel S- & $0,25 \%$ & & \\
\hline
\end{tabular}




\begin{tabular}{|c|c|c|c|c|}
\hline & 10 & $0,50 \%$ & & \\
\hline & & $0,75 \%$ & & \\
\hline & & $1 \%$ & & \\
\hline & & $0,25 \%$ & & \\
\hline & & $0,50 \%$ & & \\
\hline & & $0,75 \%$ & & \\
\hline & & $1 \%$ & & \\
\hline & & $0,25 \%$ & 0,8332 & 3,0741 \\
\hline & Diesel S- & $0,50 \%$ & 0,8296 & 3,2079 \\
\hline & 10 & $0,75 \%$ & 0,8299 & 3,2218 \\
\hline 33 & & $1 \%$ & 0,8303 & 3,2395 \\
\hline & & $0,25 \%$ & & \\
\hline & Biodiesel & $0,50 \%$ & & \\
\hline & & $0,75 \%$ & & \\
\hline
\end{tabular}

\begin{tabular}{|c|c|c|c|c|}
\hline & & $1 \%$ & & \\
\hline \multirow{8}{*}{34} & \multirow{4}{*}{$\begin{array}{l}\text { Diesel S- } \\
10\end{array}$} & $0,25 \%$ & 0,8295 & 3,1911 \\
\hline & & $0,50 \%$ & 0,8296 & 3,2012 \\
\hline & & $0,75 \%$ & 0,8299 & 3,225 \\
\hline & & $1 \%$ & 0,8303 & 3,2115 \\
\hline & \multirow{4}{*}{ Biodiesel } & $0,25 \%$ & 0,8715 & 3,9591 \\
\hline & & $0,50 \%$ & 0,8714 & 3,9771 \\
\hline & & $0,75 \%$ & 0,8717 & 3,9784 \\
\hline & & $1 \%$ & 0,8718 & 4,0131 \\
\hline \multirow{5}{*}{35} & \multirow{4}{*}{$\begin{array}{l}\text { Diesel S- } \\
10\end{array}$} & $0,25 \%$ & 0,8217 & 2,7277 \\
\hline & & $0,50 \%$ & 0,8219 & 2,708 \\
\hline & & $0,75 \%$ & 0,8223 & 2,7365 \\
\hline & & $1 \%$ & 0,8224 & 2,7362 \\
\hline & \begin{tabular}{|l|} 
Biodiesel \\
\end{tabular} & $0,25 \%$ & 0,8668 & 4,1956 \\
\hline
\end{tabular}




\begin{tabular}{|c|c|c|c|c|}
\hline & & $0,50 \%$ & 0,8668 & 4,2105 \\
\hline & & $0,75 \%$ & 0,8672 & 4,2646 \\
\hline & & $1 \%$ & 0,8675 & 4,2838 \\
\hline & & $0,25 \%$ & 2,7421 & 0,8218 \\
\hline & Diesel S- & $0,50 \%$ & 2,7408 & 0,8218 \\
\hline & 10 & $0,75 \%$ & 2,7702 & 0,822 \\
\hline & & $1 \%$ & 2,7649 & 0,8223 \\
\hline & & $0,25 \%$ & 0,867 & 4,2615 \\
\hline & & $0,50 \%$ & 0,8673 & 4,2793 \\
\hline & & $0,75 \%$ & 0,8675 & 4,2648 \\
\hline & & $1 \%$ & 0,8675 & 4,3192 \\
\hline & & $0,25 \%$ & & \\
\hline 37 & Diesel S- & $0,50 \%$ & & \\
\hline & & $0,75 \%$ & & \\
\hline
\end{tabular}

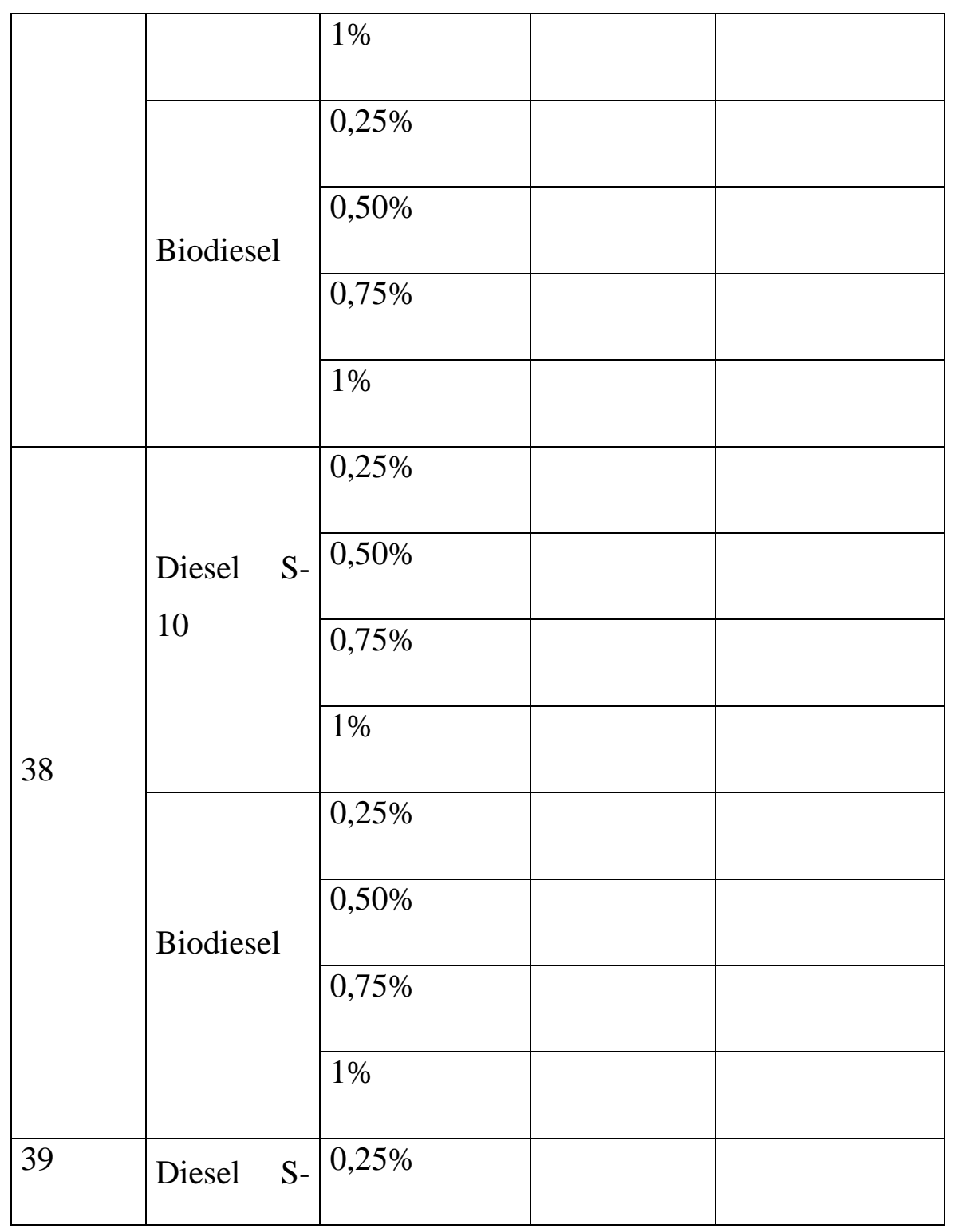




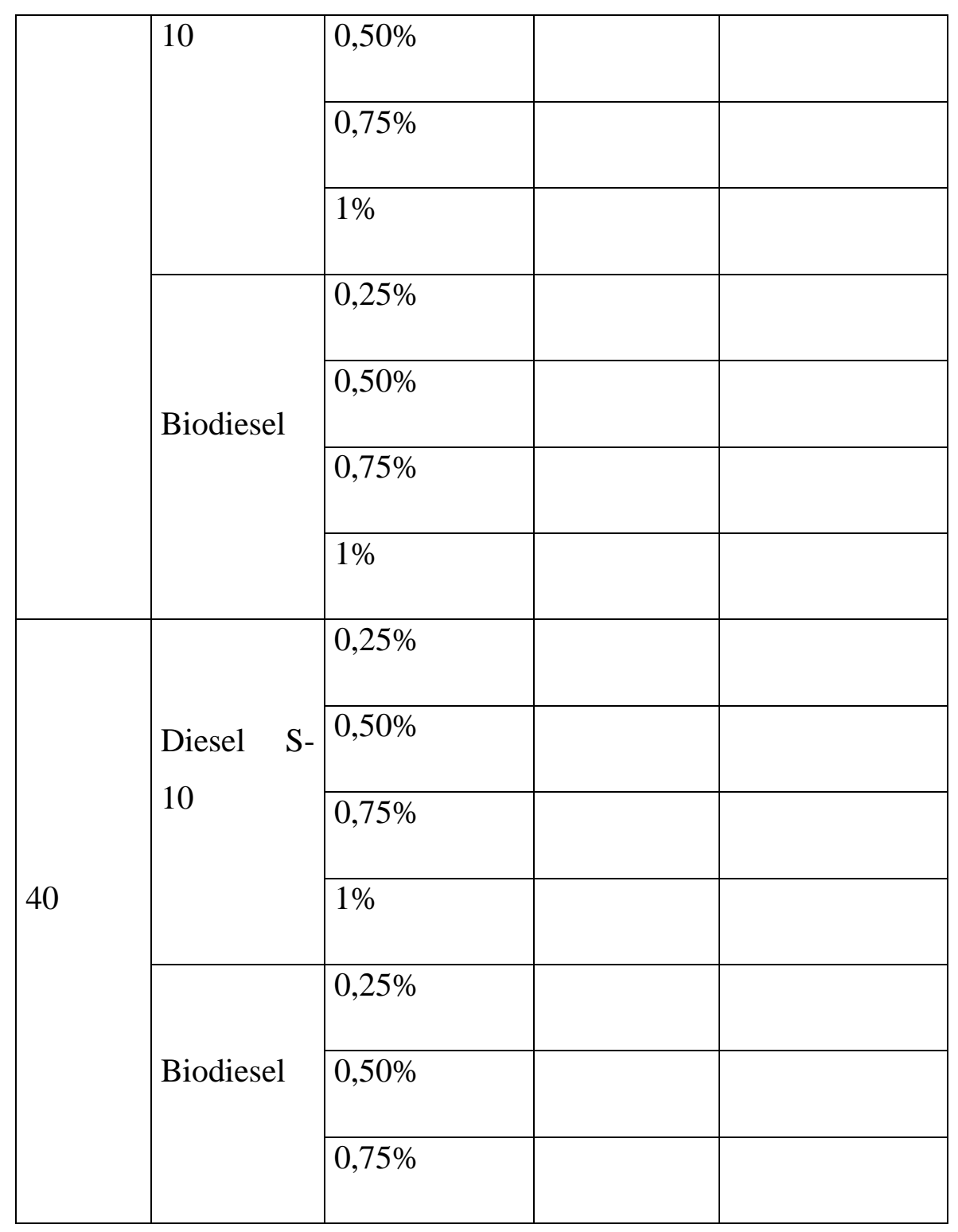

\begin{tabular}{|c|c|c|c|c|}
\hline & & $1 \%$ & & \\
\hline \multirow{8}{*}{41} & \multirow{4}{*}{$\begin{array}{l}\text { Diesel S- } \\
10\end{array}$} & $0,25 \%$ & 0,8213 & 2,7236 \\
\hline & & $0,50 \%$ & 0,8203 & 2,689 \\
\hline & & $0,75 \%$ & 0,8213 & 2,7206 \\
\hline & & $1 \%$ & 0,8214 & 2,7427 \\
\hline & \multirow{4}{*}{ Biodiesel } & $0,25 \%$ & 0,8671 & 4,2661 \\
\hline & & $0,50 \%$ & 0,8669 & 4,2595 \\
\hline & & $0,75 \%$ & 0,865 & 4,1268 \\
\hline & & $1 \%$ & 0,8648 & 4,1336 \\
\hline \multirow{5}{*}{42} & \multirow{4}{*}{$\begin{array}{l}\text { Diesel S- } \\
10\end{array}$} & $0,25 \%$ & & \\
\hline & & $0,50 \%$ & & \\
\hline & & $0,75 \%$ & & \\
\hline & & $1 \%$ & & \\
\hline & Biodiesel & $0,25 \%$ & & \\
\hline
\end{tabular}




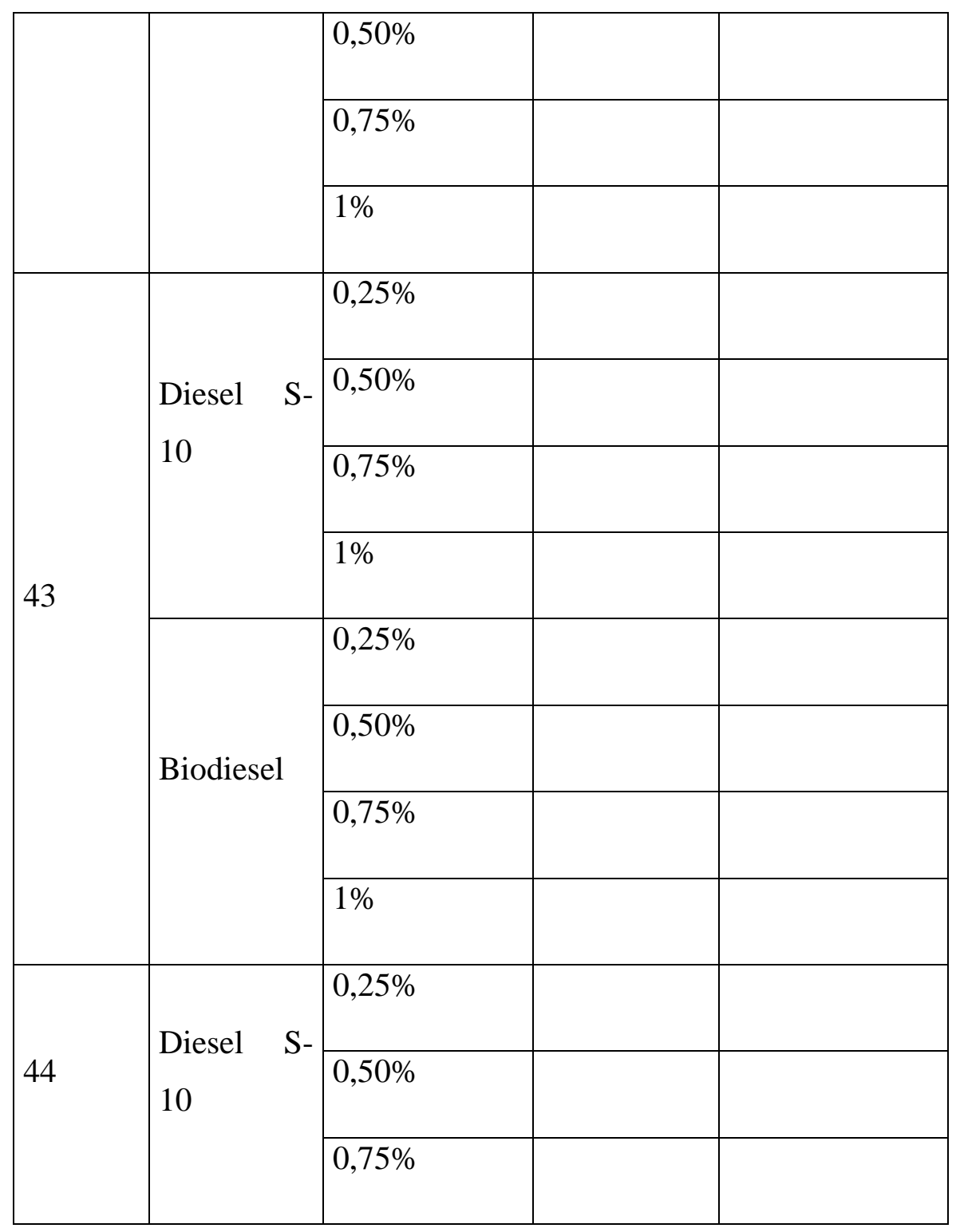

\begin{tabular}{|c|c|c|c|c|}
\hline & & $1 \%$ & & \\
\hline & & $0,25 \%$ & & \\
\hline & & $0,50 \%$ & & \\
\hline & & $0,75 \%$ & & \\
\hline & & $1 \%$ & & \\
\hline & & $0,25 \%$ & 0,8217 & 2,6866 \\
\hline & Diesel $\mathrm{S}$ & $0,50 \%$ & 0,8219 & 2,7284 \\
\hline & 10 & $0,75 \%$ & \begin{tabular}{|l|}
0,8222 \\
\end{tabular} & 2,7219 \\
\hline & & $1 \%$ & & \\
\hline & & $0,25 \%$ & 0,867 & 4,2547 \\
\hline & & $0,50 \%$ & \begin{tabular}{|l|}
0,8372 \\
\end{tabular} & 4,2399 \\
\hline & & $0,75 \%$ & 0,8674 & 4,2806 \\
\hline & & $1 \%$ & 0,8677 & 4,3022 \\
\hline
\end{tabular}

Tabela 9: Resultado dos testes físico-químicos. FONTE: Próprio autor. 
CONCLUSÕES E PERSPECTIVAS 


\section{CONCLUSÕES E PERSPECTIVAS}

De modo geral os produtos e intermediários foram obtidos e caracterizados satisfatoriamente por meio de IV, ${ }^{1} \mathrm{H}$ RMN e ${ }^{13} \mathrm{C}$ RMN, apesar de prevê-se a presença de mistura em nitratos advindos de ésteres metílicos. Os compostos 30, 42 e 43 revelaram melhora significativa no número de cetano derivado, quando comparado com o diesel S-10, respeitando as especificações estabelecidas pela ANP. Os testes microbiológicos elucidaram a não reatividade de nitroderivados frente a bactérias, pelo contrário, aparentemente favorecem a contaminação fúngica, entretanto, os compostos 31, 34, 39, 43, 44 e 45, na concentração de $1 \%$, revelaram atividade biocida ou biostática frente a fungos, exibindo halos de inibição que variam entre 10 e 25 mm. Com relação aos testes de estabilidade oxidativa os compostos 33 e 36 apresentaram potencial antioxidante, na concentração de $100 \%$, já que o tempo de indução obtido foi, para ambos, no mínimo de 6 h. Os testes físico-químicos revelaram que as blendas dos nitroderivados com biodiesel e diesel S-10 respeitaram as especificações estabelecidas pela ANP para densidade e viscosidade. Há na literatura indícios que levam a crer que os nitroderivados obtidos neste

trabalho apresentem possível características para atuar como lubrificantes, os testes que confirmam esta hipótese constitui a perspectiva deste trabalho. 
REFERENCIAL BIBLIOGRÁFICO 


\section{REFERENCIAL BIBLIOGRÁFICO}

Agência Nacional de Petróleo. Produção de Biodiesel (m3). Disponível em: <http://dados.gov.br/dataset/biodiesel-producao>. Acesso em: 19 set. 2015.

AGENCIA NACIONAL DE PETRÓLEO. Resolução $\mathrm{n}^{\circ}$ 11.097, de 13 de janeiro de 2005. Resolução Anp No 45. Brasília, DF, 28 ago. 2014.

AGÊNCIA NACIONAL DE PETRÓLEO (ANP). Constituição (2016). Resolução no 30, de 23 de junho de 2016. Resolução Anp $\mathrm{N}^{\circ}$ 30. Brasília, DF, 24 jun. 2016. Disponível em: <http://nxt.anp.gov.br/NXT/gateway.dll?f=templates\&fn=default.htm\&vid=anp:10.1048/enu> . Acesso em: 11 ago. 2016.

ANP. Anuário Estatístico Brasileiro do Petróleo, Gás Natural e Biocombustíveis 2011. Agência Nacional do Petróleo, Gás Natural e Biocombustíveis - ANP. Rio de Janeiro, 2011.

OUAD, N. El; BENHARREF, A.; GREE, R.. Facile and efficient synthesis of $3 \beta$-hydroxyeupholanost-8-en- 24-one.Molecules, França, v. 1, n. 6, p.468-471, abr. 2001.

BRASIL. MINISTÉRIO DA AGRICULTURA, PECUÁRIA E ABASTACIMENTO. . Soja. Disponível em: <http://www.agricultura.gov.br/vegetal/culturas/soja〉. Acesso em: 29 ago. 2015.

BRASIL. BANCO NACIONAL DO DESENVOLVIMENTO BNDS. . Potencial de Diversificação da Indústria Química Brasileira: Relatório 3 : Oleoquímicos. Rio de Janeiro: Ministério do Desenvolvimento, Indústria e Comercio Exterior, 2014.

BARCZA, Marcos Villela. Nitração. Disponível em: <http://www.dequi.eel.usp.br/ barcza/Nitracao.pdf>. Acesso em: 16 set. 2015.

BRASÍLIA. AGêNCIA NACIONAL DE PETRÓLEO. . Características do óleo diesel. Disponível em: <http://www.br.com.br/wps/portal/portalconteudo/produtos/paraembarcacoes/oleodiesel/!ut/p/c4/0 4_SB8K8xLLM9MSSzPy8xBz9CP0os3hLf0N_P293QwMLD383A6MgbwNLE0MjAyDQL8h2 VAQA9k0JIQ!!/?PC_7_9O1ONKG108HOF02RK094120003000000_WCM_CONTEXT=/wps/w $\mathrm{cm} /$ connect/portal+de+conteudo/produtos/automotivos/oleo+diesel/caracteristica+do+oleo>. Acesso em: 28 ago. 2016. 
Bento, F.M., Englert, G.E., Gaylarde, C.C., Muller, I.L., 2004. Influence of aqueous phase on electrochemical biocorrosion tests in diesel/water systems. Materials andCorrosion 55, 577e585

BIGGS, J.; CHAPMAN, N. B.; WRAY, V.. Mechanism of Acid-catalysedAlcoholysis of Epoxides: Part 1V.1 Methanolysis of D( +)-,2(-EIpoxyethyl) benzene. J. Chem. Soc. (b), 1971: Phys. Org., Hull, v. 1, n. 1, p.71-74, jan. 1971.

BÜCKER, Francielle et al. Impact of biodiesel on biodeterioration of stored Brazilian diesel oil. International Biodeterioration\& Biodegradation, [s.1.], v. 65, n. 1, p.172-178, jan. 2011. Elsevier BV. DOI: 10.1016/j.ibiod.2010.09.008.

CANOIRA, Laureano et al. Nitration of biodiesel of waste oil: Nitrated biodiesel as a cetane number enhancer. Fuel, [s.1.], v. 86, n. 7-8, p.965-971, maio 2007. Elsevier BV. http://dx.doi.org/10.1016/j.fuel.2006.10.022.

Dunn R. O and G. Knothe, Oxidative stability of biodiesel in blends with jet fuel by analysis of oil stability index, Journal of American Oil Chemist; 80(2003), 1047-8.

FARIA, IvanDutra et al. A Utilização de Óleo Vegetal Refinado como Combustível: Aspectos Legais, Técnicos, Econômicos, Ambientais e Tributários. Brasília: Centro de Estudos da Consultoria do Senado Federal, 2010. 64 p.

GENOVESEI, Alex Leão; UDAETAII, Miguel Edgar Morales; GALVAOII, Luiz Cláudio Ribeiro. Aspectos energéticos da biomassa como recurso no Brasil e no mundo. An. 6. Enc. Energ. Meio Rural 2006, São Paulo, v. 1, n. 6, p.1-10, mar. 2006.

PINTO, Ana Teresa. O que a Globalização está fazendo com o Planeta?: Avanços tecnológicos; impactos na educação e resgate da identidade cultural. Disponível em: <http://www.fsma.edu.br/visoes/ed03/3ed_artigo2.pdf>. Acesso em: 29 ago. 2015.

LEITE, Ana Carolina Gomes Moreira; GUEVARA, Arnoldo José de Hoyos. A SUSTENTABILIDADE EMPRESARIAL, SOCIAL E AS FONTES DE ENERGIAS. 2013. 55 f. TCC (Graduação) - Curso de Administração, Pontíficia Universidade Católica de São Paulo, São Paulo, 2013.

LOPES, Wilson Araújo; FASCIO, Miguel. Esquema para interpretação de espectros de substâncias orgânicas na região do infra-vermelho. Quim. Nova, Salvador, v. 27, n. 4, p.670-673, maio 2004. 
Maria J.R., M.F. Carmen, C. Abraham, R. Lourdes and P. Angel, Influence of fatty acid composition of raw materials on biodiesel properties, Bioresource Technology, 100(1) (2009), 261-268.

MARTinS, G. B. C; MEllo, V. M.; ZSUAREZ, P. A.. Processos Térmicos em Óleos e Gorduras. Rev. Virtual Quim., Brasília, v. 1, n. 5, p.16-21, 18 jan. 2013

MASIERO, Gilmar; LOPES, Heloisa. Etanol e biodiesel como recursos energéticos alternativos: perspectivas da América Latina e da Ásia. Rev. Bras. Polít. Int., Brasília, v. 2, n. 51, p.60-79, jul. 2008.

MELO, Marco Aurélio Rodrigues de. Monitoramento da estabilidade oxidativa no armazenamento de biodiesel metílico de soja/ mamona e blendas em recipientes de vidro. 2009. 95 f. Dissertação (Mestrado) - Curso de Química, Universidade Federal da Paraíba, João Pessoa, 2009.

Ministério de Minas e Energia. Programa Nacional de Produção e uso do Biodiesel. Disponível em: <http://www.mme.gov.br/programas/biodiesel/menu/biodiesel/pnpb.html>. Acesso em: 10 set. 2015 .

NDANA, M. et al. Effect of Storage on Stability of Biodiesel Produced from Selected Seed Oils. Int. J. Pure Appl. Sci. Technol, Kontogora - Nigéria, v. 1, n. 13, p.10-18, 25 set. 2012.

Olah, G. A.; Ripudaman, M.; Narang, S. C. Nitration,Methods and Mechanisms; VCH: New York, 1989.

OLIVEIRA, Flavia C. C.; SUAREZ, Paulo A. Z.; SANTOS, Wildson L. P. dos. Biodiesel: Possibilidades e Desafios. Química Nova na Escola, Brasília, v. 1, n. 28, p.3-8, maio 2008.

OLIVEIRA, Renato Santana de. Conversão catalítica heterogênea de biodiesel de soja epoxidado via reação de acetoxilação: síntese e caracterização de novos produtos com potencial aplicação como aditivos. 2013. 69 f. Dissertação (Mestrado) - Curso de Química, Universidade de Brasília, Brasília, 2013.

Oliveira, Vanda Maria de. Líquidos iônicos como meio na modificação de ésteres de ácidos (graxos) via aminólise catalítica e na síntese de nanopartículas magnéticas. 2011. 131 f. Tese (Doutorado) - Curso de Química, Universidade de Brasília, Brasília, 2011. 
PACHECO, Fabiana. Energias Renováveis: breves conceitos. Conjuntura e Planejamento, Salvador, v. 1, n. 149, p.4-11, out. 2006.

PEDROZO, Tiago Hommerding. "ÉSTERES ETÍLICOS EPOXIDADOS DO ÓLEO DE Milho COMO PLASTIFicANTE ALTERNATivo PARA O PVC. 2009. 82 f. Tese (Doutorado) - Curso de Química, Universidade Federal do ParanÁ, Curitiba, 2009.

Poirier, M. A.; Steere, D. E.; Krogh, J. A. Cetane Improver Compositions Comprising Nitrated Fatty Acid Derivatives. U.S.Patent 5,454,842. 1995.

RAMALHO, Hugo de Farias. Síntese de novos derivados de biodiesel de soja via reação de carbonilação em sistema bifásico. 2010. xi, 55 f. il. Dissertação (Mestrado em Química)Universidade de Brasília, Brasília, 2010.

RIOS, J.1.; RECIO, M.c.; VILLAR, A..Screening methods for natural products with antimicrobial activity: A review of the literature. Journal OfEthnopharmacology, [s.1.], v. 23, n. 2-3, p.127149, jul. 1988. Elsevier BV. DOI: 10.1016/0378-8741(88)90001-3. Disponível em: $<$ http://api.elsevier.com/content/article/PII:0378874188900013?httpAccept=text/xml>. Acesso em: 16 set. 2015 .

SALDANA, D. A.; STARCK L.; MOUGIN, P.; ROUSSEAU, B.; PIDOL, L.; JEULAND N.; CRETON, B. Flash Point and Cetane Number Predictions for Fuel Compounds Using Quantitative Structure Property Relationship (QSPR) Methods. Energy Fuels. v. 25, p. 3900-3908, 2011.

SCHUCHARDT, U.; SERCHELI, R.; VARGAS, R. M. Transesterification of vegetable oils: a review. Journal of the Brazilian Chemical Society, 1998, 9, 199-210.

Sidemar Presotto Nunes. Departamento de Estudos Sócio-econômicos Rurais. Produção e consumo de óleos vegetais no Brasil. 2007. Disponível em: $<$ http://www.deser.org.br/documentos/doc/Produção e consumo de óleos vegetais.pdf >. Acesso em: 05 set. 2015 .

SILVA, Tamyris Borges. Contaminação microbiológica de diesel comercial no Distrito Federal. 2015. xiv, 68 f., il. Dissertação (Mestrado em Tecnologias Químicas e Biológicas)—Universidade de Brasília, Brasília, 2015.

SUAREZ, Paulo A.z.; ABREU, Frederique R.. O Biodiesel no Brasil. Senatus, Brasília, v. 4, n. 1, p.49-52, nov. 2005. 
SUAREZ, Paulo A. Z;; MENEGHETTI, Simoni M. Plentz; WOLF, Carlos R.. Transformação de Triglicerídeos em Combustíveis, Materiais Poliméricos e Insumos Químicos: Algumas Aplicações catálise na Oleoquímica. Quim. Nova, Brasília, v. 30, n. 3, p.667-676, 2007.

SUPPES, G. J.; TSHUNG, T. T.; MASON, M. H.; HEPPERT, J. A. Performance Advantages of Cetane Improvers Produced From Soybean Oil. Proceedings of the Fourth Biomass Conference of the Americas. DOE Publication, Oakland, CA, 1999.

SUPPES, Galen J.; DASARI, MohanprasadA.. Synthesis and Evaluation of Alkyl Nitrates from Triglycerides as Cetane Improvers. Industrial \& Engineering Chemistry Research, [s.1.], v. 42, n. 21, p.5042-5053, out. 2003. American ChemicalSociety (ACS). http://dx.doi.org/10.1021/ie030015g.

SZKLO, A. S.; ULLER, V. C. Fundamentos do refino de petróleo: tecnologia e economia. $3^{\mathrm{a}}$ ed. rev. e ampl. Rio de Janeiro: Interciência, 2008.

VON HOLLEBEN, Maria Luiza Ambros; SCHUCH, Cristina Maria. Activating agents of the hydrogen peroxide in the epoxidation of unfunctionalized alkenes. QuÍmica Nova, Porto Alegre, v. 1, n. 20, p.58-75, jun. 1996.

VALENÇA, Ubirajara da Silva. UM POUCO DA HISTÓRIA DOS EXPLOSIVOS ATRAVÉS DE SEUS DESCOBRIDORES.Desenvolvimento e Tecnologia, Brasil, v. 18, n. 1, p.1-62, jan. 2001.

ZIMMER, A.R.; CAZAROLLI, J.; TEIXEIRA, R. M.; VISCARDI, S.L.C. ; CAVALCANTI, E. S. H.; GERBASE,A.;FERRÃO,M.F; PIATNICK, C.M.S.; BENTO, F.M. Monitoring of effectivity of biocides during storage simulation of diesel (B0), biodiesel (B100) and blends (B7 AND B10). In: IASH 2011, the 12TH INTERNATIONAL CONFERENCE ON STABILITY, HANDLING AND USE OF LIQUID FUELS ,October 16-20 , 2011, Sarasota, Florida USA. 
8. ANEXOS 


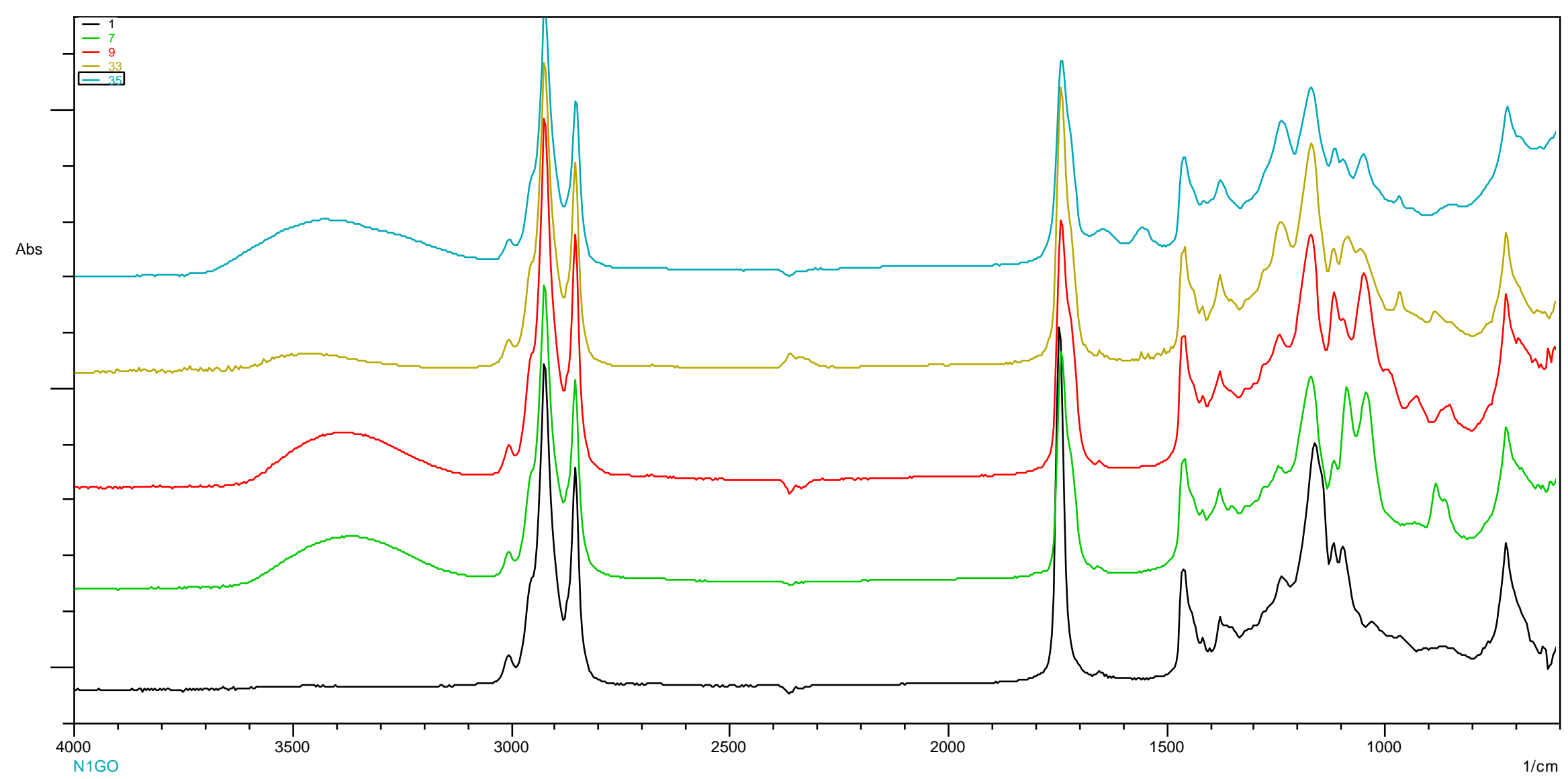

Anexo 1: Espectros de Infra-vermeho de alguns derivados do azeite de oliva, são eles os compostos: 1, 7, 9, 33 e 35. 


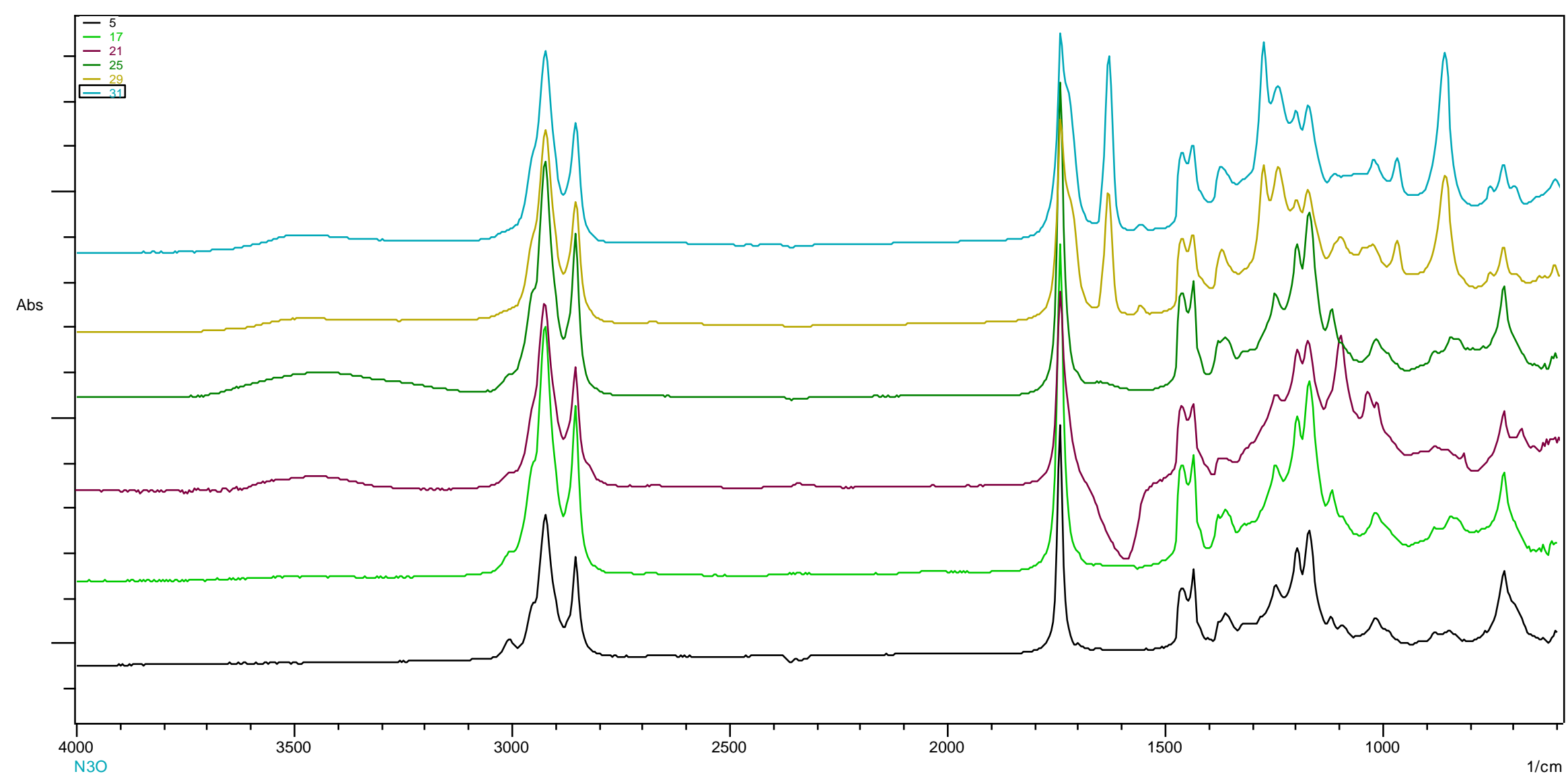

Anexo 2: Espectros de Infra-vermeho de alguns derivados do azeite de oliva, são eles os compostos: 5, 17, 21, 25, 29 e 31. FONTE: Próprio autor. 


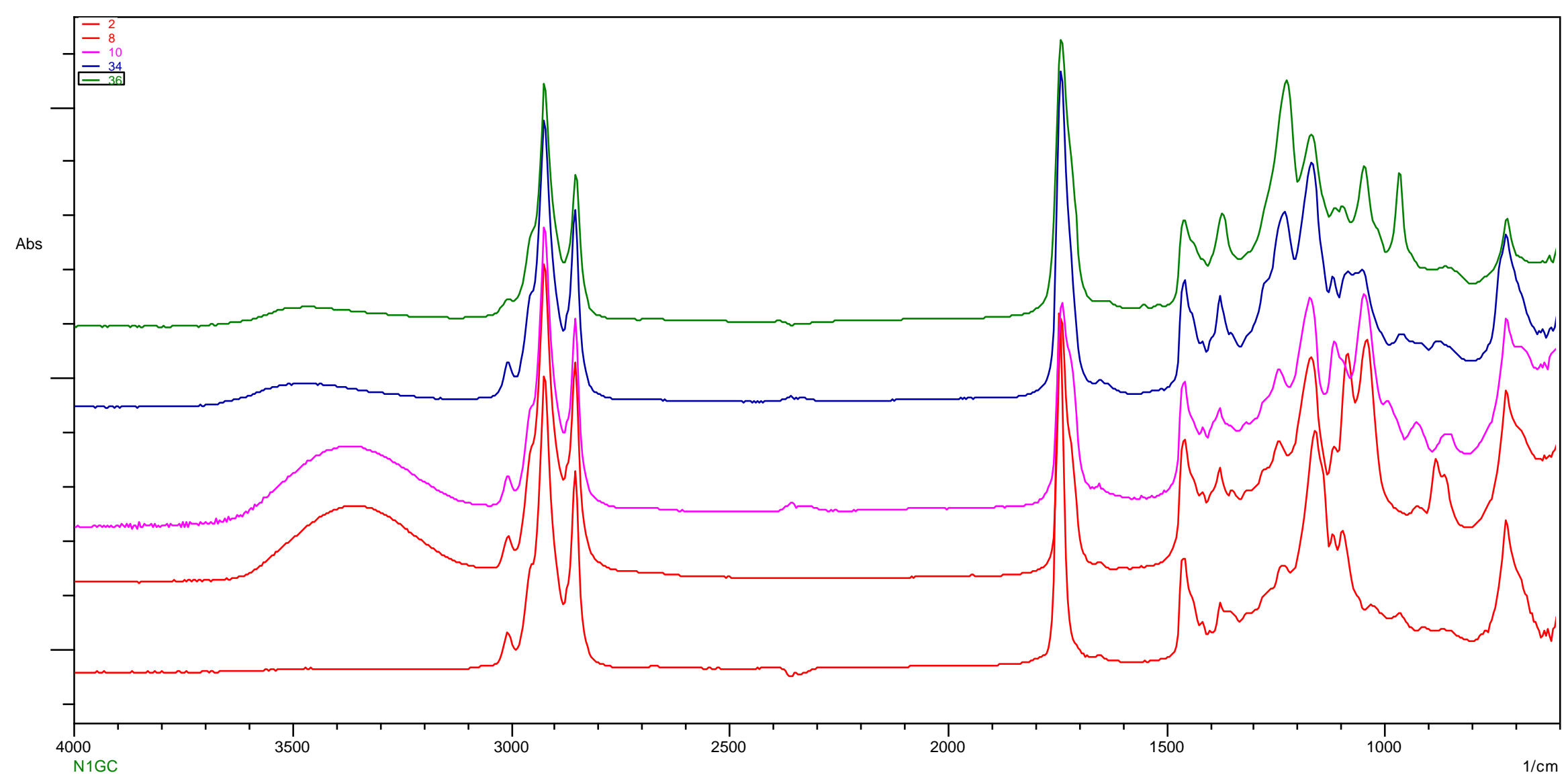

Anexo 3: Espectros de Infra-vermeho de alguns derivados do óleo de canola, são eles os compostos: 2, 8, 10, 34 e 36. FONTE: Próprio autor. 


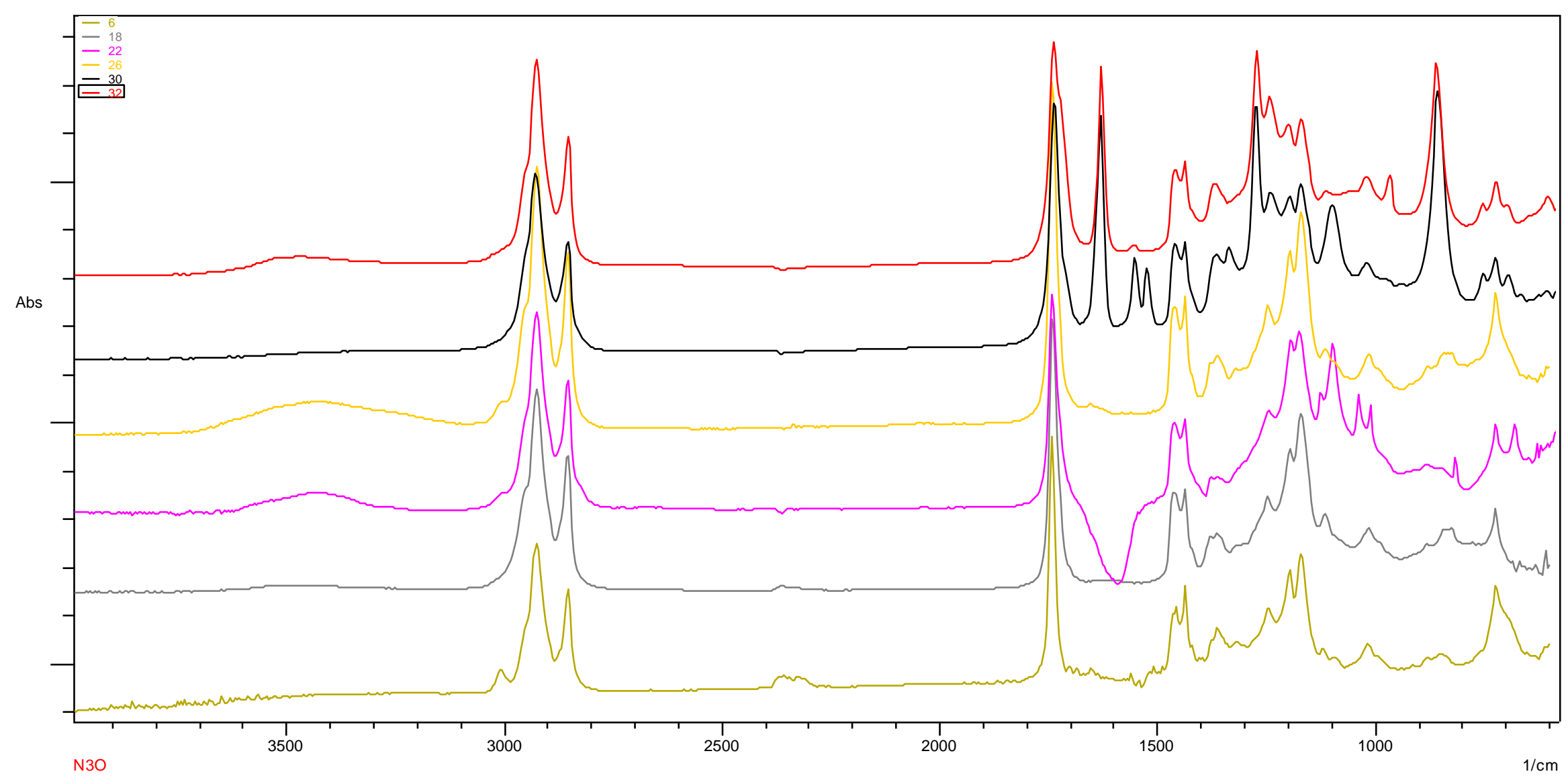

Anexo 4: Espectros de Infra-vermeho de alguns derivados do óleo de canola, são eles os compostos: 6, 18, 22, 26, 30 e 32. FONTE: Próprio autor. 


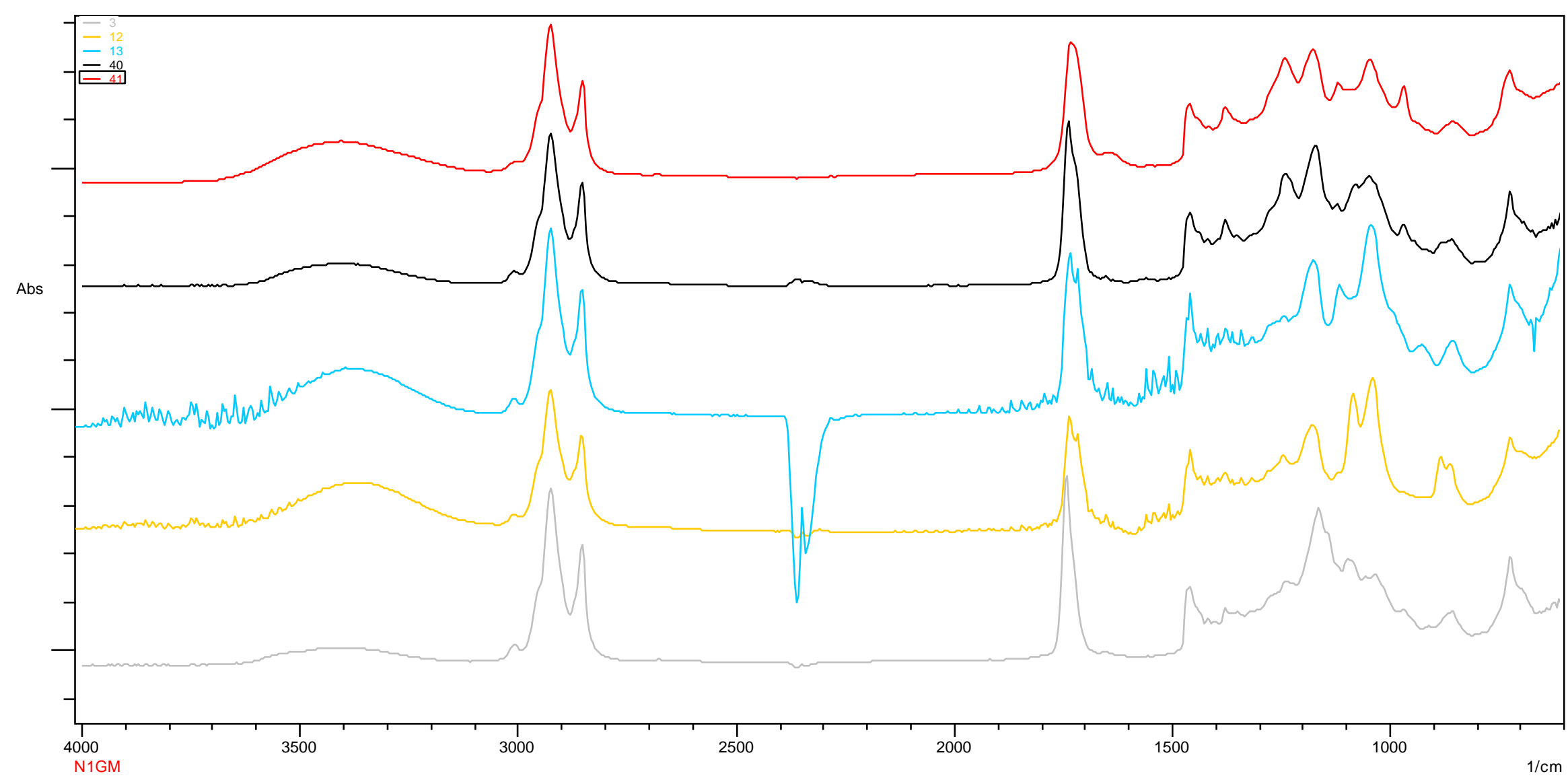

Anexo 5: Espectros de Infra-vermeho de alguns derivados do óleo de mamona, são eles os compostos: 3, 12, 13, 40 e 41. FONTE: Próprio autor. 


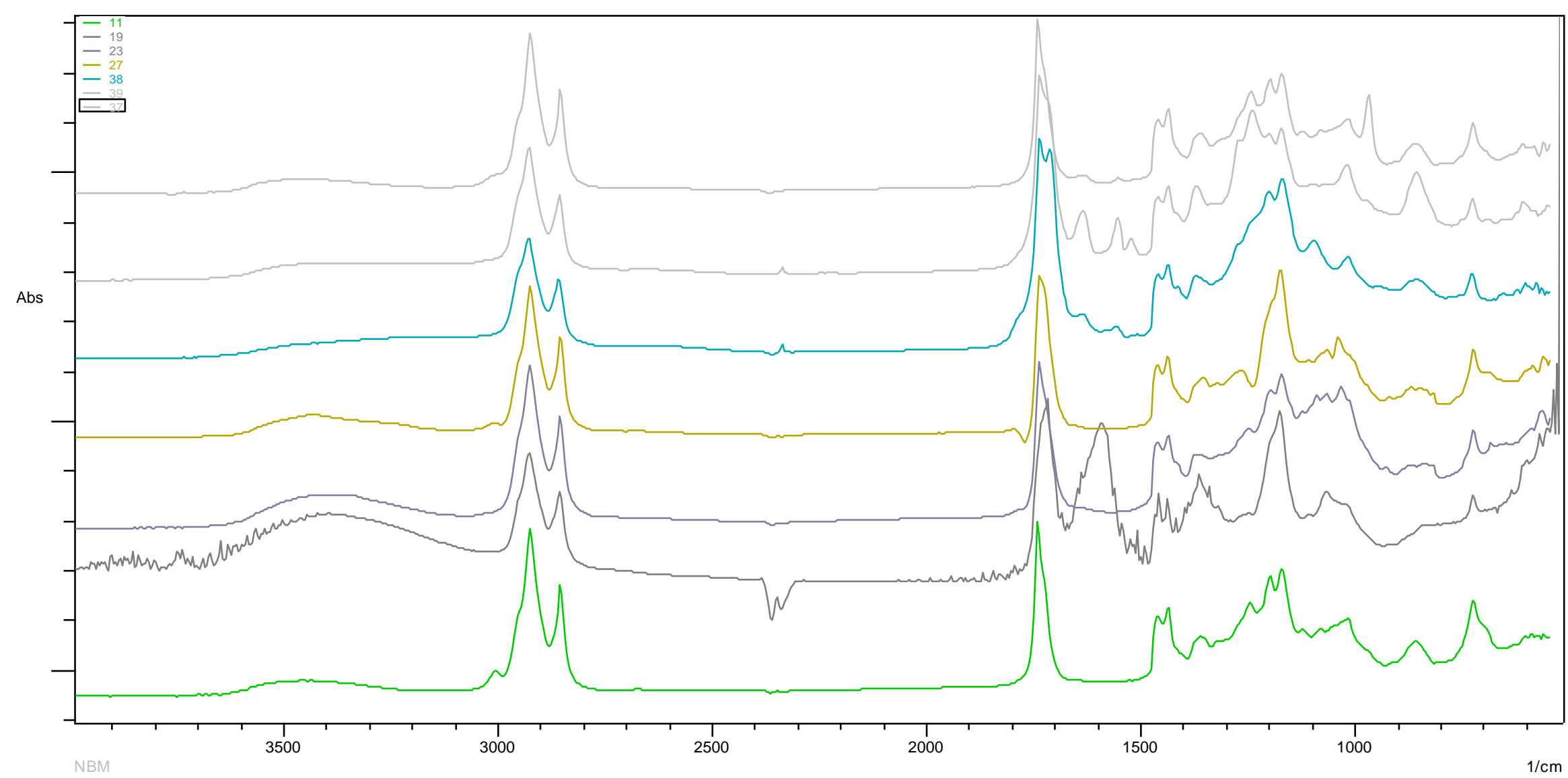

Anexo 6: Espectros de Infra-vermeho de alguns derivados do óleo de mamona, são eles os compostos: 11, 19, 23, 27, 38,37 e 39 . FONTE: Próprio autor. 


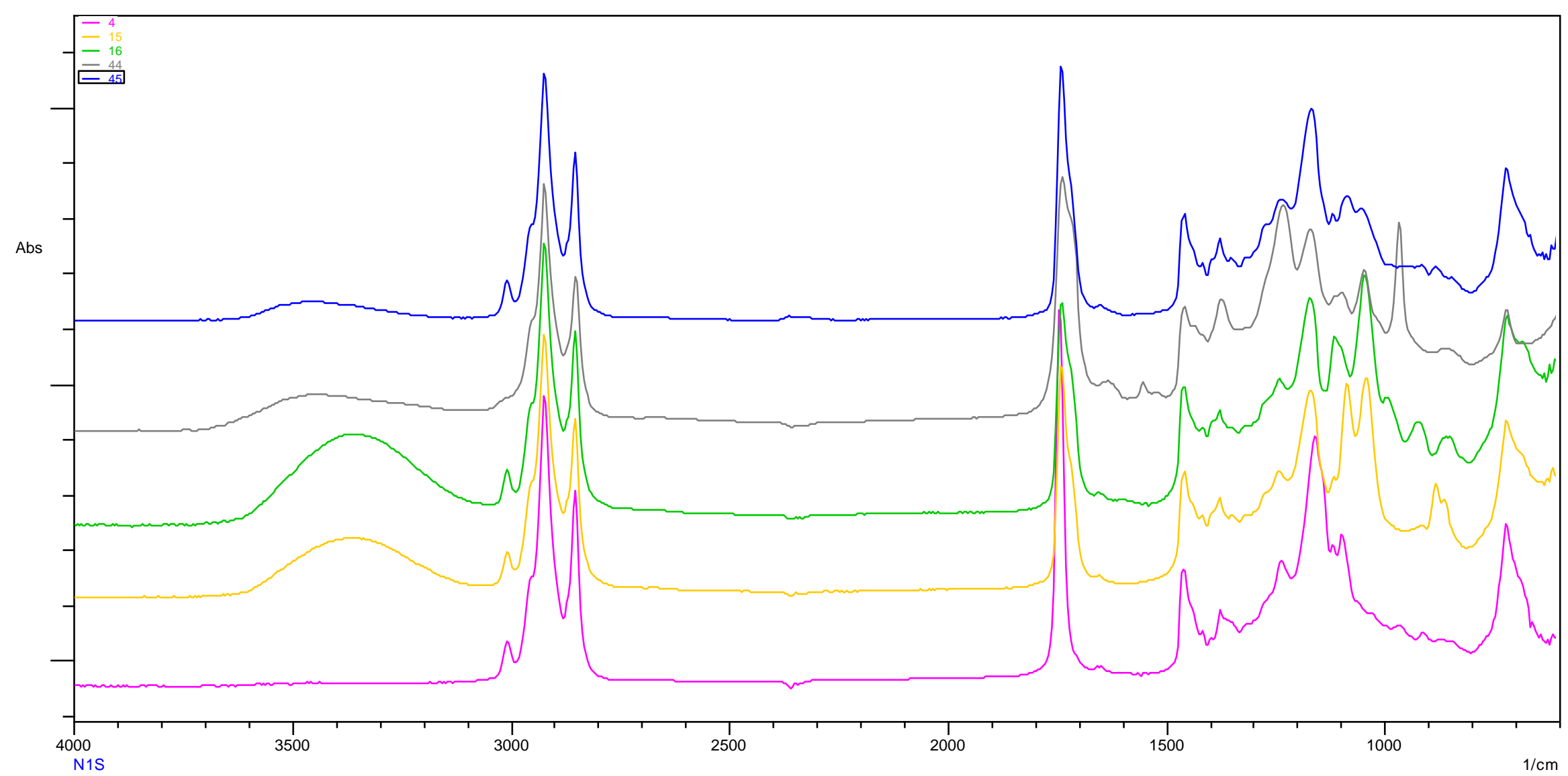

Anexo 7: Espectros de Infra-vermeho de alguns derivados do óleo de soja, são eles os compostos: 4, 15, 16, 44 e 45. FONTE: Próprio autor. 


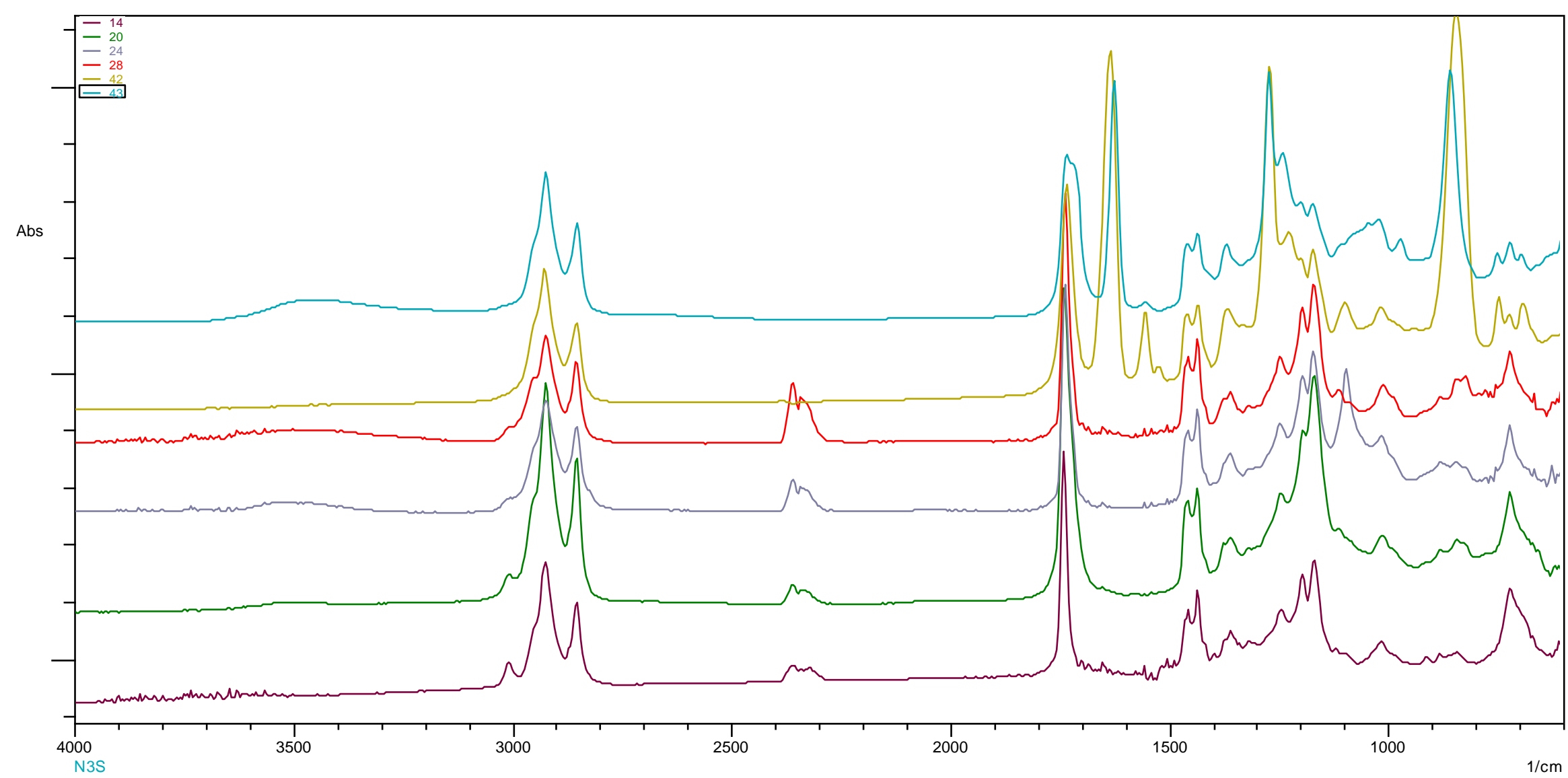

Anexo 8: Espectros de Infra-vermeho de alguns derivados do óleo de soja, são eles os compostos: 14, 20, 24, 28, 42 e 43. FONTE: Próprio autor. 


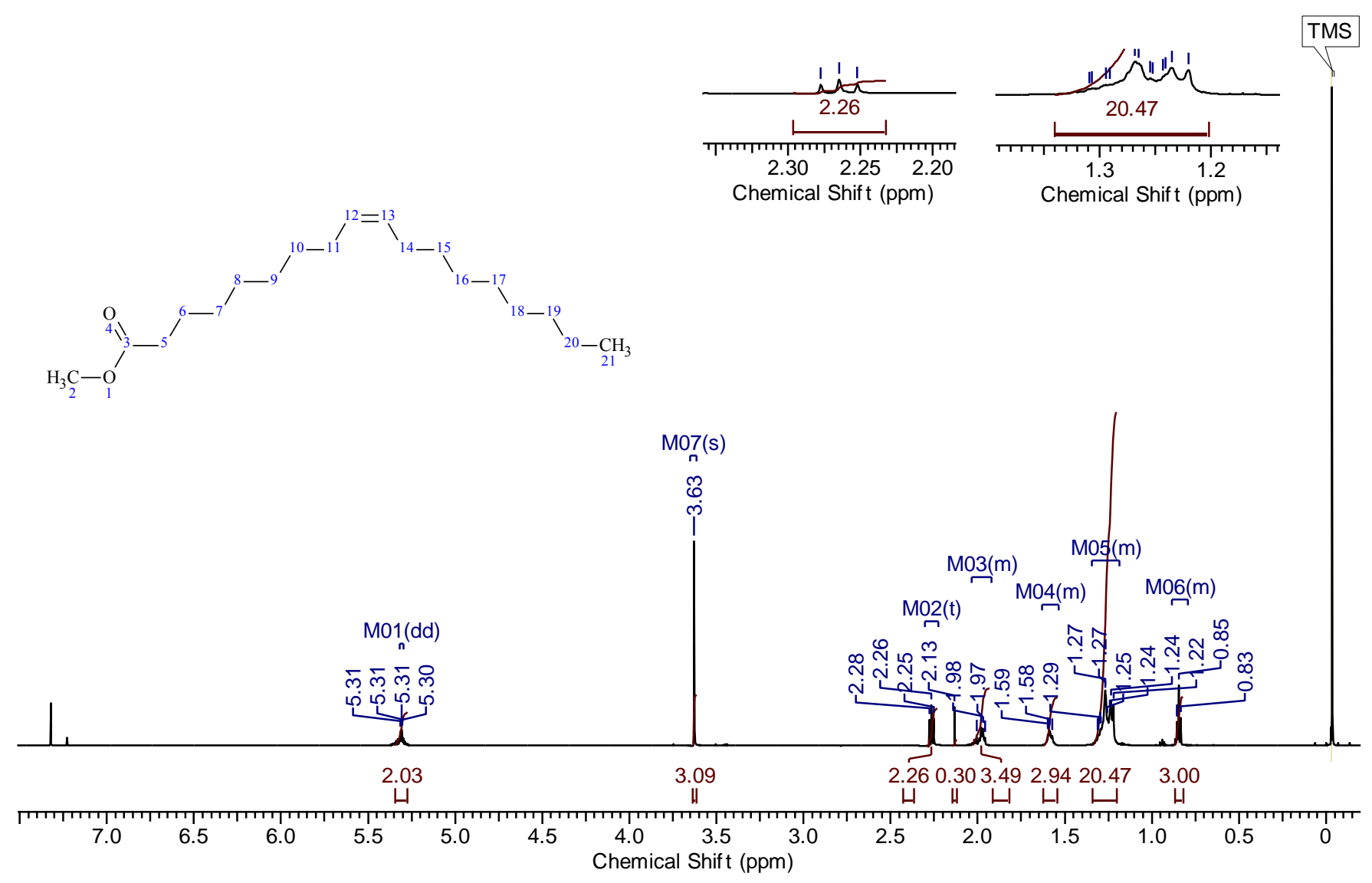

Anexo 9: Espectro de ressonância magnética nuclear de hidrogênio $\left({ }^{1} \mathrm{H}\right.$ RMN) do composto número 6. FONTE: Próprio autor. 


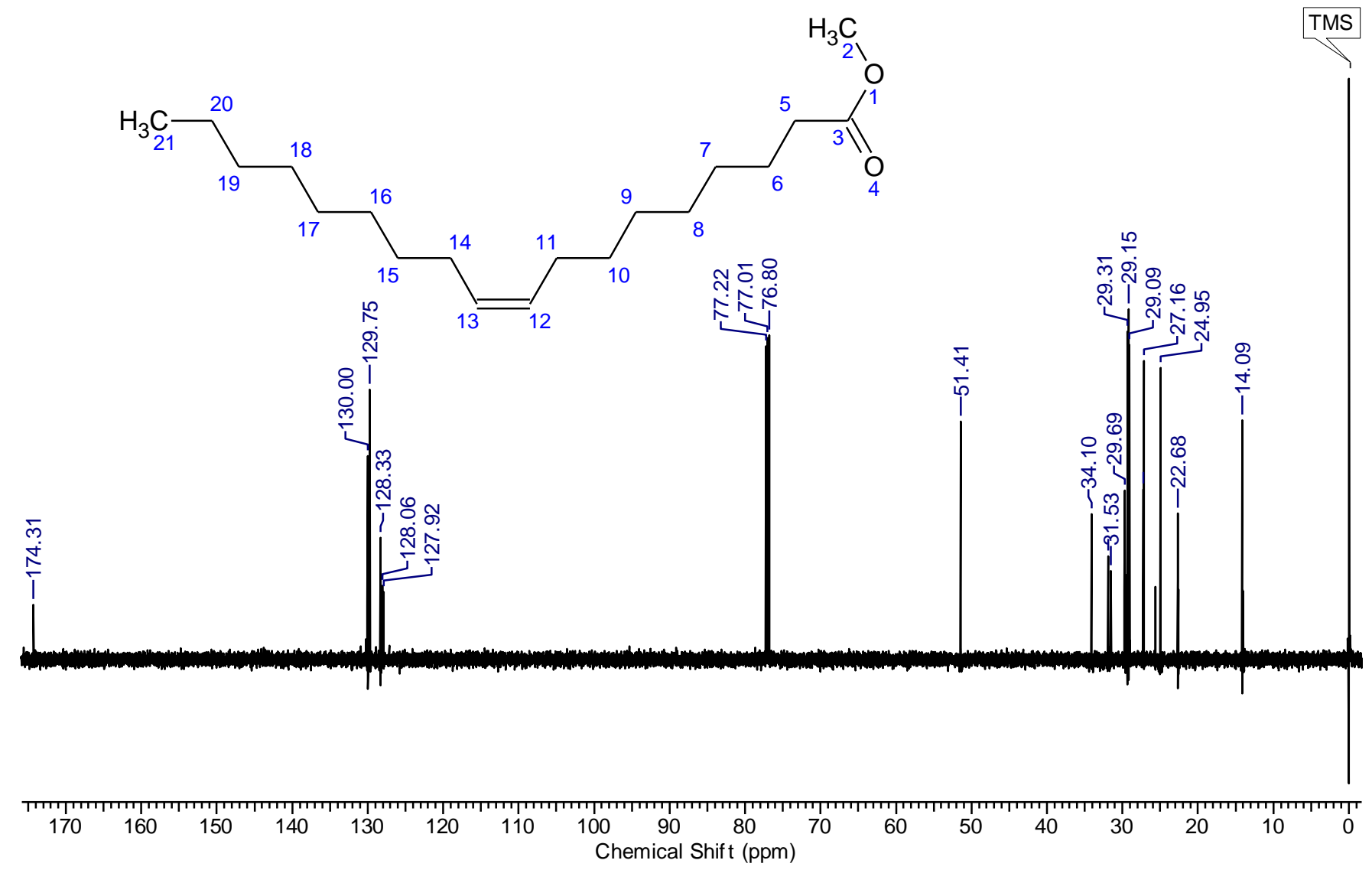

Anexo 10: Espectro de ressonância magnética nuclear de carbono $\left({ }^{13} \mathrm{C}\right.$ RMN $)$ do composto número 6. FONTE: Próprio autor. 


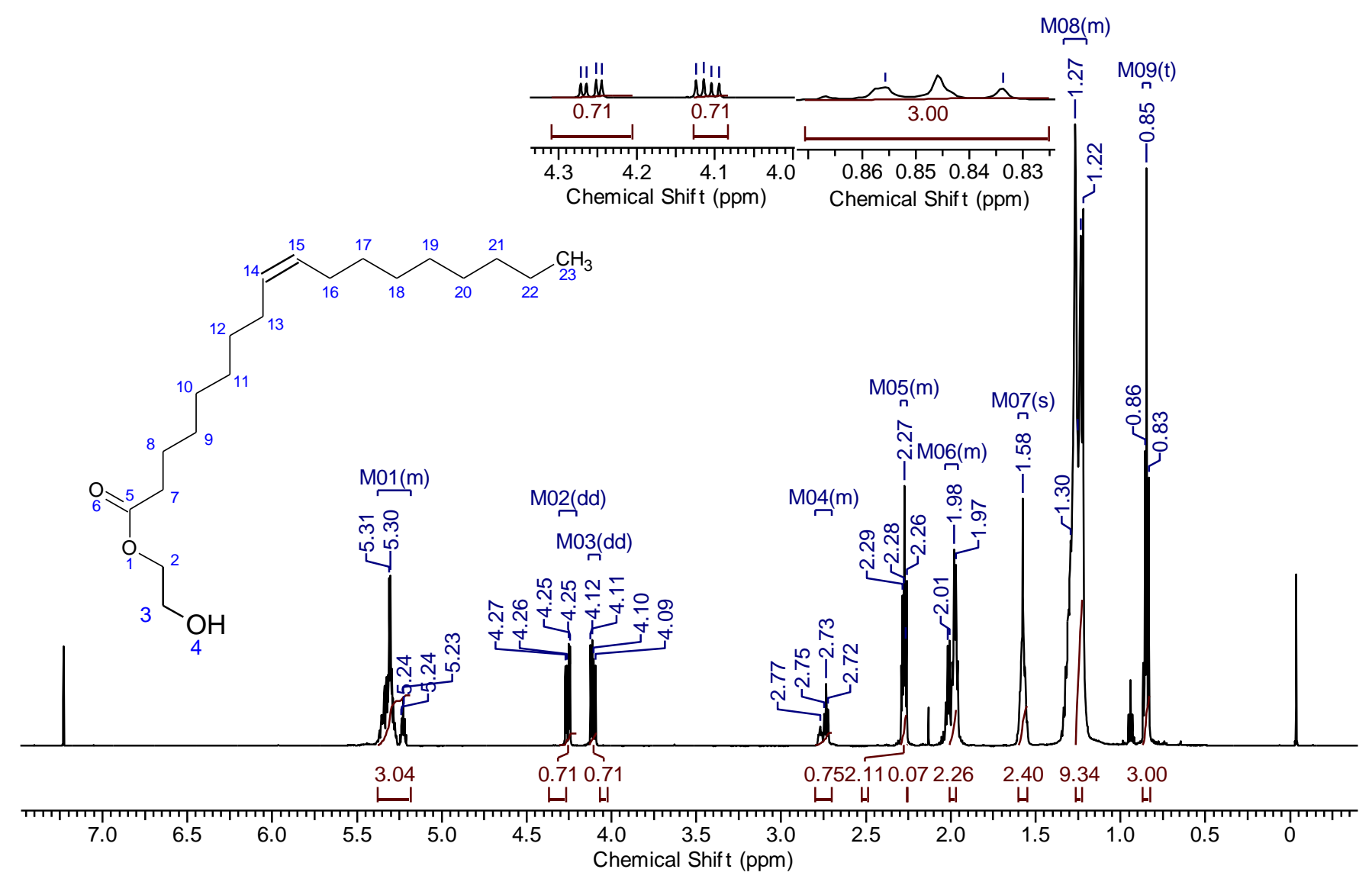

Anexo 11: Espectro de ressonância magnética nuclear de hidrogênio $\left({ }^{1} \mathrm{H}\right.$ RMN) do composto número 7. FONTE: Próprio autor. 


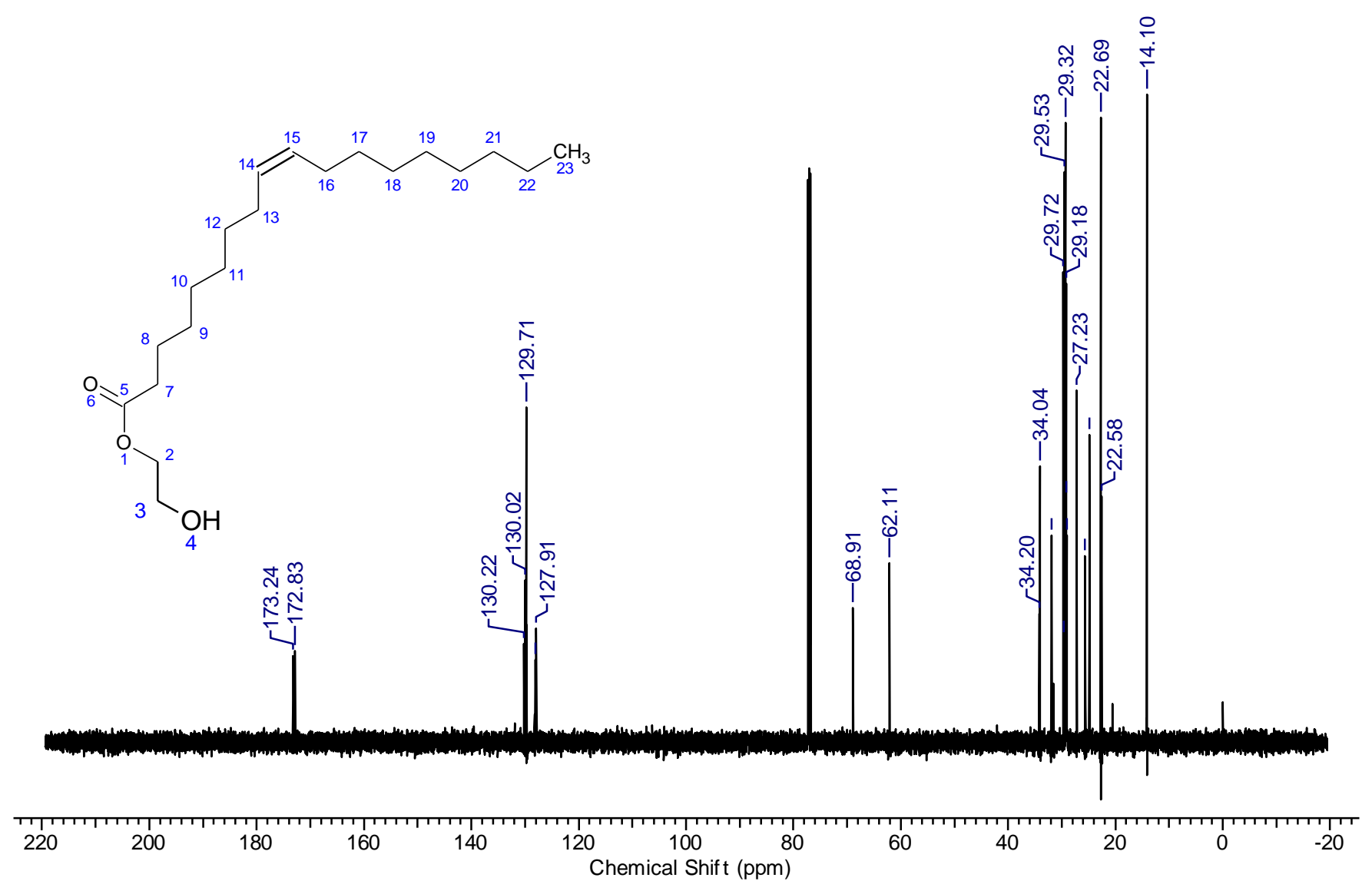

Anexo 12: Espectro de ressonância magnética nuclear de carbono $\left({ }^{13} \mathrm{C}\right.$ RMN $)$ do composto número 7. FONTE: Próprio autor. 


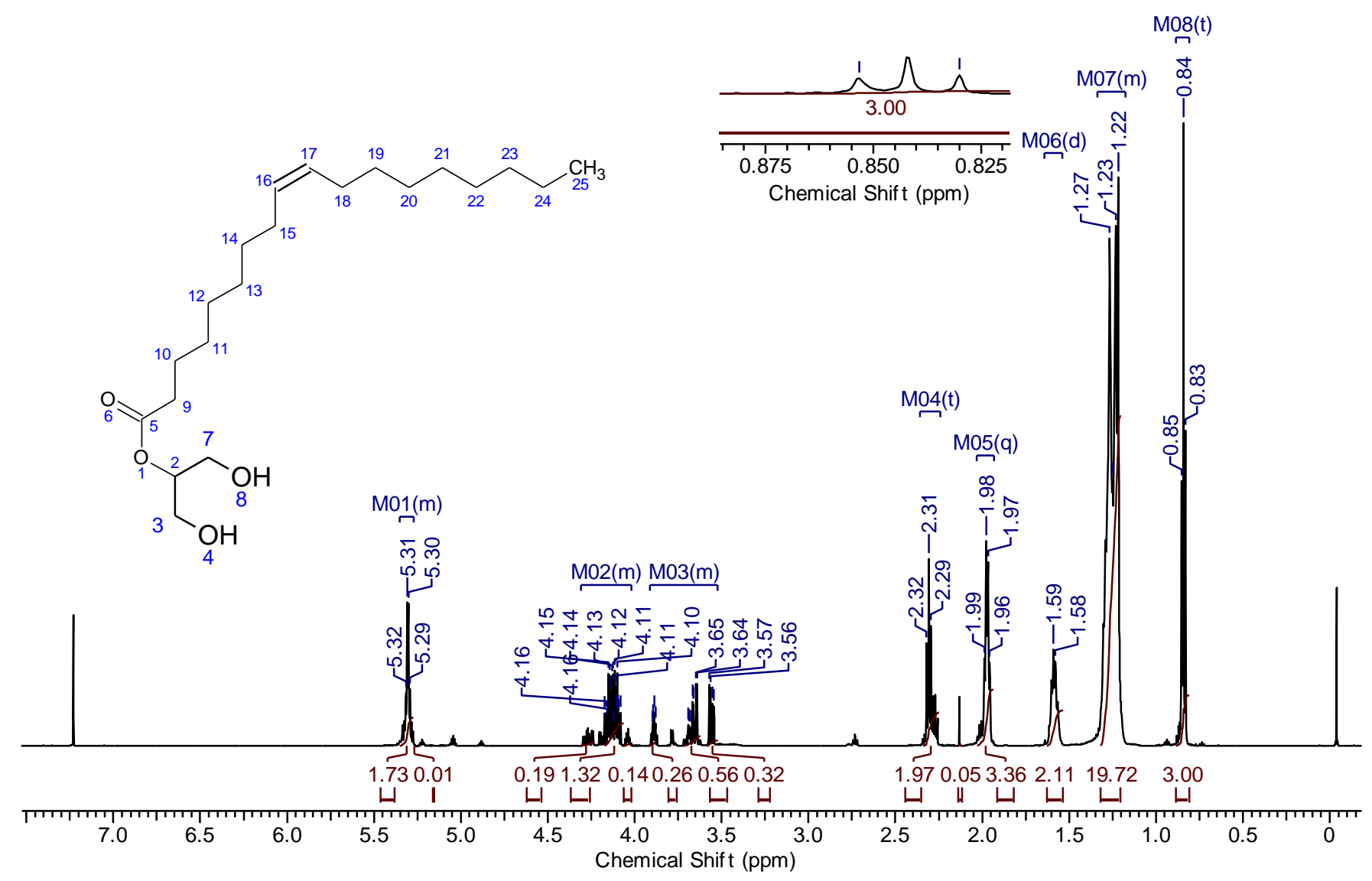

Anexo 13: Espectro de ressonância magnética nuclear de hidrogênio ( ${ }^{1} \mathrm{H}$ RMN) do composto número 9. FONTE: Próprio autor. 


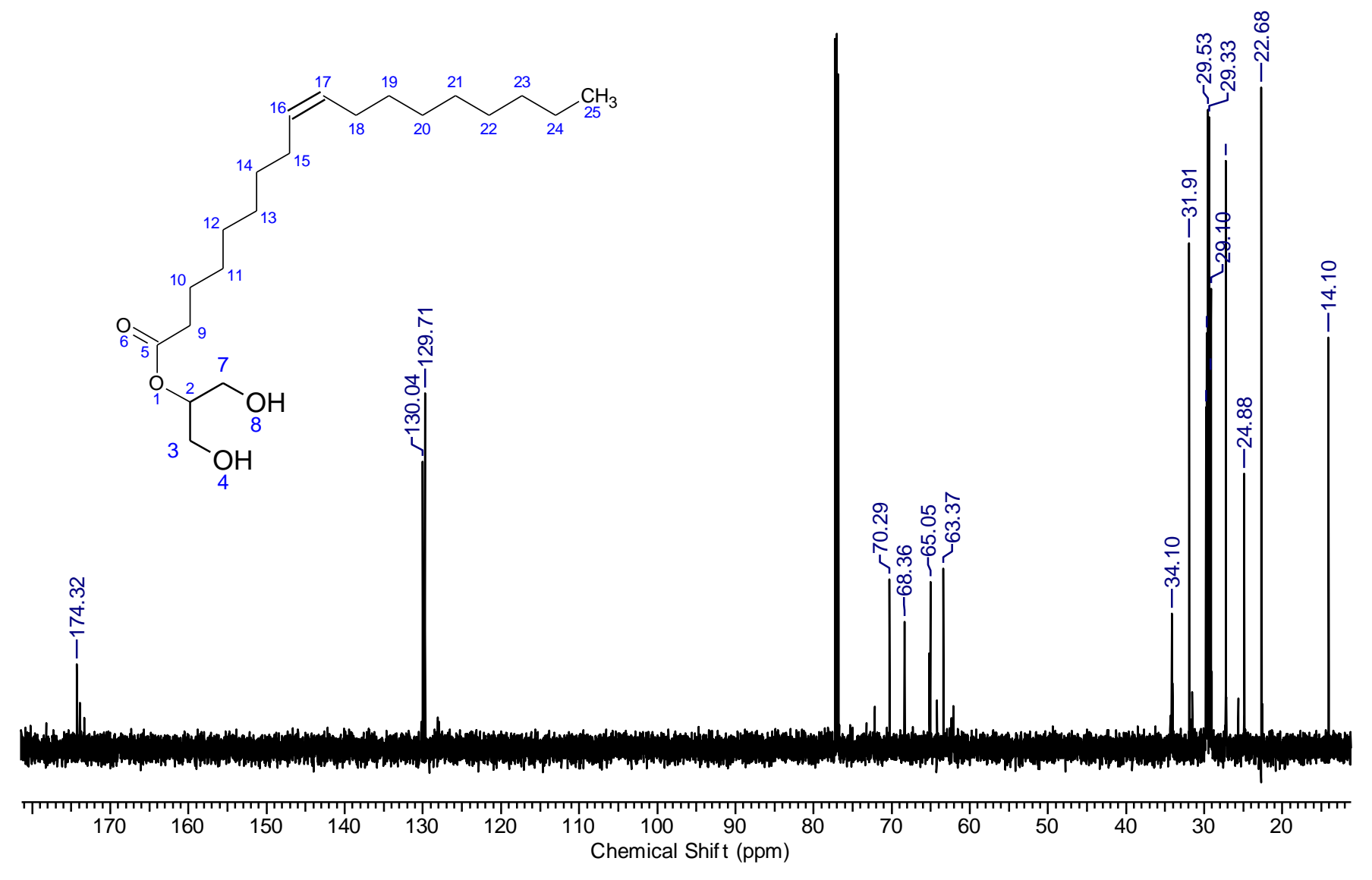

Anexo 14: Espectro de ressonância magnética nuclear de carbono $\left({ }^{13} \mathrm{C} \mathrm{RMN}\right)$ do composto número 9. FONTE: Próprio autor. 


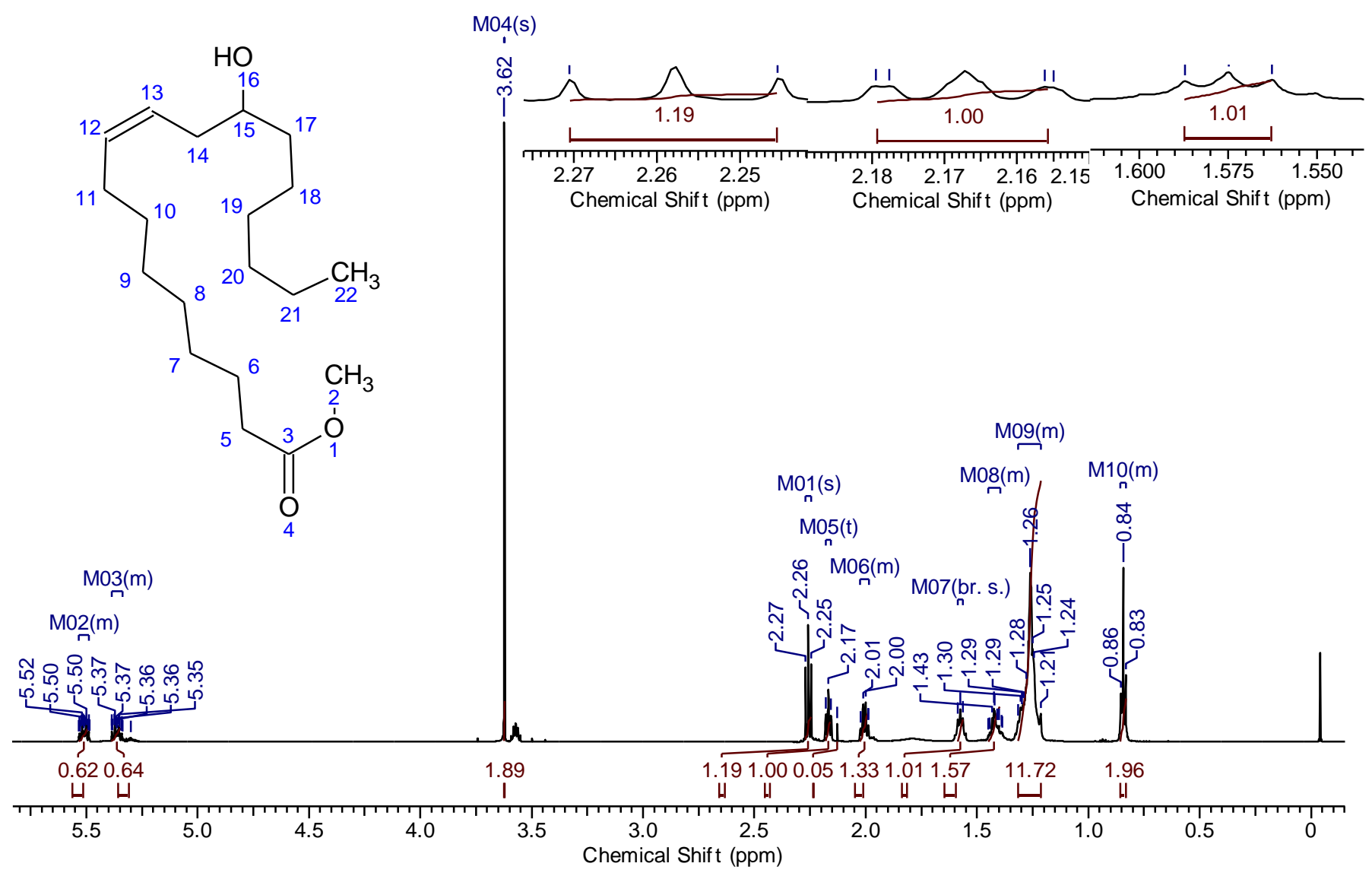

Anexo 15: Espectro de ressonância magnética nuclear de hidrogênio $\left({ }^{1} \mathrm{H}\right.$ RMN $)$ do composto número 11. FONTE: Próprio autor. 


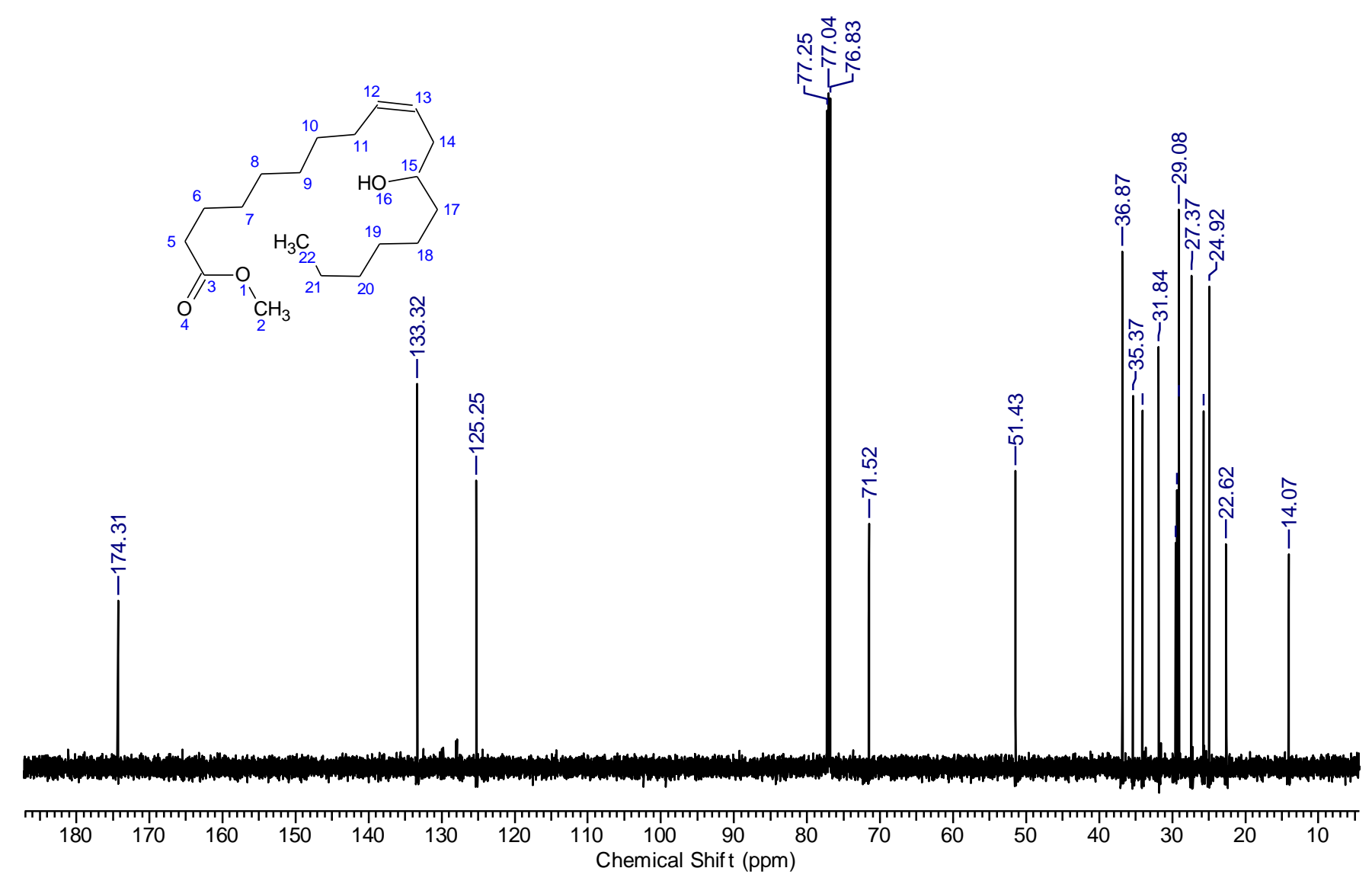

Anexo 16: Espectro de ressonância magnética nuclear de carbono $\left({ }^{13} \mathrm{C} R M N\right)$ do composto número 11. FONTE: Próprio autor. 


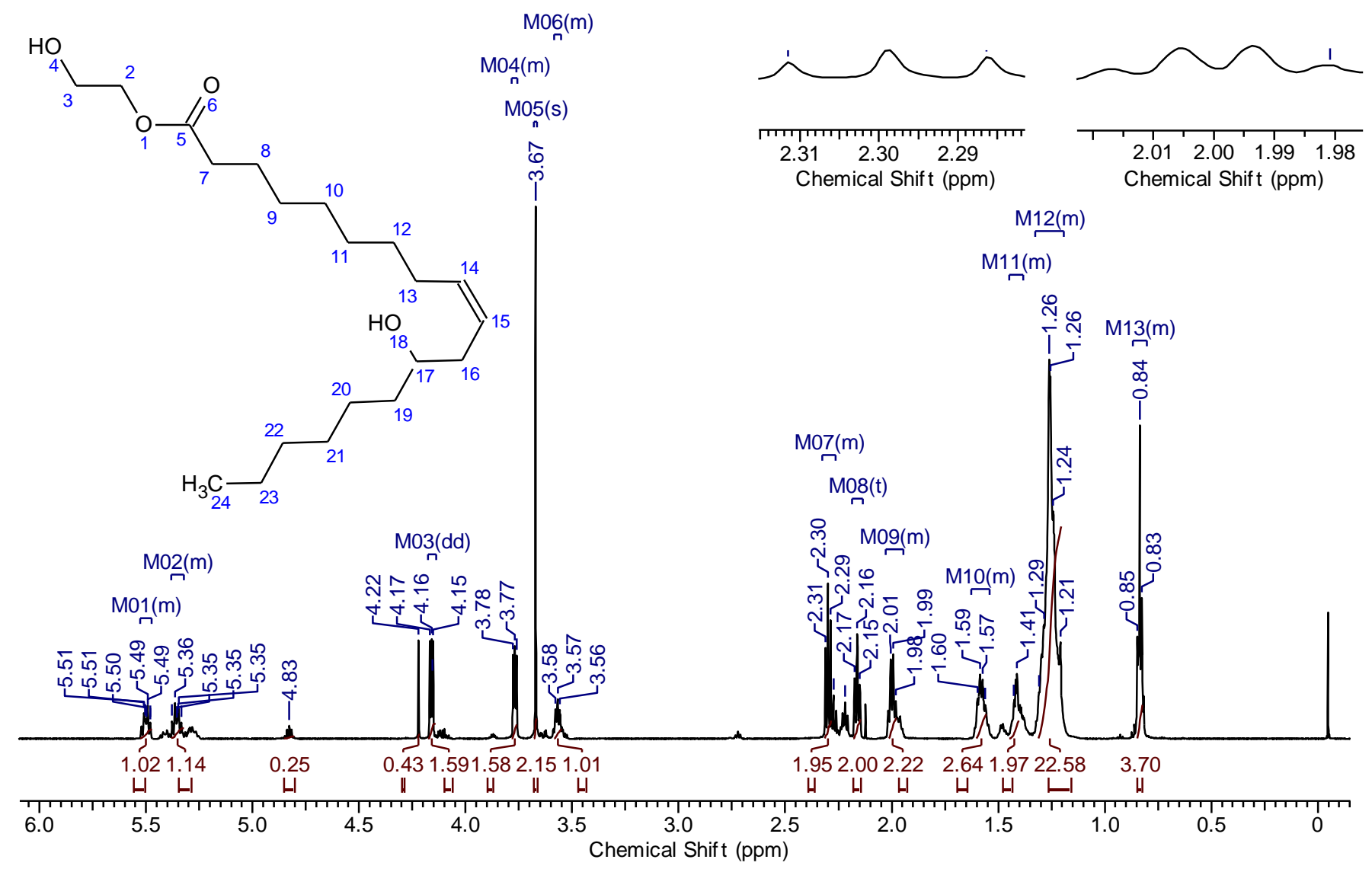

Anexo 17: Espectro de ressonância magnética nuclear de hidrogênio (1H RMN) do composto número 12. FONTE: Próprio autor. 


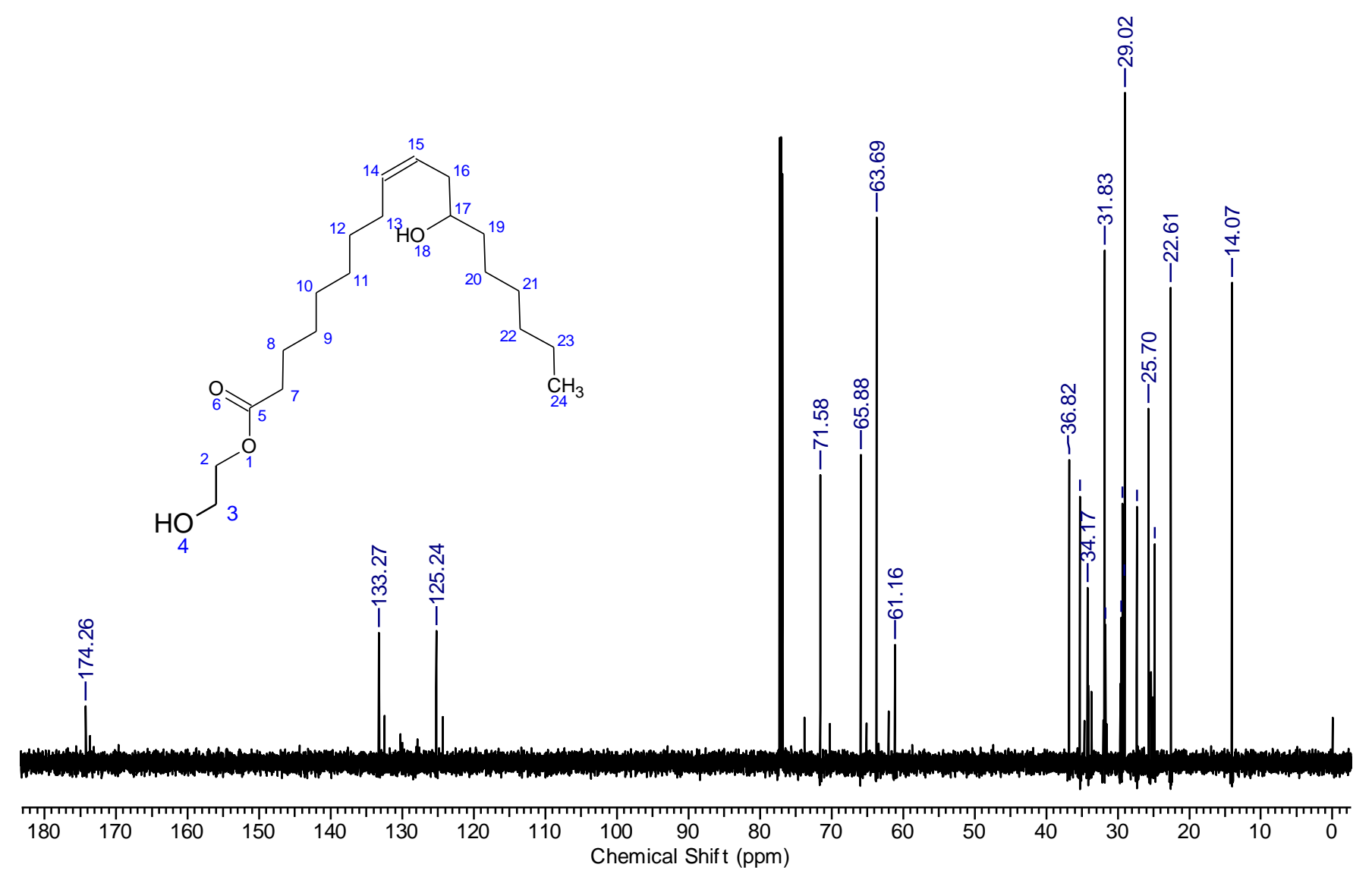

Anexo 18: Espectro de ressonância magnética nuclear de carbono $\left({ }^{13} \mathrm{C} R M N\right)$ do composto número 12. FONTE: Próprio autor. 


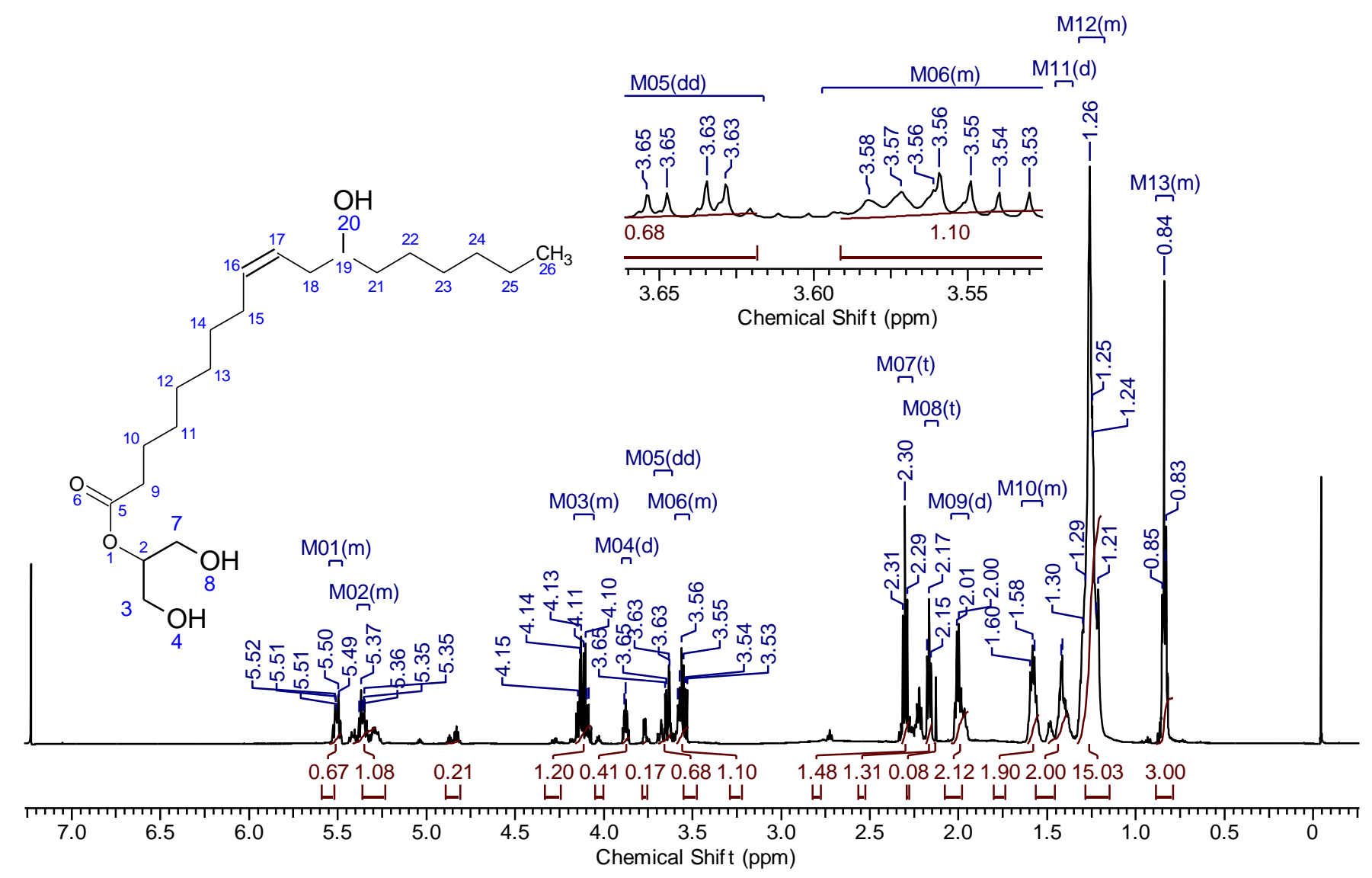

Anexo 19: Espectro de ressonância magnética nuclear de hidrogênio $\left({ }^{1} \mathrm{H}\right.$ RMN $)$ do composto número 13. FONTE: Próprio autor. 


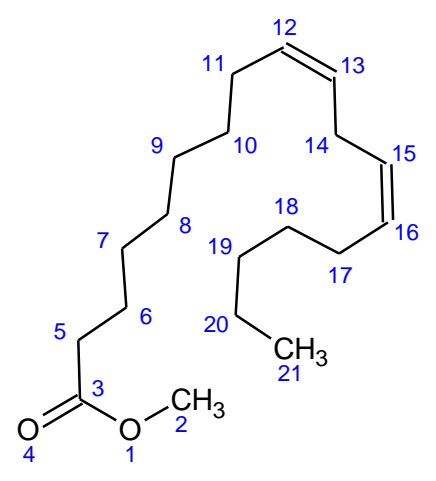

$\operatorname{M01}(m)$

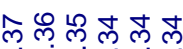

نिए

1.51

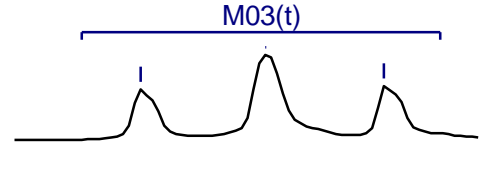

$\begin{array}{lllll}2.32 & 2.31 & 2.30 & 2.29 & 2.28\end{array}$ Chemical Shift (ppm)

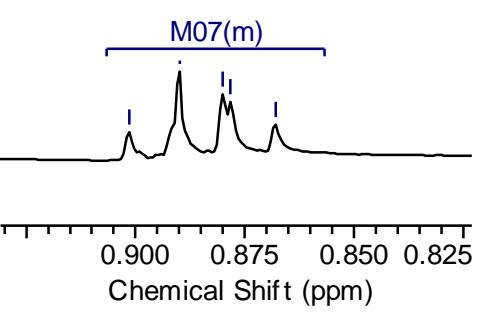

Mo2(s)

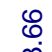

M06 (m) M07(m)

$\mathrm{M03}(\mathrm{t})$

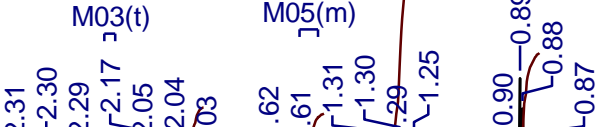

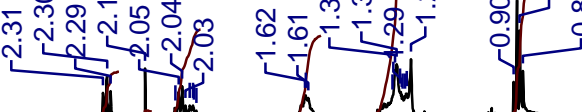

$1.390 .142 .75 \quad 2.53 \quad 10.26 \quad 4.50$

Anexo 20: Espectro de ressonância magnética nuclear de hidrogênio ( ${ }^{1} \mathrm{H}$ RMN) do composto número 14. FONTE: Próprio autor 


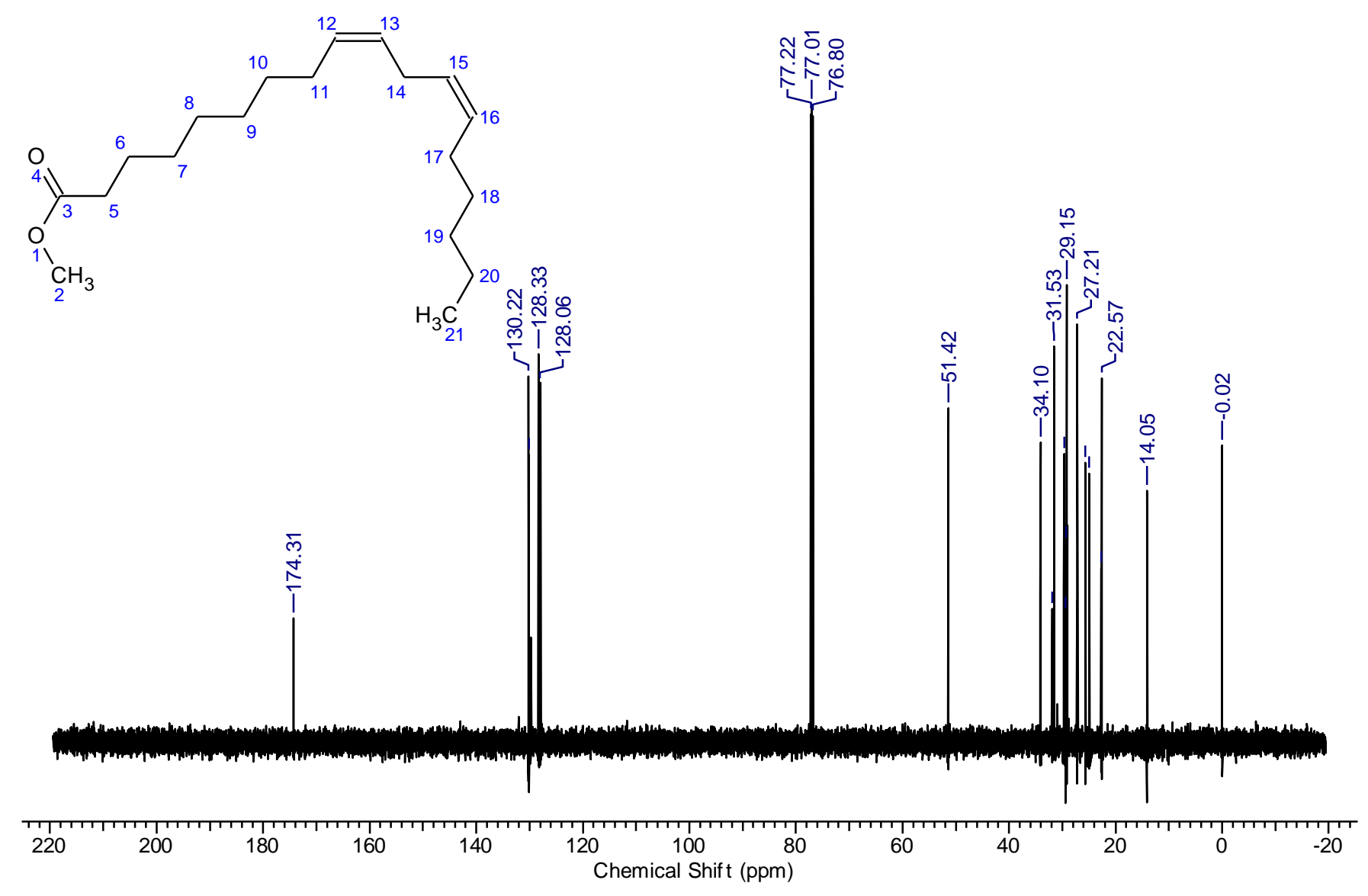

Anexo 21: Espectro de ressonância magnética nuclear de carbono $\left({ }^{13} \mathrm{C}\right.$ RMN $)$ do composto número 14. FONTE: Próprio autor. 


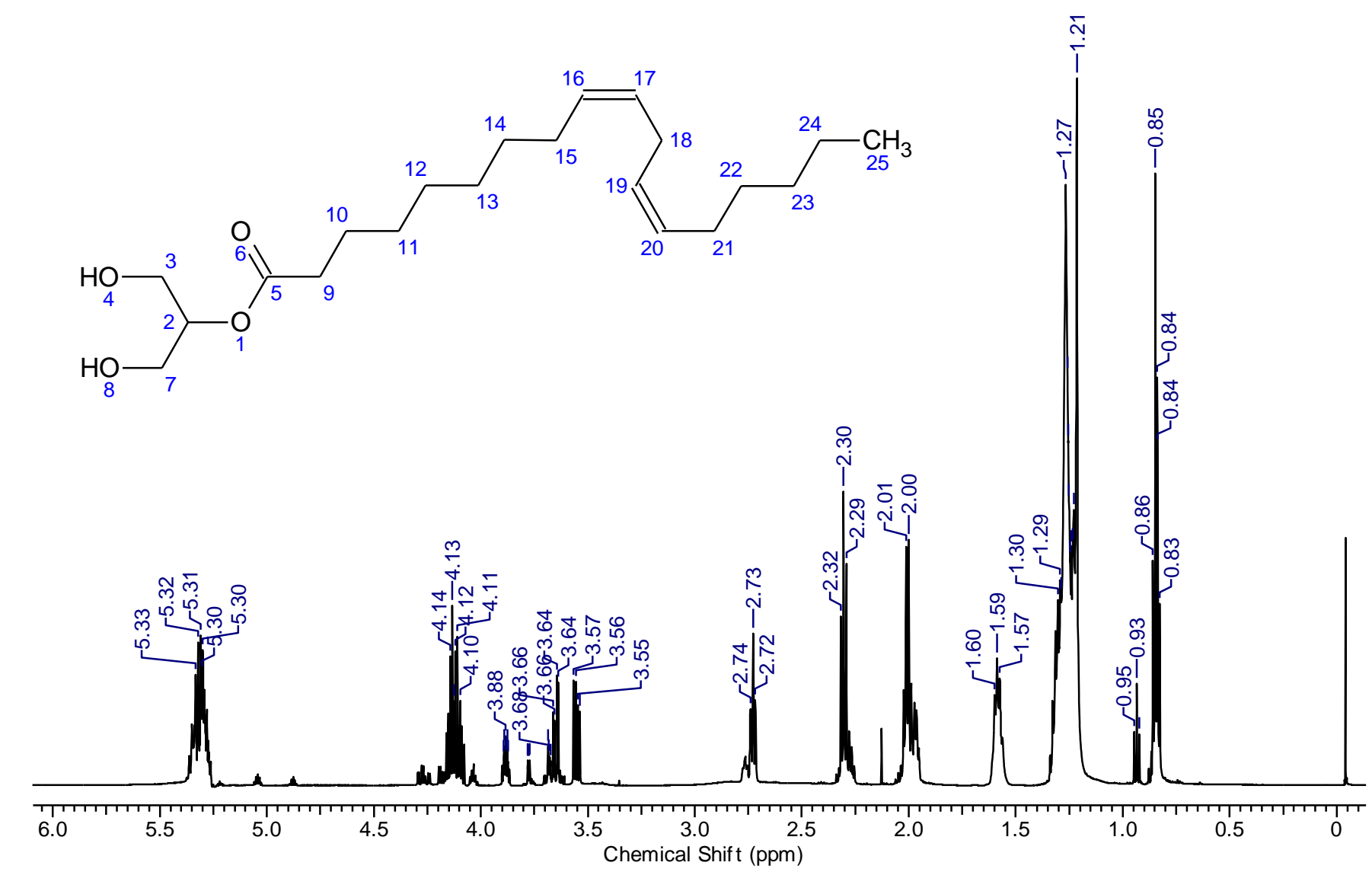

Anexo 22: Espectro de ressonância magnética nuclear de hidrogênio $\left({ }^{1} \mathrm{H}\right.$ RMN $)$ do composto número 16. FONTE: Próprio autor. 


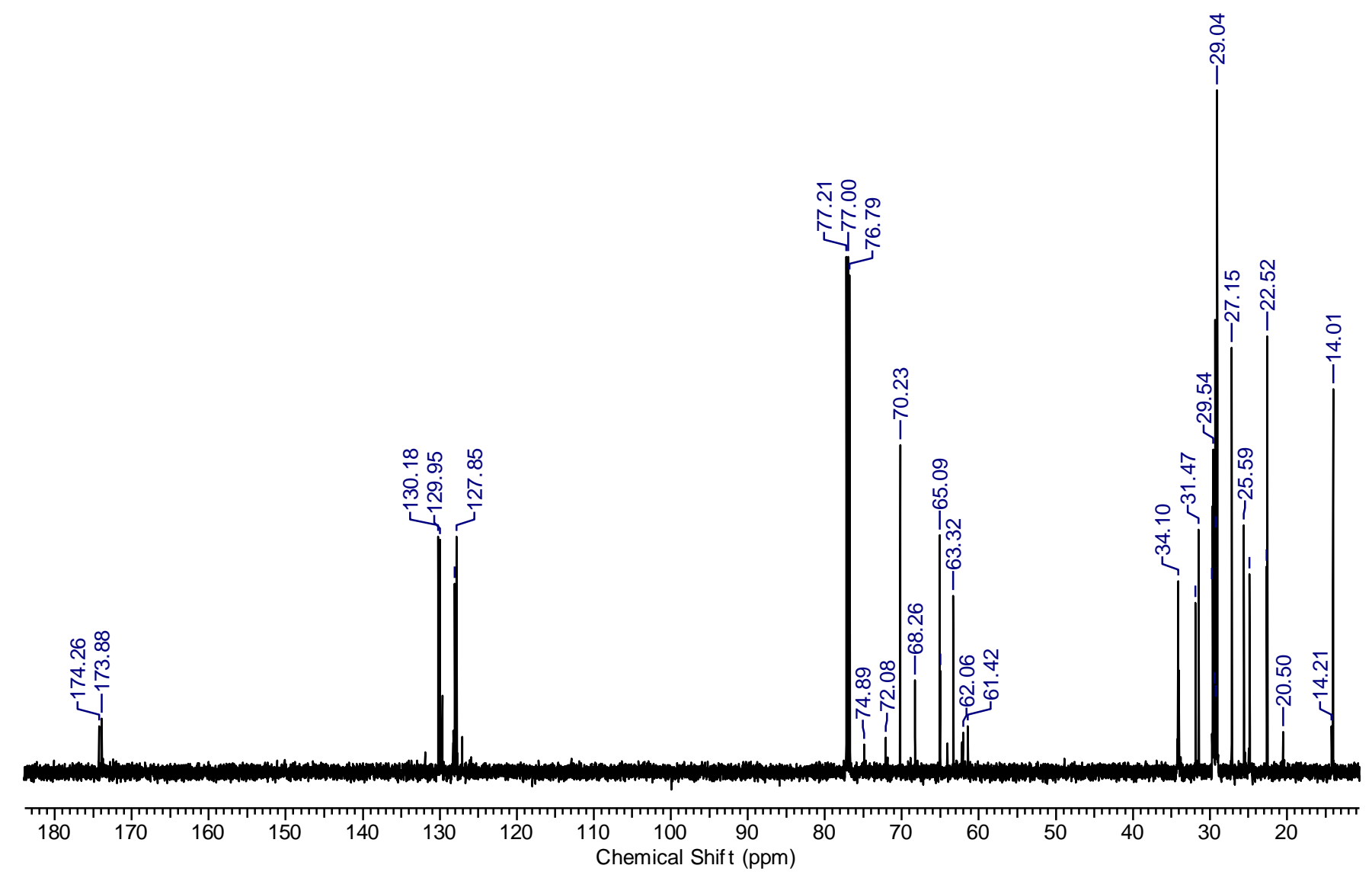

Anexo 23: Espectro de ressonância magnética nuclear de carbono $\left({ }^{13} \mathrm{C} R M N\right)$ do composto número 16. FONTE: Próprio autor. 


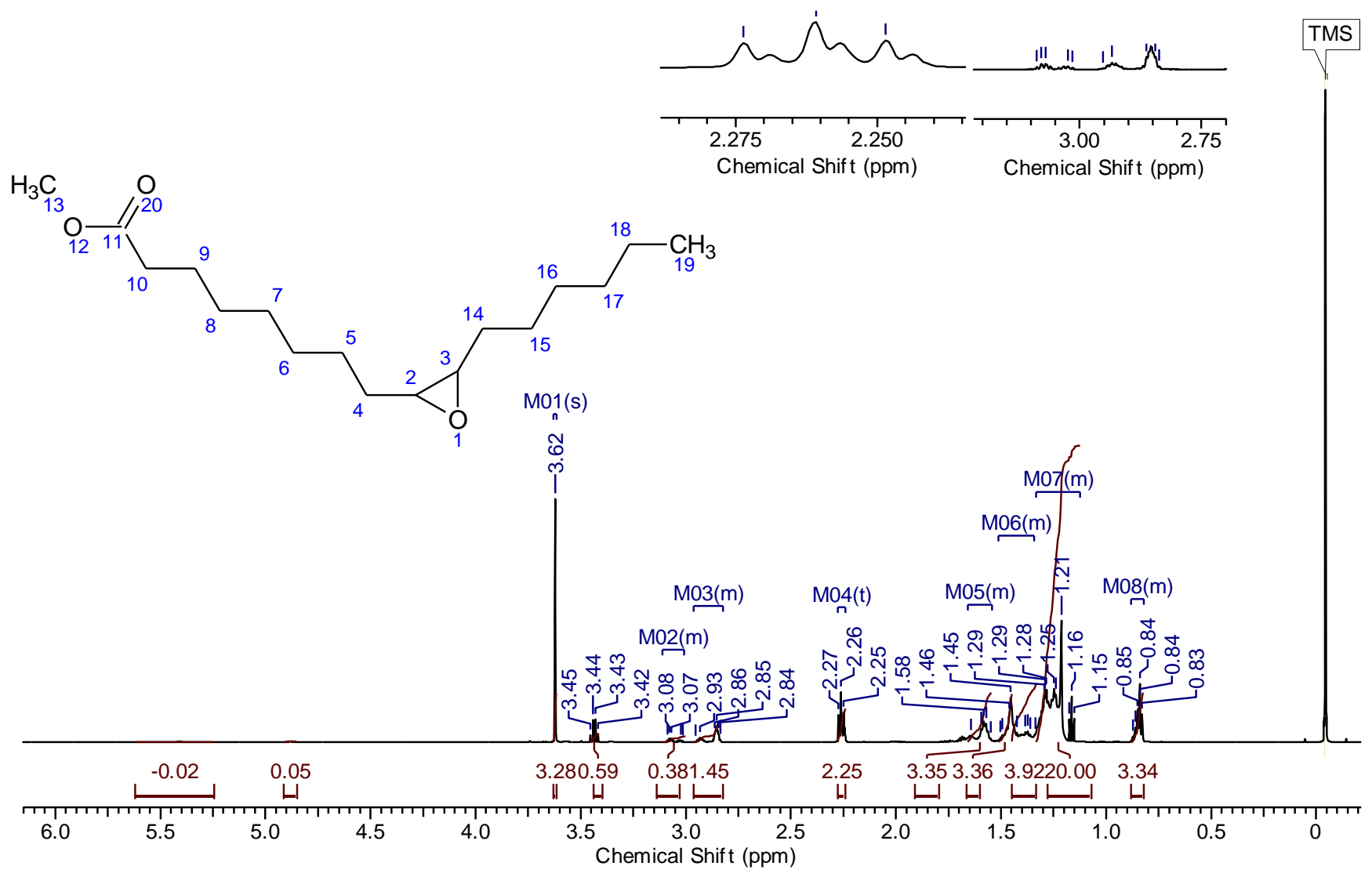

Anexo 24: Espectro de ressonância magnética nuclear de hidrogênio $\left({ }^{1} \mathrm{H}\right.$ RMN $)$ do composto número 17. FONTE: Próprio autor. 


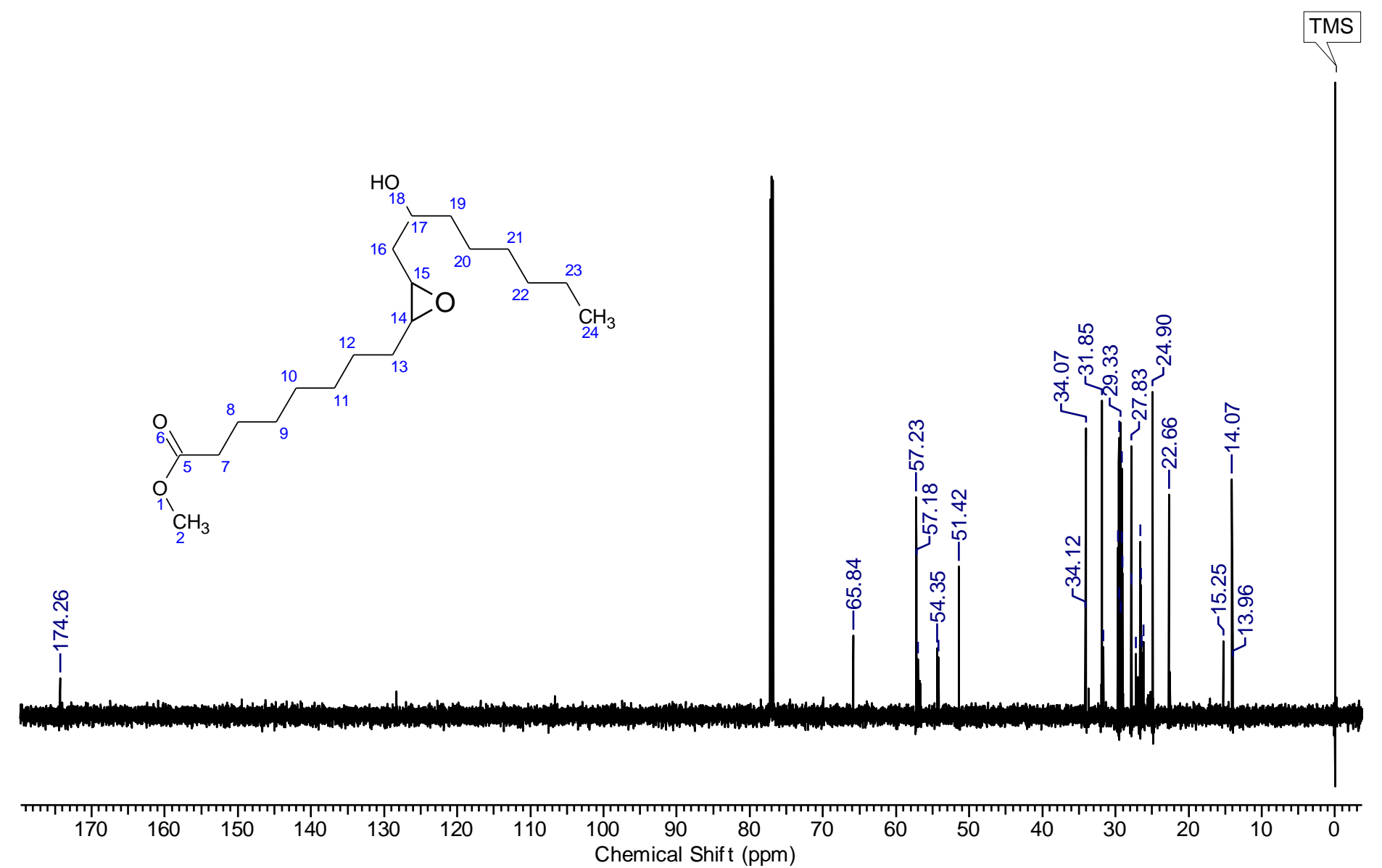

Anexo 25: Espectro de ressonância magnética nuclear de carbono $\left({ }^{13} \mathrm{C} \mathrm{RMN}\right)$ do composto número 17. FONTE: Próprio autor. 

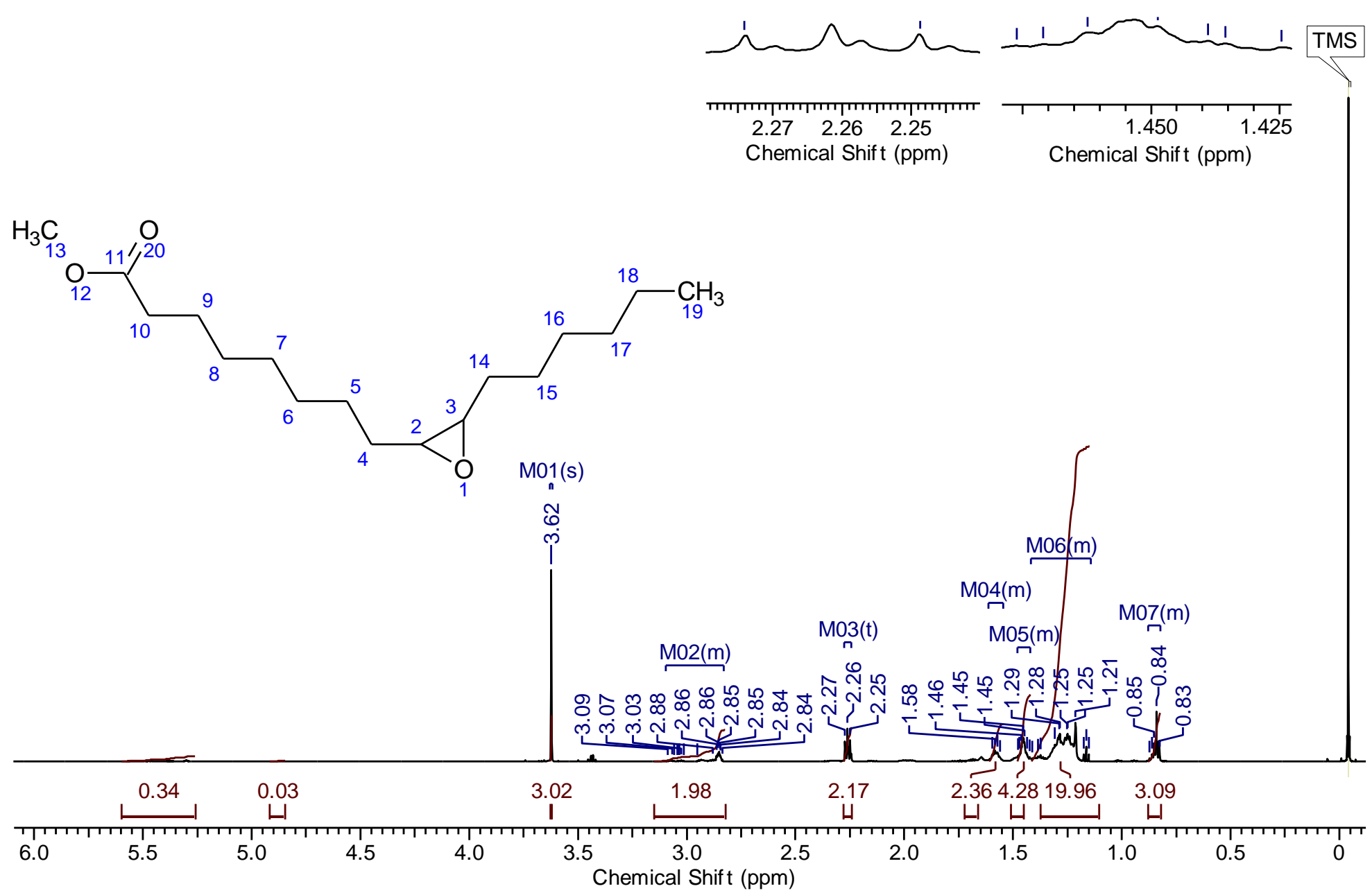

Anexo 26: Espectro de ressonância magnética nuclear de hidrogênio $\left({ }^{1} \mathrm{H}\right.$ RMN $)$ do composto número 18. FONTE: Próprio autor. 


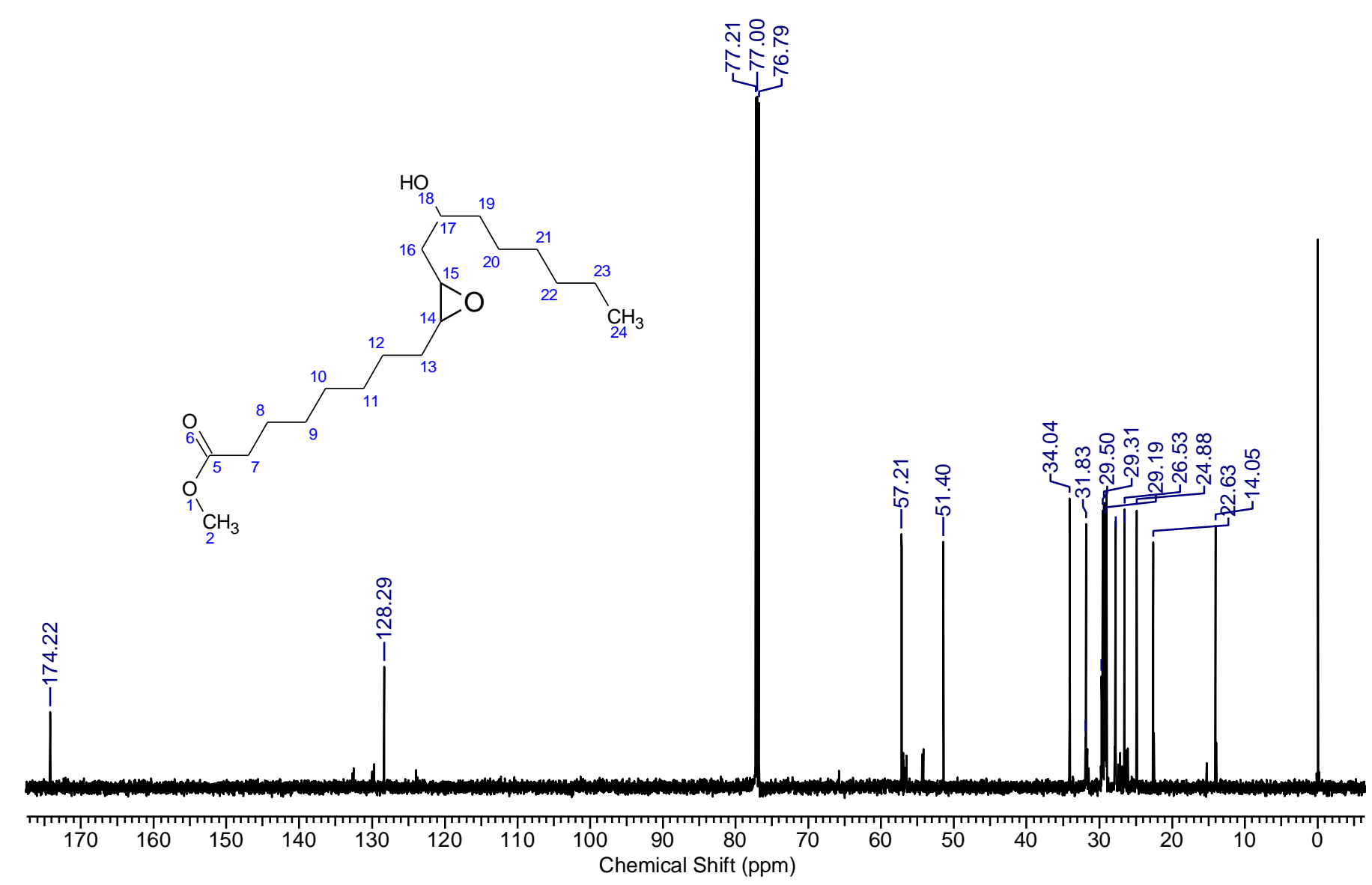

Anexo 27: Espectro de ressonância magnética nuclear de carbono $\left({ }^{13} \mathrm{C}\right.$ RMN $)$ do composto número 18. FONTE: Próprio autor. 

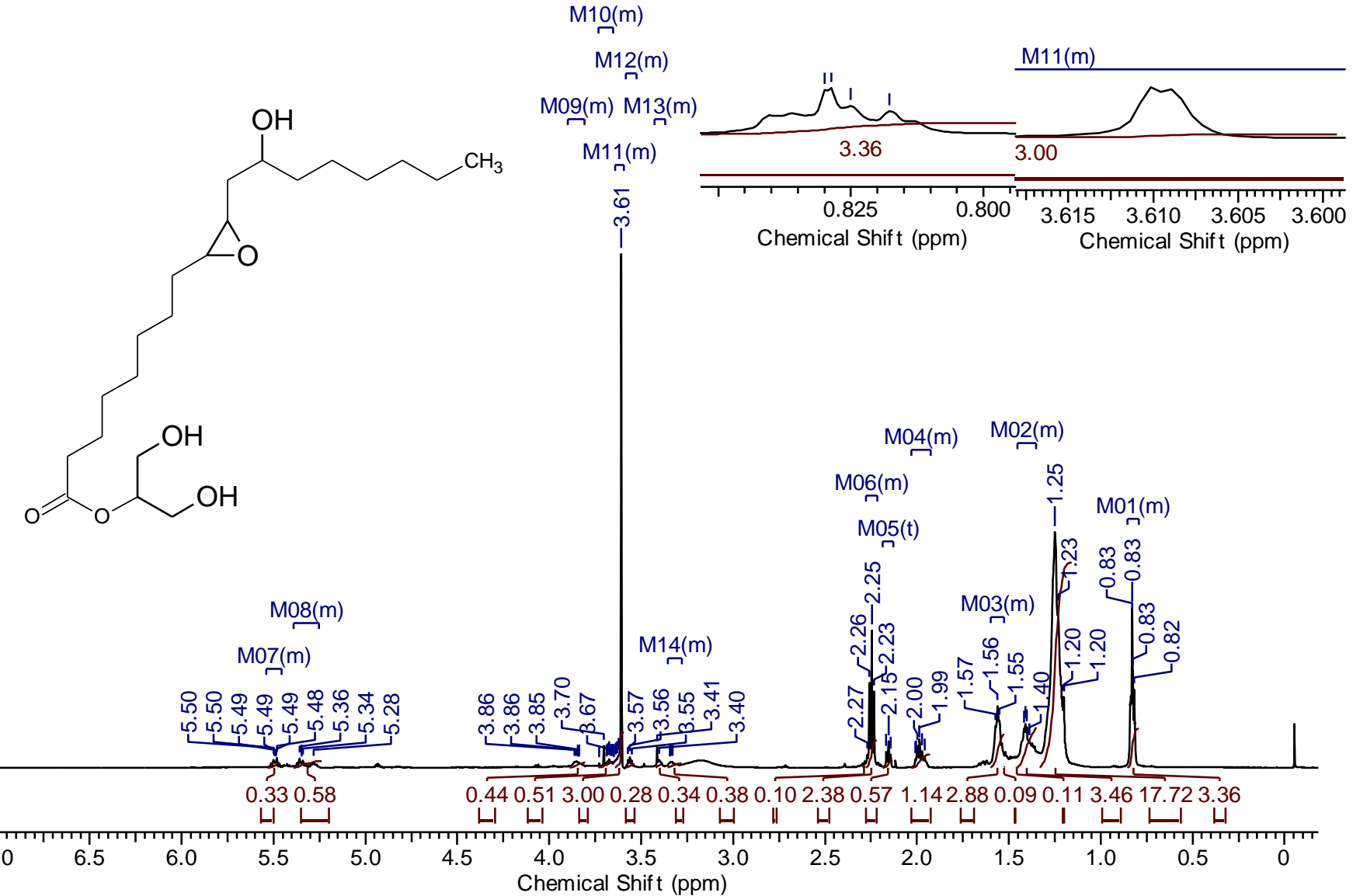

Anexo 28: Espectro de ressonância magnética nuclear de hidrogênio $\left({ }^{1} \mathrm{H}\right.$ RMN $)$ do composto número 19. FONTE: Próprio autor. 


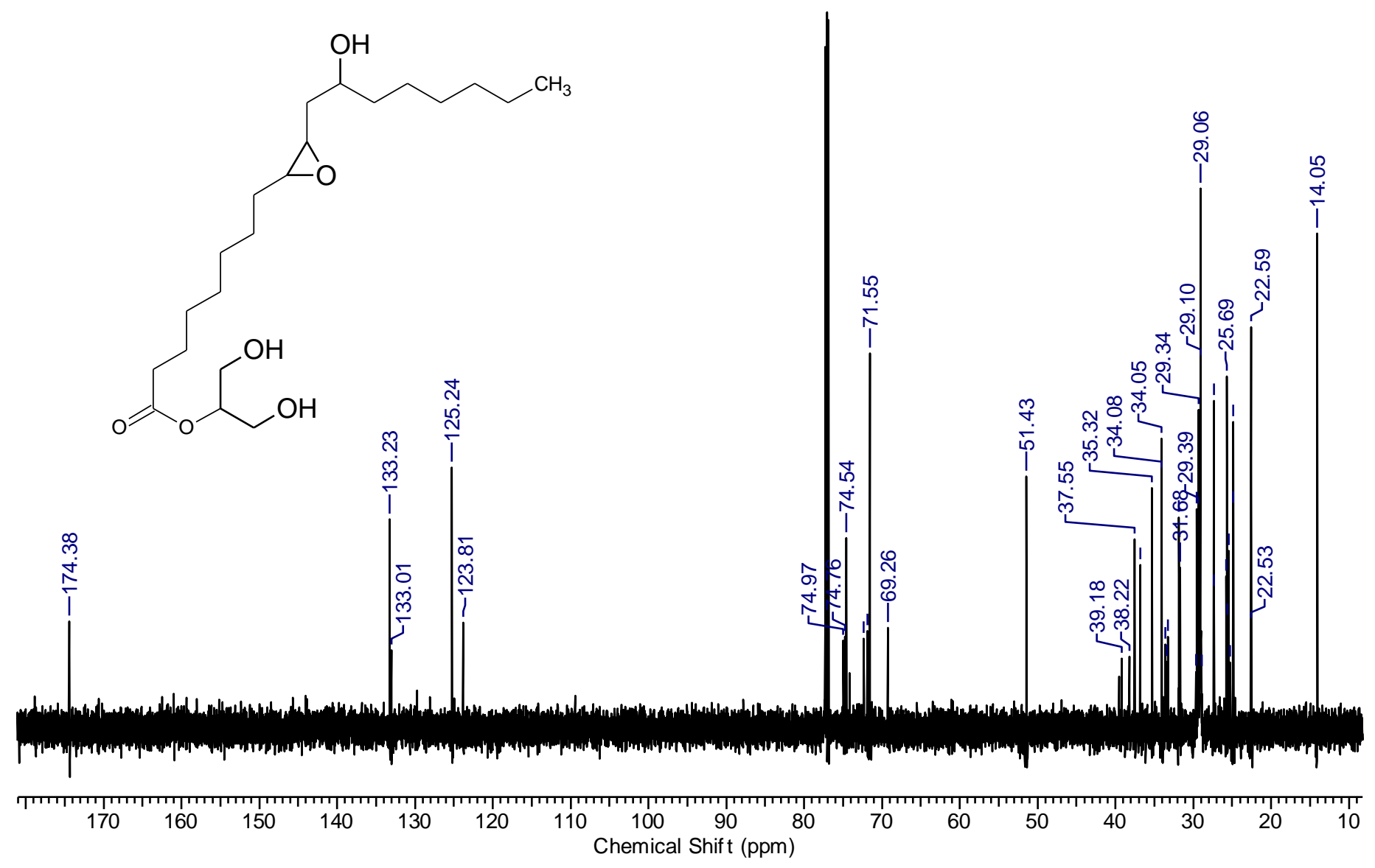

Anexo 29: Espectro de ressonância magnética nuclear de carbono $\left({ }^{13} \mathrm{C}\right.$ RMN $)$ do composto número 19. FONTE: Próprio autor. 


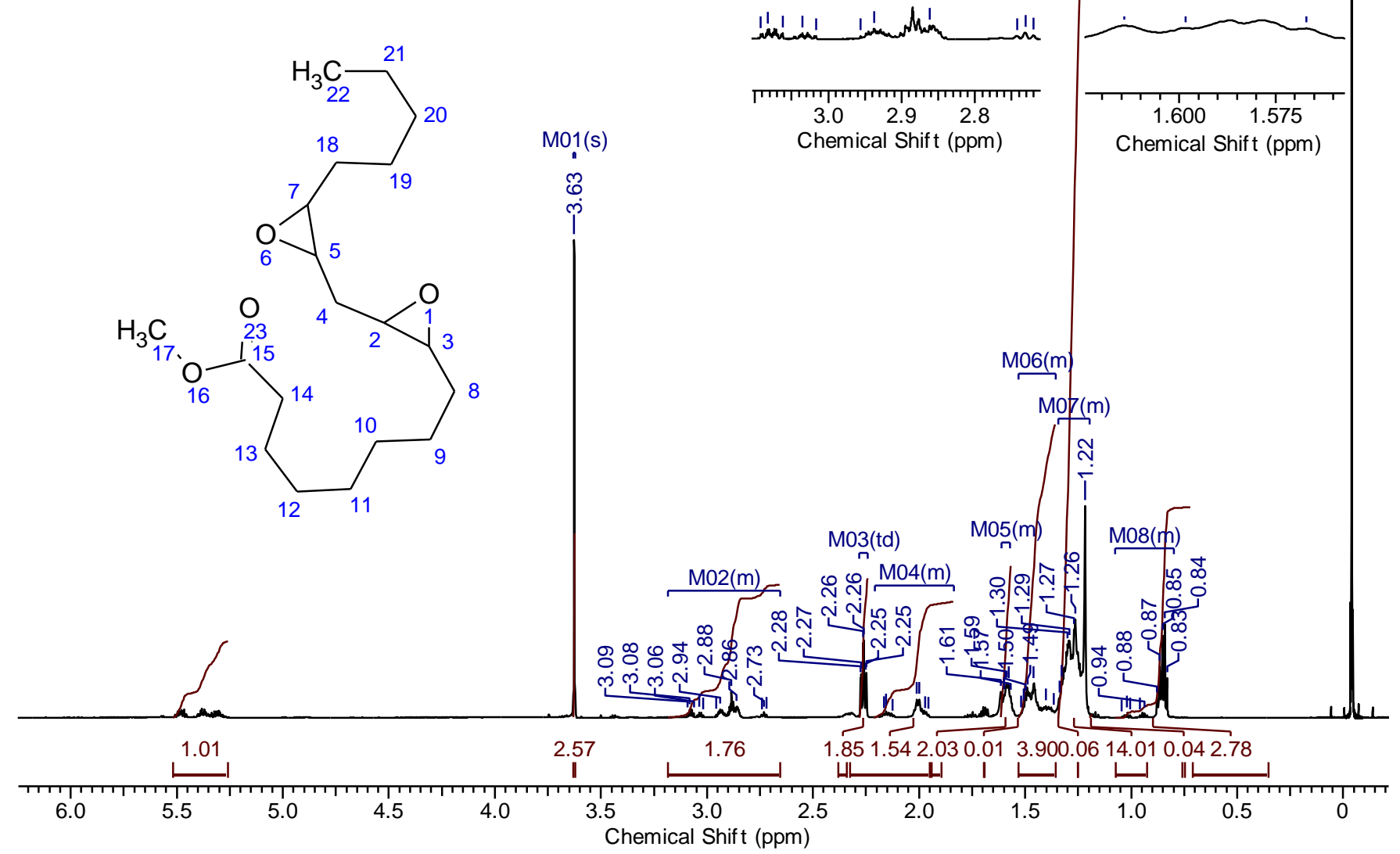

Anexo 30: Espectro de ressonância magnética nuclear de hidrogênio $\left({ }^{1} \mathrm{H}\right.$ RMN) do composto número 20. FONTE: Próprio autor. 


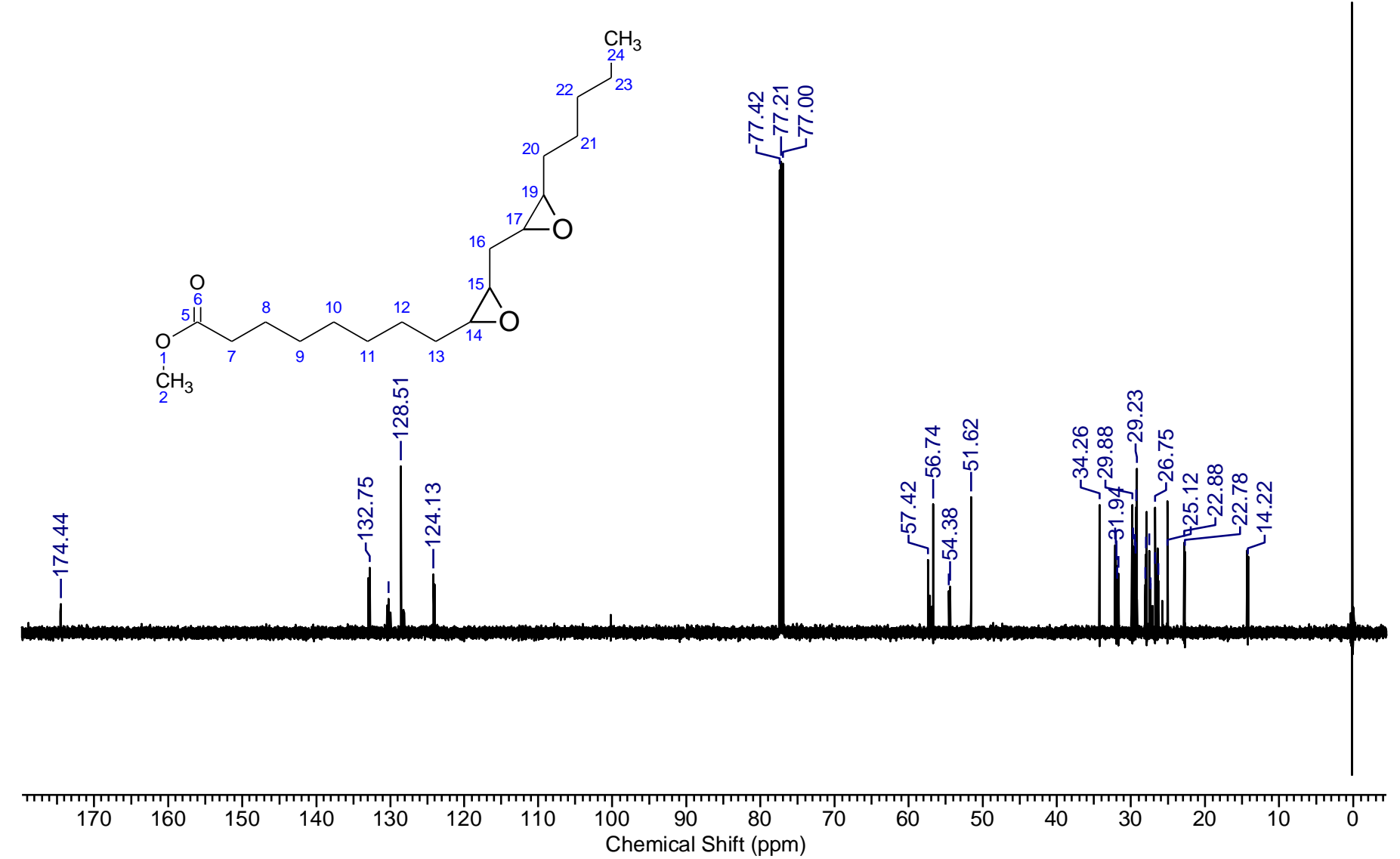

Anexo 31: Espectro de ressonância magnética nuclear de carbono $\left({ }^{13} \mathrm{C} R \mathrm{RMN}\right)$ do composto número 20. FONTE: Próprio autor. 


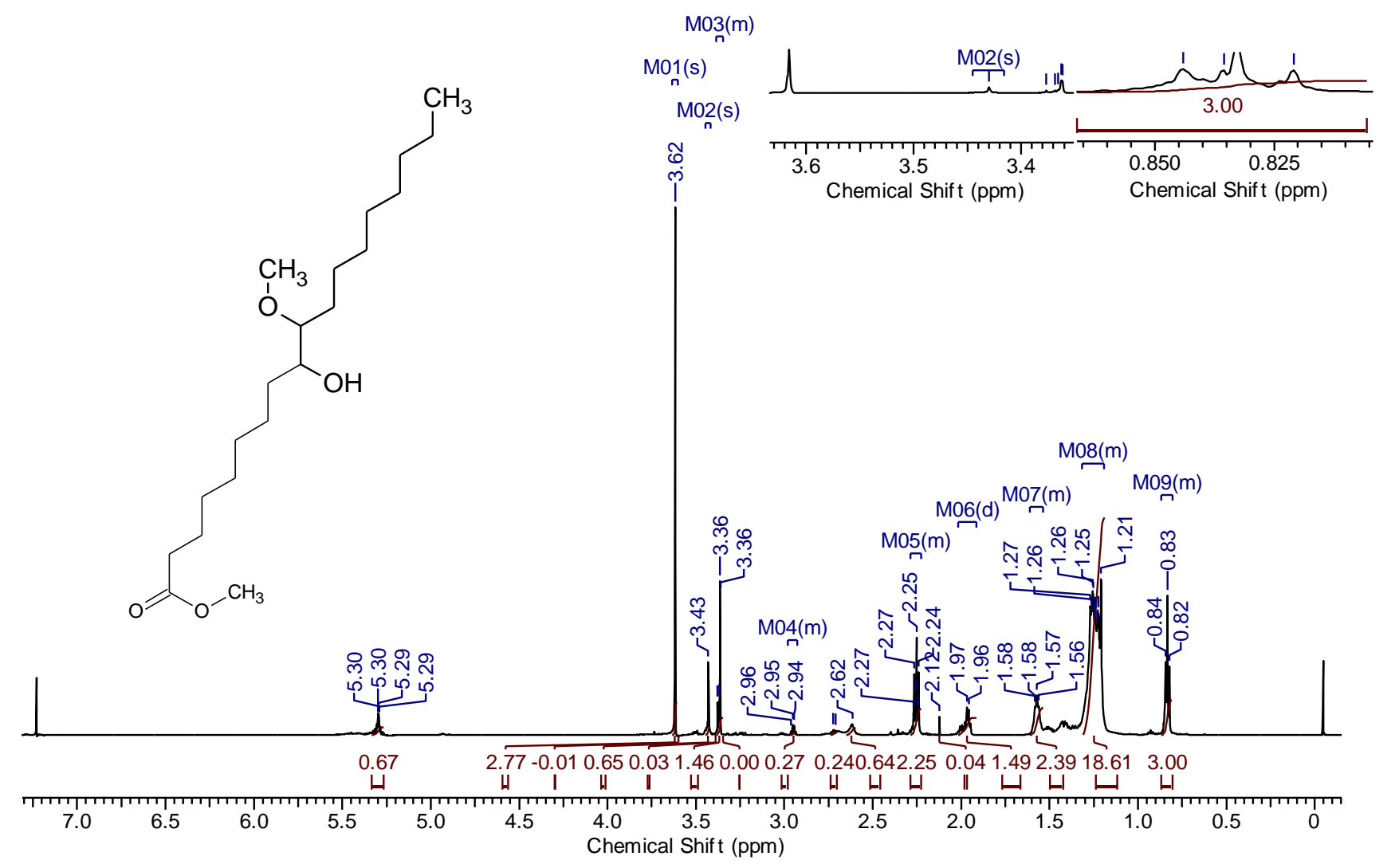

Anexo 32: Espectro de ressonância magnética nuclear de hidrogênio $\left({ }^{1} \mathrm{H}\right.$ RMN) do composto número 22. FONTE: Próprio autor. 


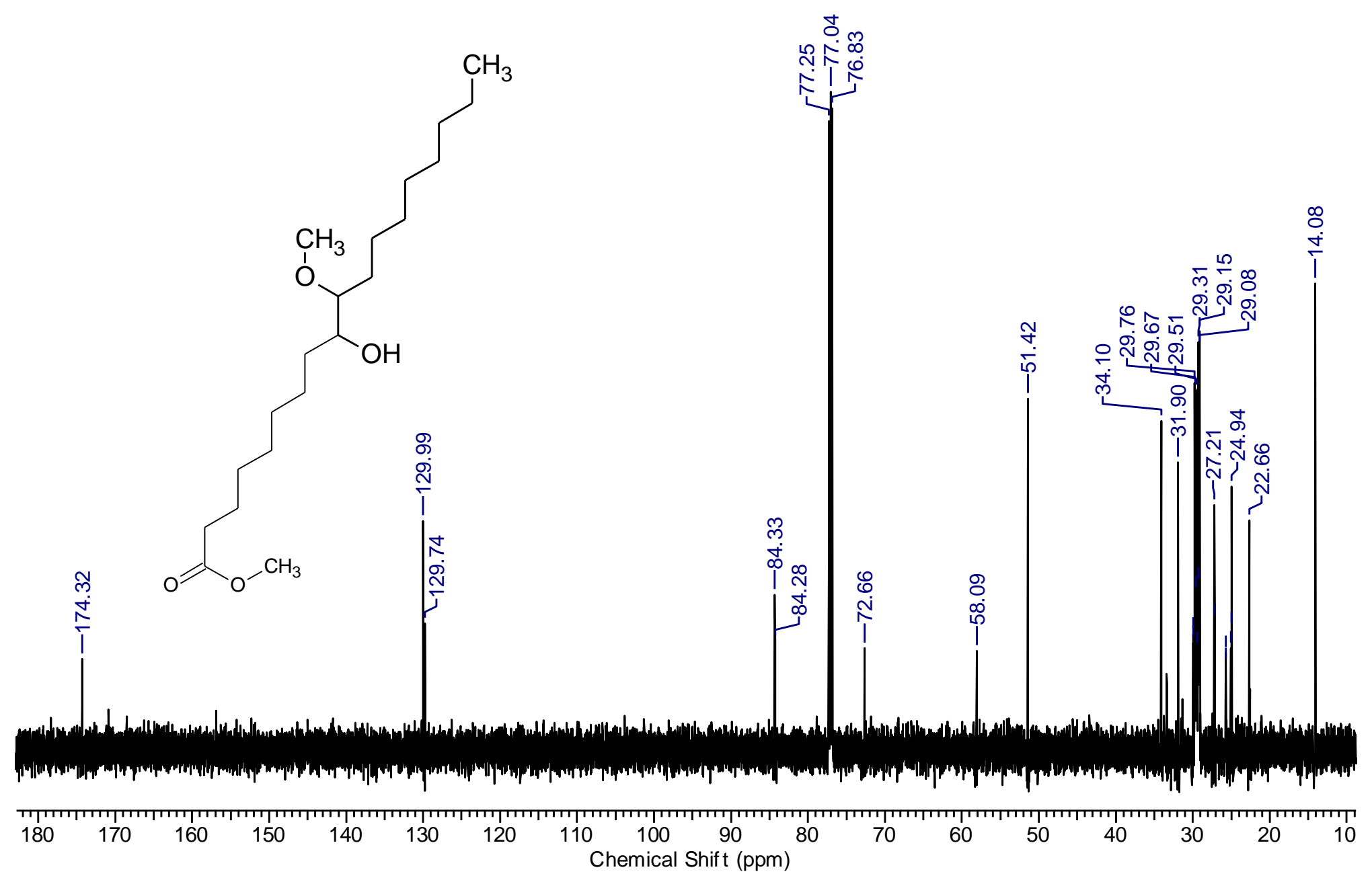

Anexo 33: Espectro de ressonância magnética nuclear de carbono $\left({ }^{13} \mathrm{C} \mathrm{RMN}\right)$ do composto número 22. FONTE: Próprio autor. 


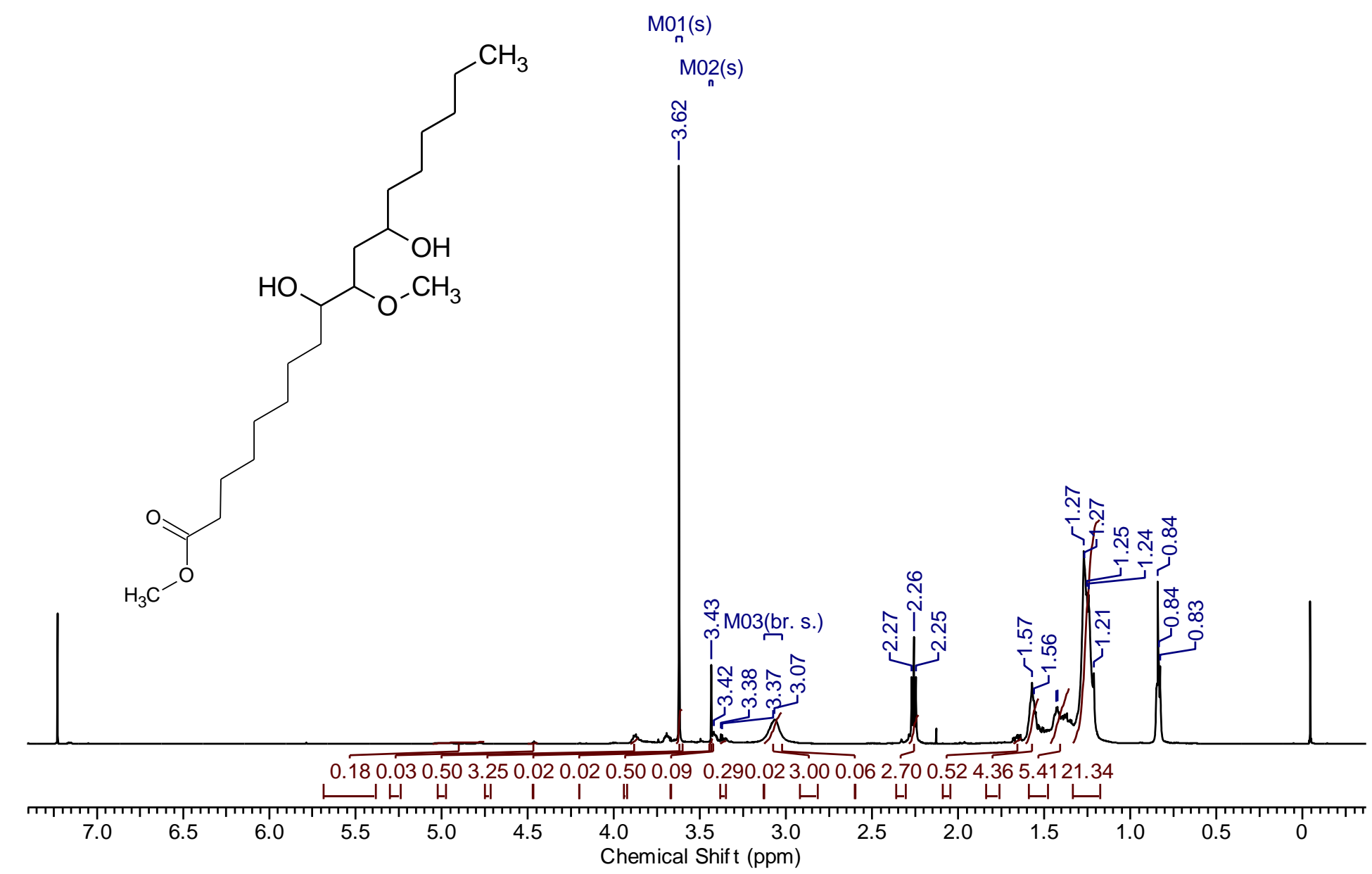

Anexo 34: Espectro de ressonância magnética nuclear de hidrogênio $\left({ }^{1} \mathrm{H}\right.$ RMN $)$ do composto número 23. FONTE: Próprio autor. 


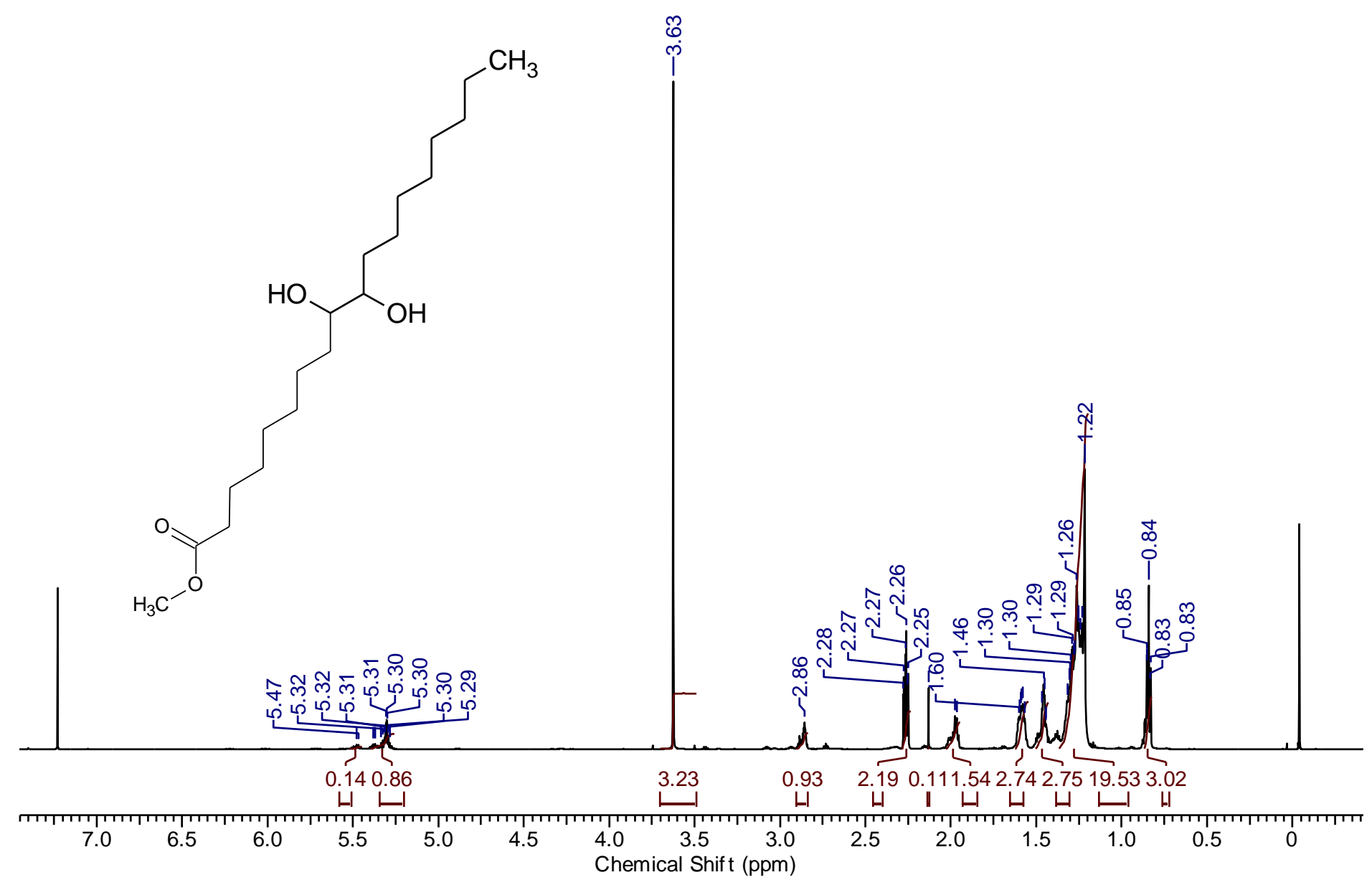

Anexo 35: Espectro de ressonância magnética nuclear de hidrogênio $\left({ }^{1} \mathrm{H}\right.$ RMN $)$ do composto número 25. FONTE: Próprio autor. 


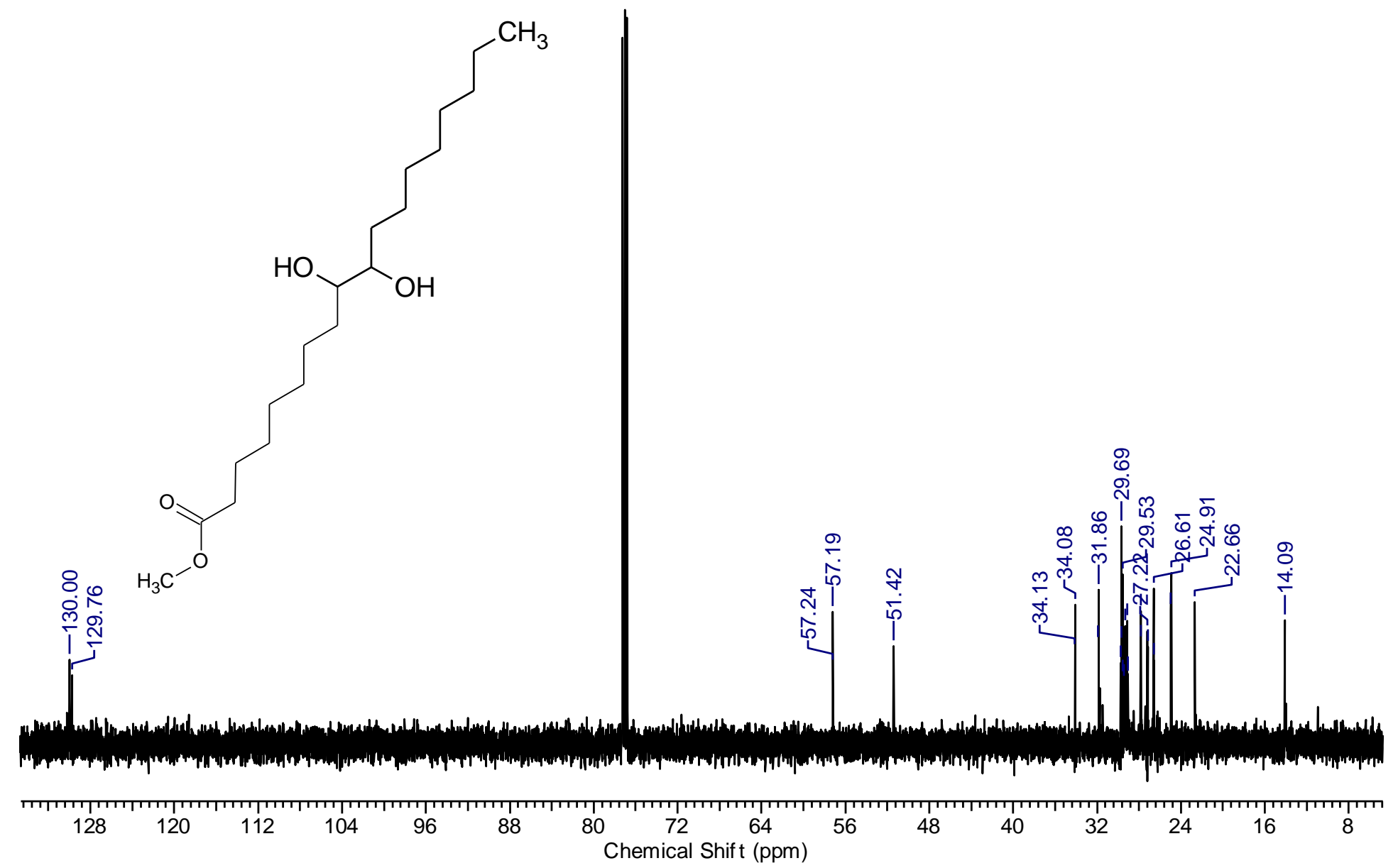

Anexo 36: Espectro de ressonância magnética nuclear de carbono $\left({ }^{13} \mathrm{C} \mathrm{RMN}\right)$ do composto número 25. FONTE: Próprio autor. 


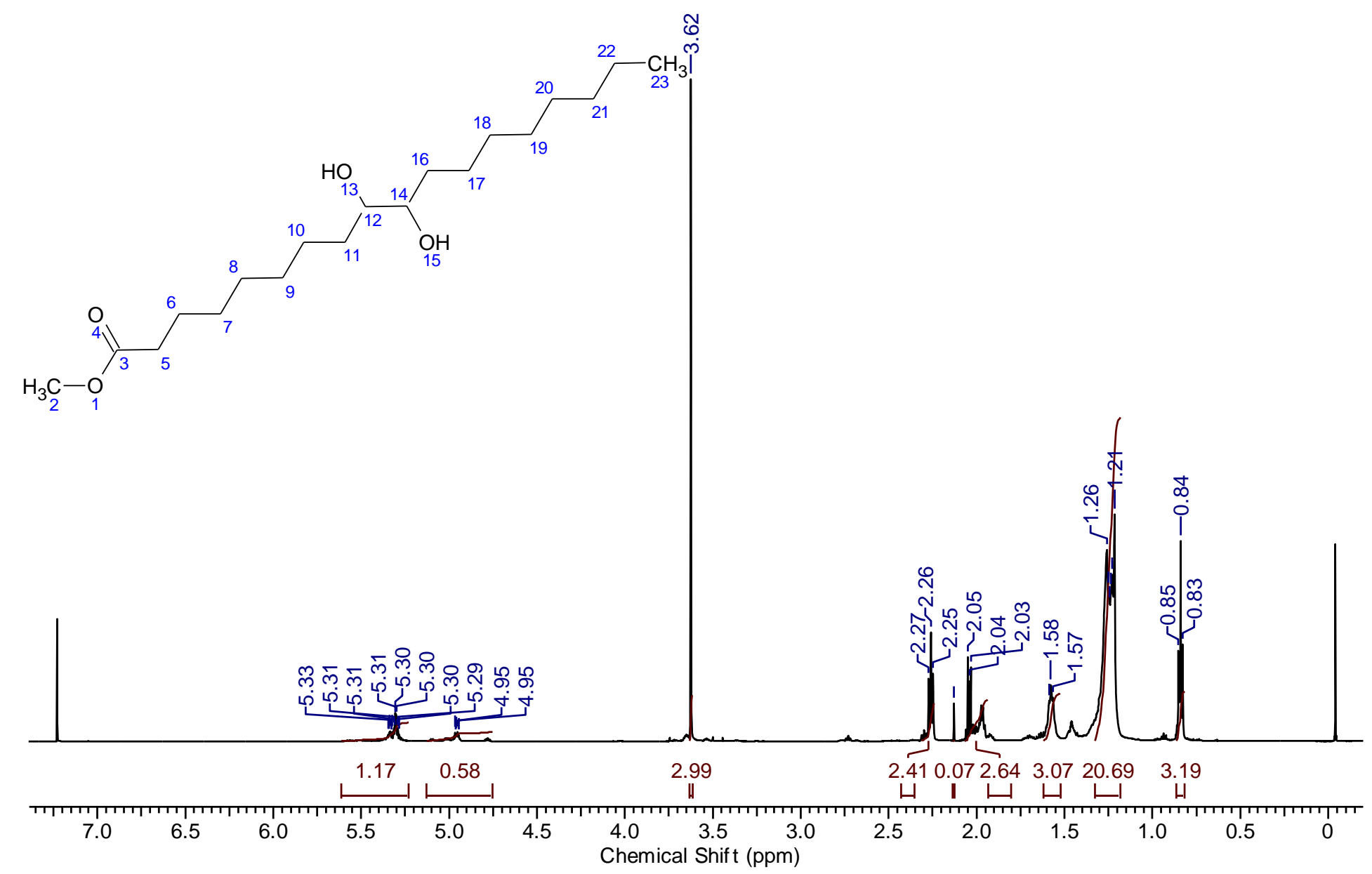

Anexo 37: Espectro de ressonância magnética nuclear de hidrogênio $\left({ }^{1} \mathrm{H}\right.$ RMN $)$ do composto número 26. FONTE: Próprio autor. 


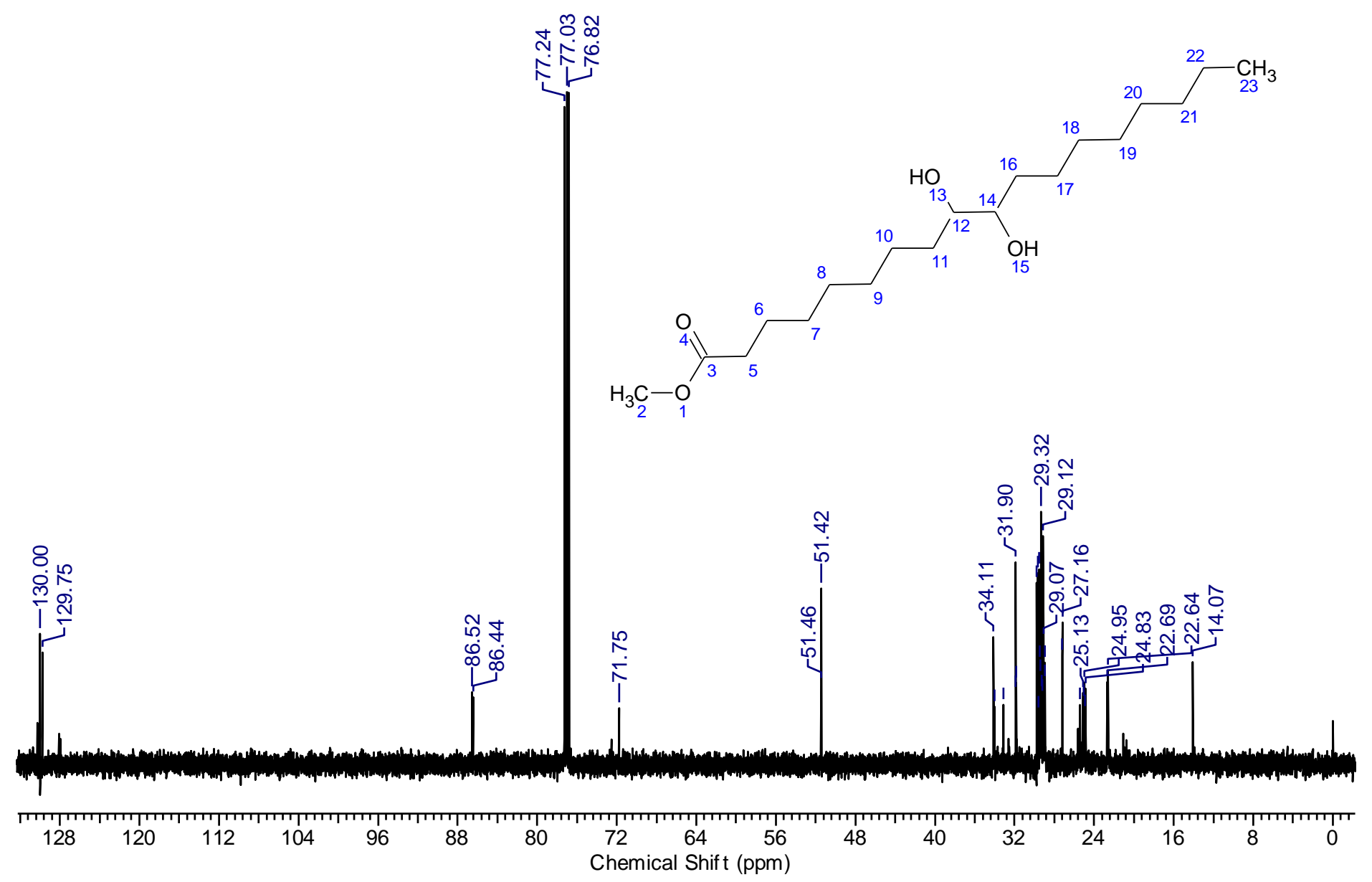

Anexo 38: Espectro de ressonância magnética nuclear de carbono $\left({ }^{13} \mathrm{C}\right.$ RMN $)$ do composto número 26. FONTE: Próprio autor. 

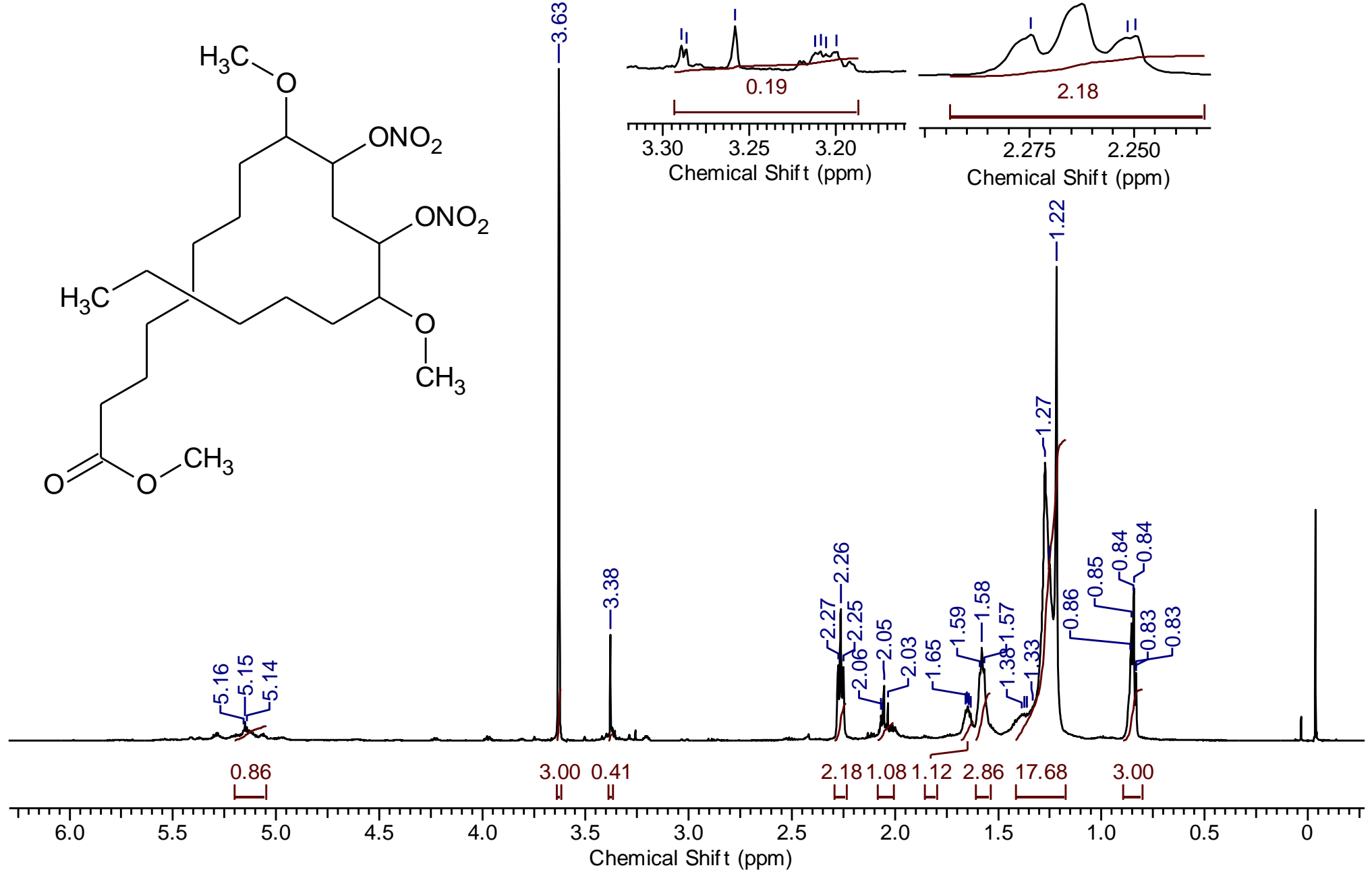

Anexo 39: Espectro de ressonância magnética nuclear de hidrogênio $\left({ }^{1} \mathrm{H}\right.$ RMN $)$ do composto número 42. FONTE: Próprio autor. 

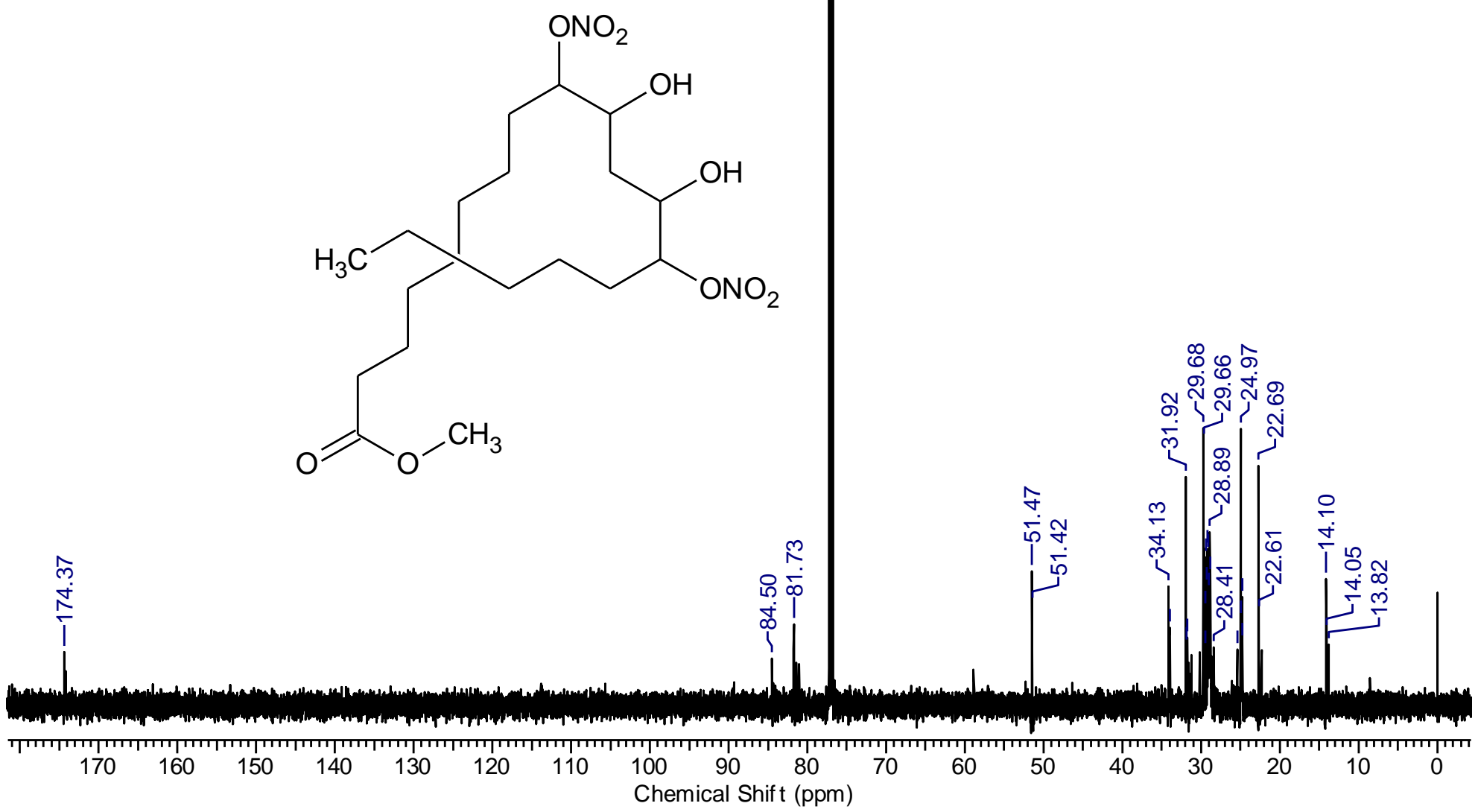

Anexo 40: Espectro de ressonância magnética nuclear de carbono $\left({ }^{13} \mathrm{C}\right.$ RMN $)$ do composto número 42. FONTE: Próprio autor. 


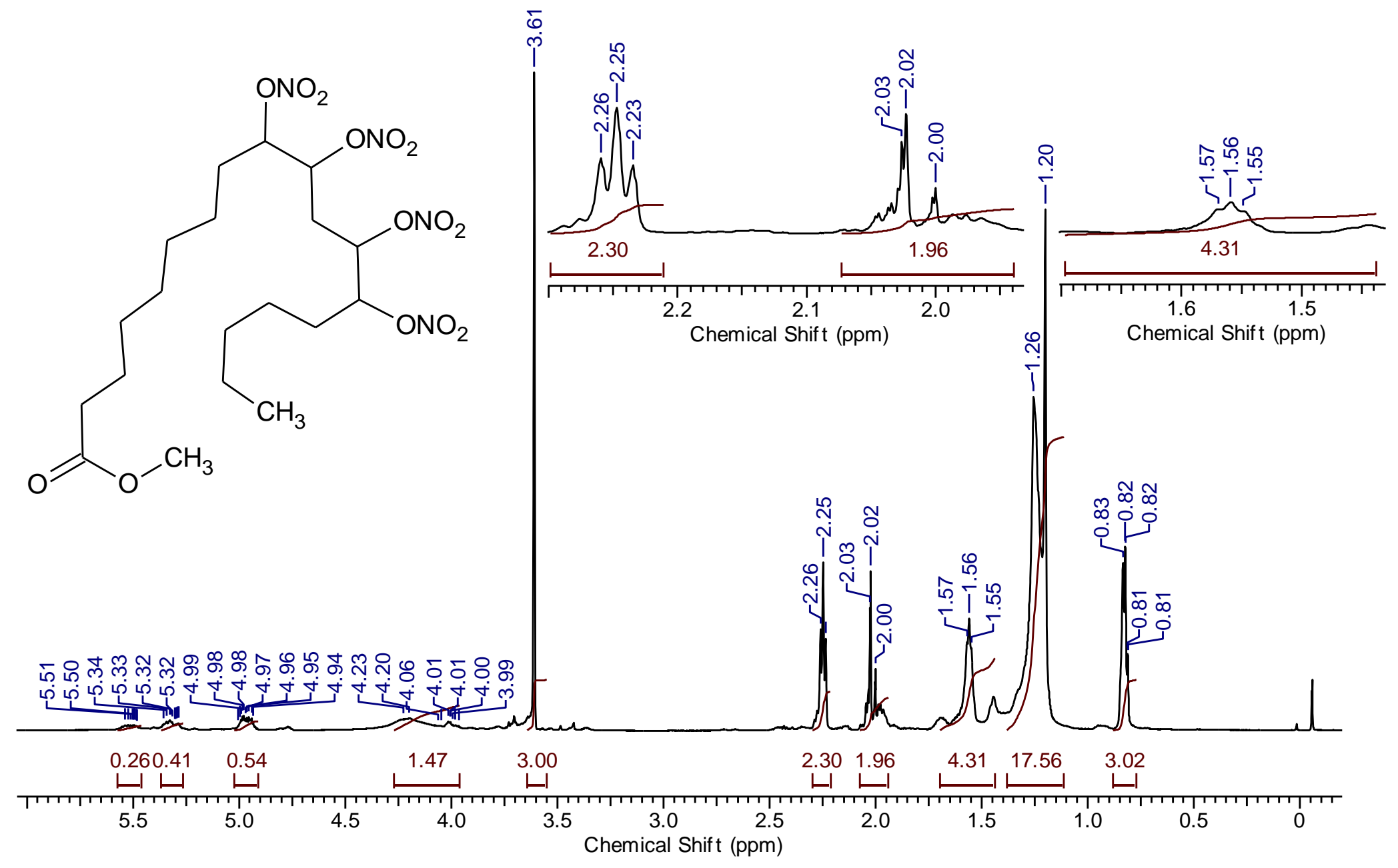

Anexo 41: Espectro de ressonância magnética nuclear de hidrogênio $\left({ }^{1} \mathrm{H}\right.$ RMN $)$ do composto número 43. FONTE: Próprio autor. 

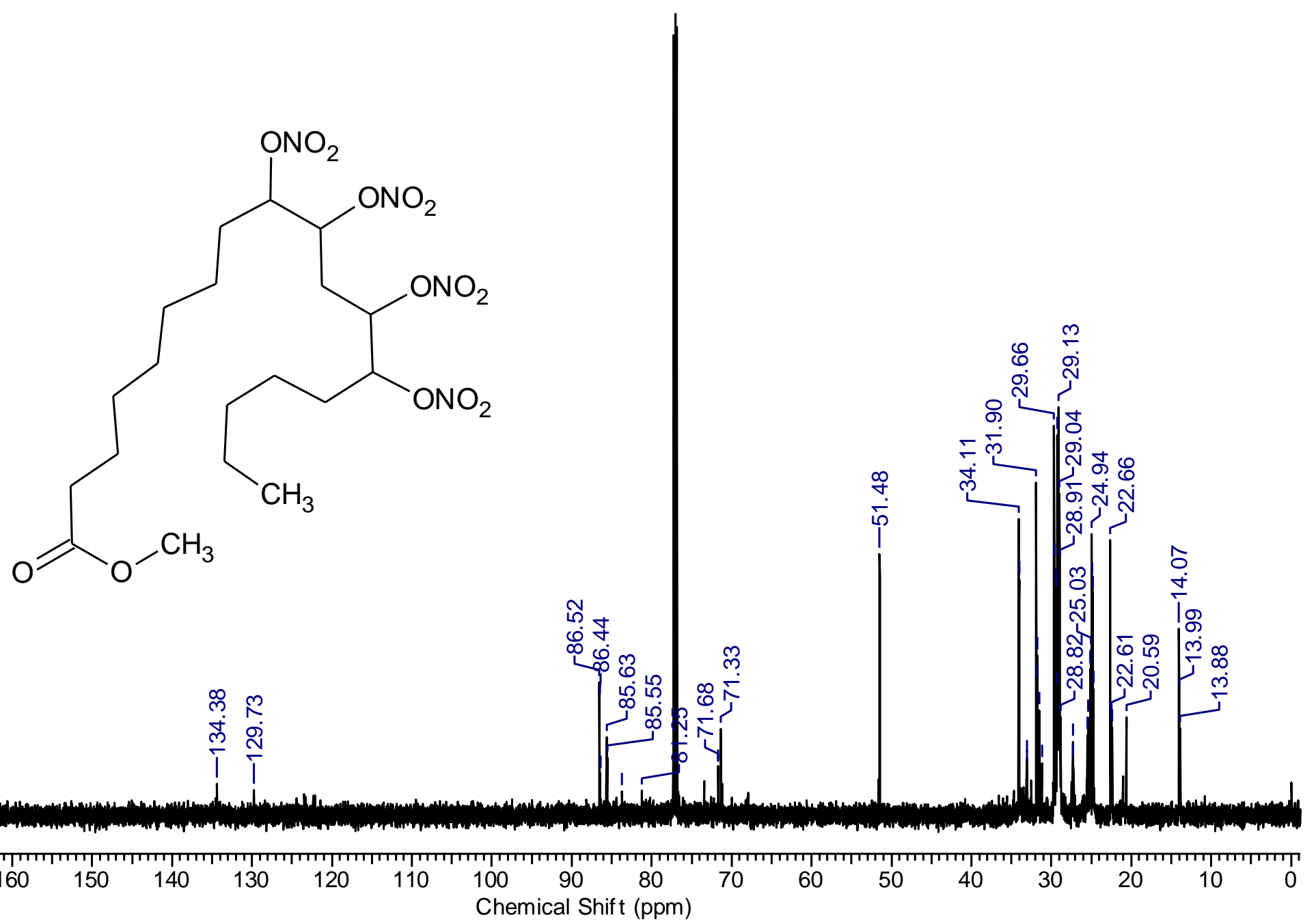

Anexo 42: Espectro de ressonância magnética nuclear de carbono $\left({ }^{13} \mathrm{C}\right.$ RMN $)$ do composto número 43. FONTE: Próprio autor. 

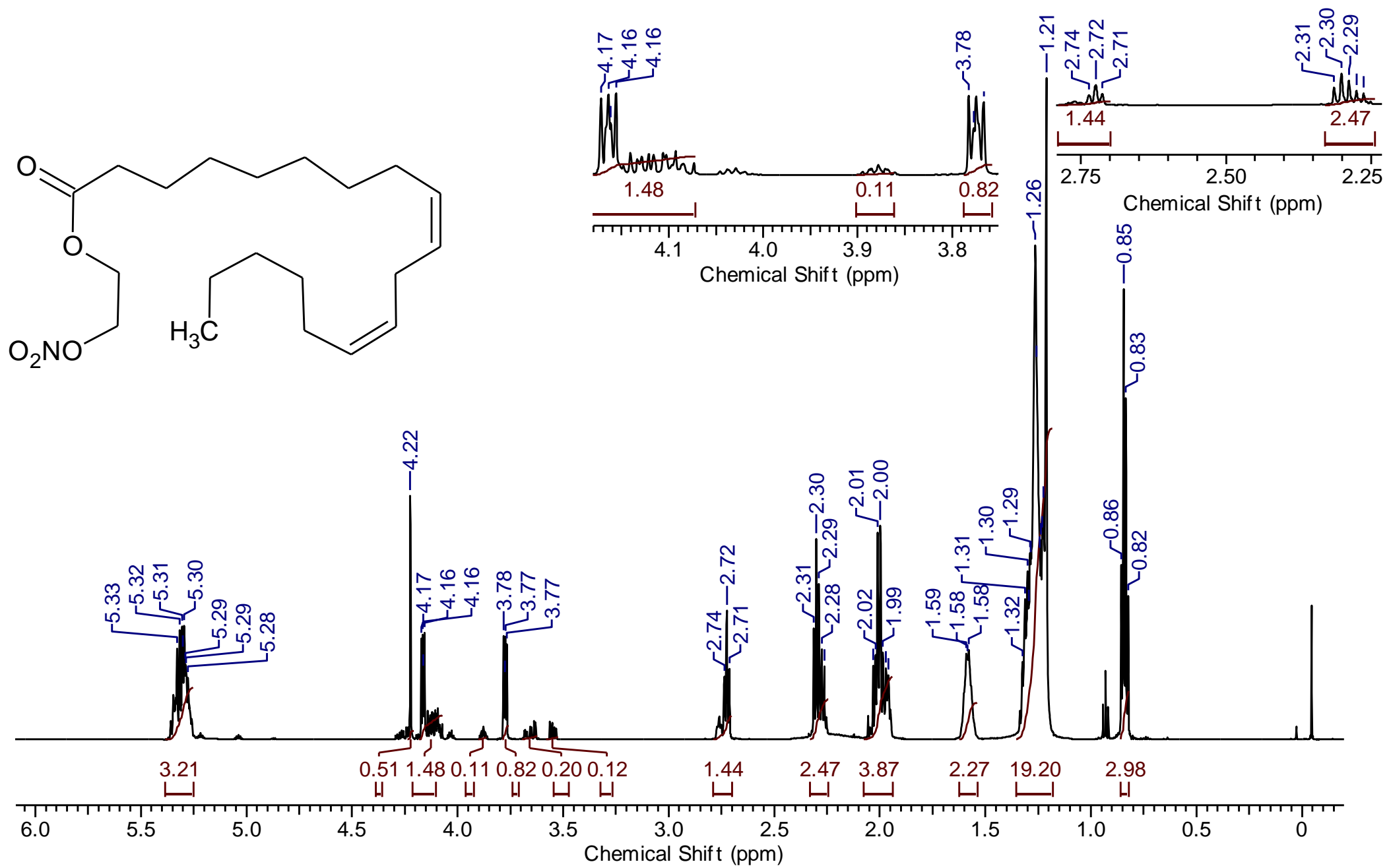

Anexo 43:Espectro de ressonância magnética nuclear de hidrogênio $\left({ }^{1} \mathrm{H}\right.$ RMN $)$ do composto número 44. FONTE: Próprio autor. 


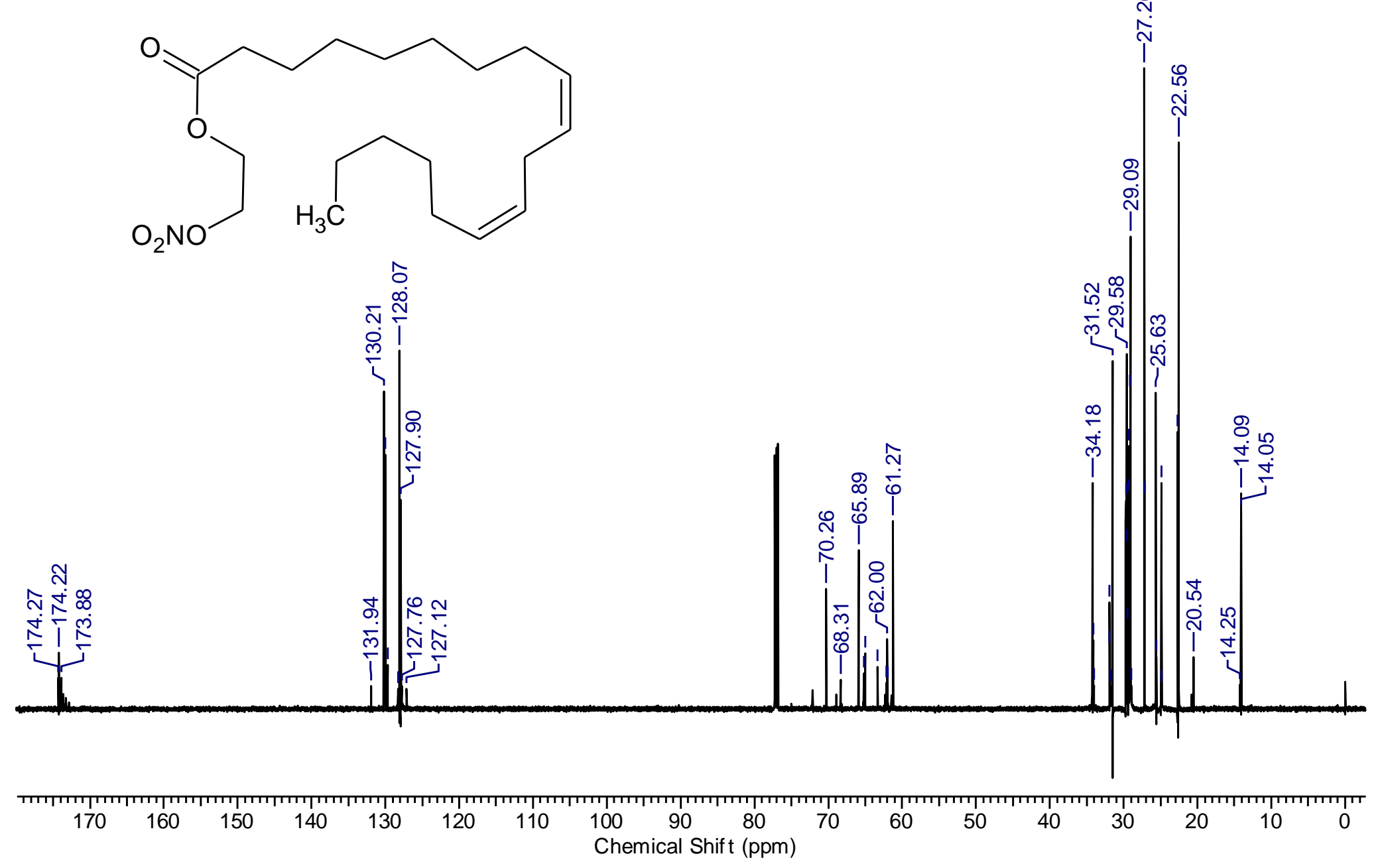

Anexo 44: Espectro de ressonância magnética nuclear de carbono $\left({ }^{13} \mathrm{C}\right.$ RMN $)$ do composto número 44. FONTE: Próprio autor. 


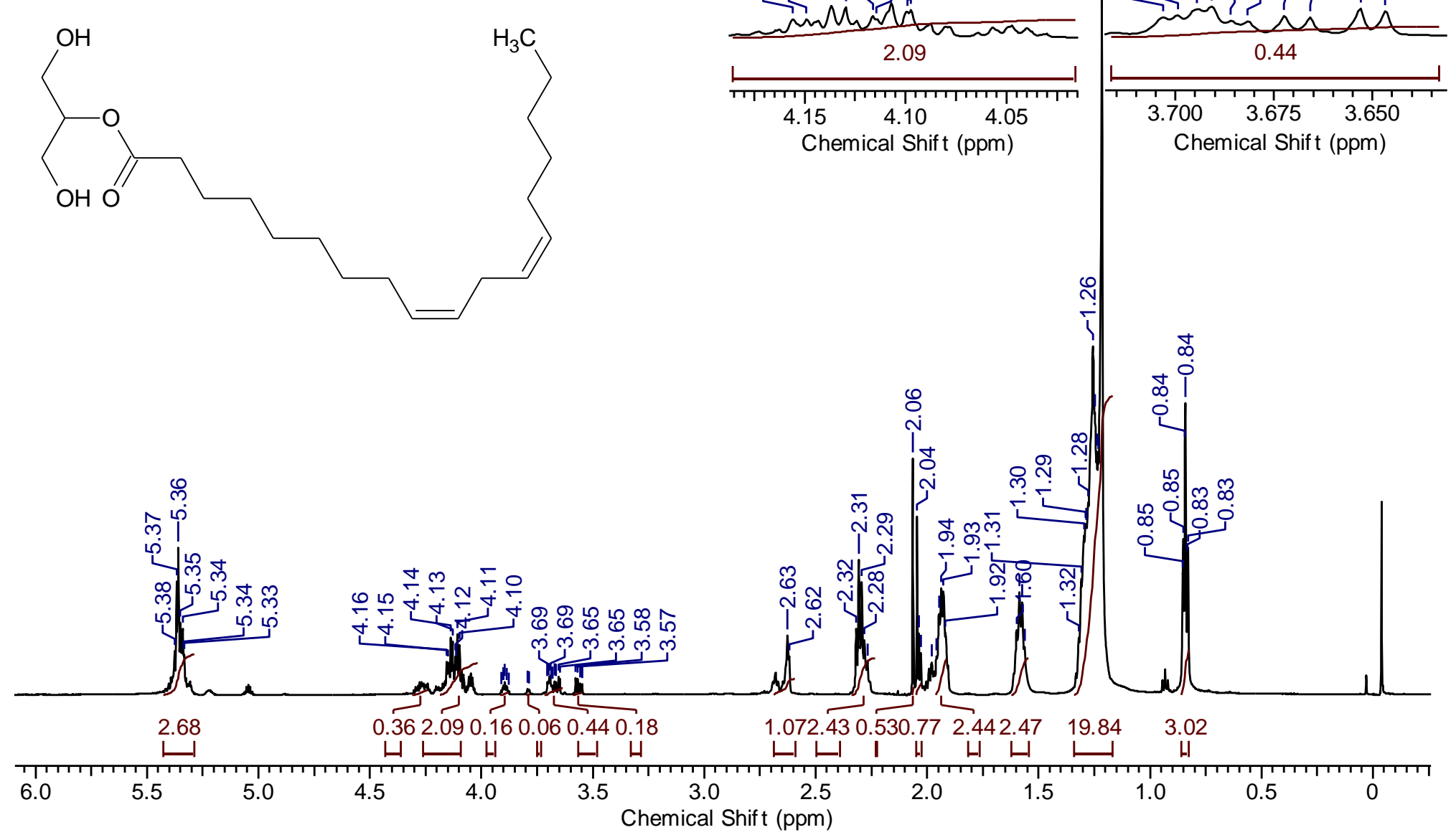

Anexo 45: Espectro de ressonância magnética nuclear de hidrogênio $\left({ }^{1} \mathrm{H}\right.$ RMN) do composto número 45. FONTE: Próprio autor. 


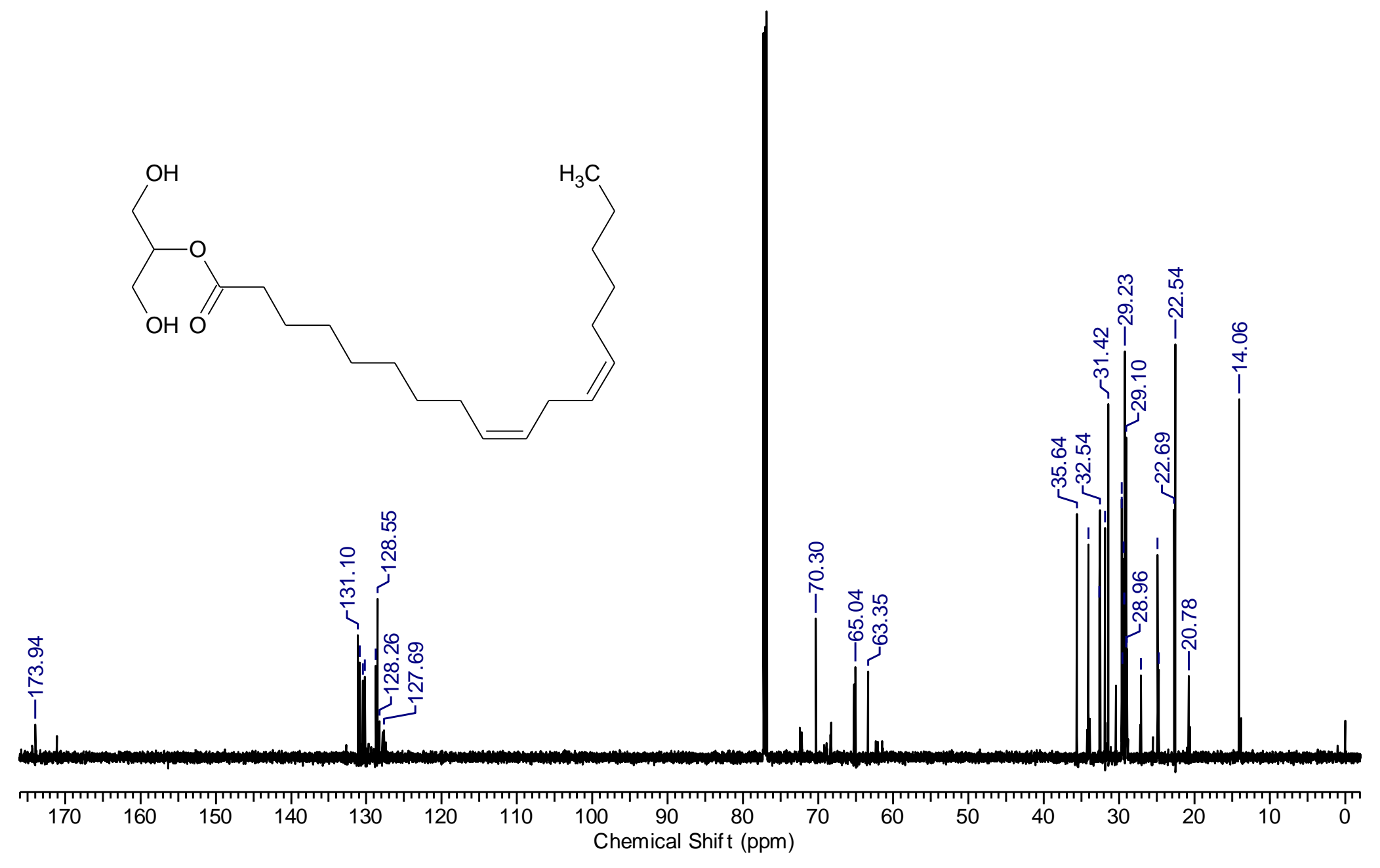

Anexo 46: Espectro de ressonância magnética nuclear de carbono $\left({ }^{13} \mathrm{C} \mathrm{RMN}\right)$ do composto número 45. FONTE: Próprio autor. 